\title{
RELIGIOUS MOTIVATION AND THE ORIGINS OF BUDDHISM
}

\begin{abstract}
Why did North Indian people from the fifth century BC choose to leave the world and join the sect of the Buddha? Were there common themes in the religious motivation of these early Buddhists? Is it possible to illuminate motivational themes using social psychology?

This is the first book to apply the insights of social psychology in order to understand the religious motivation of the people who constituted the early Buddhist community. It also addresses the more general and theoretically controversial question of how world religions came into being, by focusing on the conversion process of the individual believer.
\end{abstract}

Torkel Brekke holds a DPhil in Oriental Studies from the University of Oxford on the politics of religious identity in colonial South Asia. He is currently a research fellow funded by the Norwegian Research Council. His main research interest is the interaction between religious ideas and processes of political and historical change. 


\section{General Editors:}

\section{Charles S. Prebish and Damien Keown}

The RoutledgeCurzon Critical Studies in Buddhism Series is a comprehensive study of the Buddhist tradition. The series explores this complex and extensive tradition from a variety of perspectives, using a range of different methodologies.

The series is diverse in its focus, including historical studies, textual translations and commentaries, sociological investigations, bibliographic studies, and considerations of religious practice as expressions of Buddhism's integral religiosity. It also presents material on modern intellectual historical studies, including the role of Buddhist thought and scholarship in a contemporary, critical context and in the light of current social issues. The series is expansive and imaginative in scope, spanning more than two and a half millennia of Buddhist history. It is receptive to all research works that inform and advance our knowledge and understanding of the Buddhist tradition.

THE REFLEXIVE NATURE OF AWARENESS Paul Williams

BUDDHISM AND HUMAN RIGHTS

Edited by Damien Keown, Charles Prebish and Wayne Husted

ALTRUISM AND REALITY

Paul Williams

WOMEN IN THE FOOTSTEPS OF THE BUDDHA Kathryn R. Blackstone

THE RESONANCE OF EMPTINESS

Gay Watson

IMAGING WISDOM

Jacob N. Kinnard

AMERICAN BUDDHISM

Edited by Duncan Ryuken Williams and Christopher Queen

PAIN AND ITS ENDING

Carol S. Anderson 
THE SOUND OF LIBERATING TRUTH

Edited by Sallie B. King and Paul O. Ingram

BUDDHIST THEOLOGY

Edited by Roger R. Jackson and John J. Makransky

EMPTINESS APPRAISED

David F. Burton

THE GLORIOUS DEEDS OF PŪRNA

Joel Tatelman

CONTEMPORARY BUDDHIST ETHICS

Edited by Damien Keown

INNOVATIVE BUDDHIST WOMEN

Edited by Karma Lekshe Tsomo

TEACHING BUDDHISM IN THE WEST

Edited by V. S. Hori, R. P. Hayes and J. M. Shields

EMPTY VISION
David L. McMahan

SELF, REALITY AND REASON IN

TIBETAN PHILOSOPHY

Thupten Jinpa

RELIGIOUS MOTIVATION AND THE

ORIGINS OF BUDDHISM

Torkel Brekke 



\title{
RELIGIOUS \\ MOTIVATION AND \\ THE ORIGINS OF BUDDHISM
}

\author{
A social-psychological \\ exploration of the origins of a \\ world religion
}

Torkel Brekke

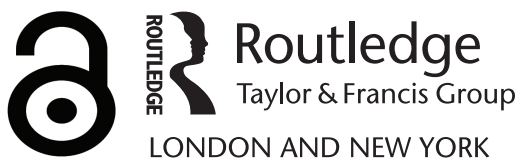


First published 2002 by RoutledgeCurzon

Published 2017 by Routledge

2 Park Square, Milton Park, Abingdon, Oxon OX14 4RN

711 Third Avenue, New York, NY 10017, USA

Routledge is an imprint of the Taylor \& Francis Group, an informa business

\section{Copyright @ 2002 Torkel Brekke}

Typeset in Times by Prepress Projects Ltd, Perth, Scotland

The Open Access version of this book, available at www.tandfebooks.com, has been made available under a Creative Commons Attribution-Non

Commercial-No Derivatives 4.0 license.

British Library Cataloguing in Publication Data

A catalogue record for this book is available from the British Library

Library of Congress Cataloging in Publication Data

A catalog record for this book has been requested

ISBN 978-0-7007-1683-8 (hbk)

ISBN 978-0-7007-1684-5 (pbk) 


\section{CONTENTS}

Acknowledgements ix

Introduction 1

1 The historical value of the Khandhaka of the Vinaya Pitaka 5

2 Religious motivation and the relationship between the early Samgha and the laity

3 Religious motivation and the theme of conversion in Buddhism

4 Social psychology and the religious motivation of the early Buddhists

5 Religious motivation and the role of fear

6 Religious motivation and the merit of giving

Notes

Bibliography

Index 



\section{ACKNOWLEDGEMENTS}

The articles on which this book is based were written between 1996 and 1999. During this time I was a doctoral student at the University of Oxford, writing a thesis on religious change in South Asia during the colonial period under the supervision of Professor Richard Gombrich. His writings are a constant source of inspiration. I have been lucky to have studied under generous and encouraging teachers both at the University of Oxford and at the University of Oslo. I wish to thank Professor Jens Braarvig and Professor Georg von Simson, who taught me Sanskrit and Pāli. An earlier version of the second chapter of this book was written as an MPhil thesis under their supervision in 1995. As all my teachers must have realized, my greatest problem as a student was that I tried to do too many things at the same time. This book, which attempts to say something both about Buddhism and about the psychology of religion, is probably symptomatic.

I would like to thank Professors Charles Prebish and Damien Keown, the editors of the series Critical Studies in Buddhism at Curzon Press, for their positive response when I approached them in the winter of 2000/1 with my proposal for this book. I am also grateful to Jonathan Price, chief editor at Curzon Press, for his constant optimism regarding this and other projects.

I am indebted to the publishers who authorized the use of articles that had appeared in their journals. The details of these previous publications are given in the introduction below. During the years when the research for this book was carried out my work was generously financed by the Norwegian Research Council.

As always, I owe many thanks to my family - Margrete, Kristian and Iris - for their patience and support. This book is dedicated to my friend and mentor Chung Lu Tsen. 



\section{INTRODUCTION}

The aim of this book is to explore whether and how a socialpsychological approach may further our understanding of religious motivation in Buddhism, primarily early Buddhism, that is Buddhism at the time when the Buddha or his direct disciples still lived. The basic questions that it seeks to answer are:

- Why did people choose to join the Buddha?

- Why did they become monks or nuns?

- Were there common themes in the religious motivation of the early Buddhists?

- Is it possible to illuminate these motivational themes by applying the theoretical insights of social psychology?

In general terms, this is a book about the social psychology of religion and, in more specific terms, it is a book about religious motivation in Buddhism. I believe that in order to understand why a religion comes into being, and why it succeeds in becoming a world religion, we should devote more attention to the religious motivation of individuals than is usual in the study of religious history. Needless to say, in historical studies it is often difficult, or even impossible, to say anything about cognitive processes of individuals. However, when there is a possibility, we should try to understand the motivation of the people who initiate change. Of course, there are a number of problems connected with a socialpsychological study of Buddhism. I will discuss some of these problems in the book, but there will still be many ways to criticize this type of study both from the angle of philology and from the angle of social psychology. The kind of approach that I have taken here is not very common and it involves the risk of making mistakes in several academic fields at the same time. 
The book consists of six chapters, each of which has previously appeared elsewhere. They are all attempts to illuminate the religious motivation of Buddhists and they share the fundamental approach of social psychology. Chapter 1 is based on the following article: 'The Skandhaka of the Vinaya Pitaka and its Historical Value', Wiener Zeitschrift für die Kunde Südasiens und Archiv für Indische Philosophie, XLII, 1998: 23-40. This chapter is an argument for the use of the Khandhaka section of the Vinaya Pitaka in the study of the origins of Buddhism. The argument is that these texts are likely to be very close to the life of the Buddha and therefore their historical value is greater than previously assumed. The other chapters of the book take the Khandhakas as a main source, and Chapter 1 therefore serves as a legitimation for this approach as well as an introduction to the most important source.

In the concluding pages of his survey of Vinaya literature, Prebish wrote that the character of the new publications on this literature those of the 1990s - is interpretive rather than simply informative. 'It is only now that we can say that Vinaya study has come of age', he wrote. ${ }^{1}$ Although religious motivation is my subject here, it is my hope that this book may be seen as a small contribution to the interpretive study of the Vinaya.

Chapter 2 is based on the article 'The Early Samgha and the Laity', Journal of the International Association of Buddhist Studies, 20 (2), 1997: 7-33. This chapter uses the Khandhakas, as well as selected texts from the Sutta Pitaka, to argue that the Buddhist Samgha went through some very fundamental changes in its earliest stages as a response to its peculiar relationship to the laity. In it I also apply some basic concepts from the social psychology of religion, such as extrinsic and intrinsic motivation, to illuminate the relationship between monks and lay people and argue that the Samgha moved from a conversionist to an introversionist relationship to the world.

Chapter 3 is based on the article 'Conversion in Buddhism?', in Conversion in Indian Religions, edited by Rowena Robinson and Satianathan Clarkes (Delhi: Oxford University Press, forthcoming). This chapter discusses the appropriateness of terms such as conversion in the context of early Buddhism. Is the very idea of conversion, a sudden realization of truth, too closely linked to the Christian tradition to be applicable to other cultures? The basic argument of this chapter is that Buddhist texts display a certain ambiguity when they describe the conversion process of the early 
members of the Samgha. In the paradigmatic story of the Buddha, and other similar stories, we are presented with a view that conversion is a gradual process of realization, whereas in a number of other instances early Buddhists experience a sudden change that is more akin to the Christian idea of conversion. I argue that this paradox is solved if we realize that sudden conversions, or conversions proper, take place mainly when people leave the life of householder and enter one of the religious movements of the period, whereas individuals who are already part of the milieu of mendicants go in and out of the different sects without necessarily experiencing a personal crisis.

Chapter 4 is based on the article 'Contradiction and the Merit of Giving in Indian Religions', Numen, International Review for the History of Religion, 45, 1998: 287-320. In this chapter I focus on the bonds created between the monks and lay people through donations. While Chapter 2 looks at how the early Samgha changed because of its relationship to the laity, this chapter takes a broader view of the role of giving in Indian religions, and Buddhism in particular. The gift has been an important focus of research on Indian sociology and religion. However, almost all research has been confined to the Hindu tradition. I believe that a study of the practice of giving to the Samgha can illuminate important aspects of the religious motivation of Buddhism.

Chapter 5 is based on the article 'The Role of Fear in Indian Religions with Special Reference to Buddhism', Journal of Indian Philosophy, 27, 1999: 439-67. This chapter continues the socialpsychological search for the motivation of the early Buddhists by looking at the role of fear. Fear is an important theme in Indian religions and is encountered in the literature of many different traditions of the sub-continent. However, the role of fear has received no attention from scholarship either in indology or in the history of religions. In this chapter I attempt to illuminate the role of fear in religious motivation and in the social psychology of Buddhism and other traditions of the sub-continent. The point of departure is the paradoxical role that fear seems to have in a range of Buddhist texts. On the one hand, fear is seen as a negative thing that should be left behind by the renouncer. Fear is a fact of life in the world. Freedom from fear is a corollary, or the equivalent of Nirvanna. On the other hand, fear is a positive thing that should be cultivated by the aspiring renouncer. Fear is a basic motivating factor, and is a prerequisite for exertion on the path to religious 
realization. The Buddha comes into the world both to create fear in living beings and to bestow freedom from fear. It seems, then, that fear assumes a pragmatic role, and in order to put this aspect of fear in a historical context I believe that we must look at the missionary stance of Buddhism and view the induction of fear through the preaching of hellfire and damnation as part of its arsenal of proselytizing.

Chapter 6 is based on the article 'The Religious Motivation of the Early Buddhists', Journal of the American Academy of Religion, 67 (4), 1999: 849-66. From motivational theory I will pick an approach that sees psychological incongruity, the discrepancy between an internal state and an external stimulus, as a basic motivating factor, and from this general approach I will pick two more specific conceptualizations of motivation, namely the theory of cognitive dissonance and a theory of secondary control. I should emphasize that I do not believe that the exercise of applying these theoretical constructs to early Buddhist textual material will render radically new answers to the question of why Buddhism arose. My aim is, first of all, to open a discussion about the use of modern psychology in the study of ancient and alien religious traditions.

This book is intended for an academic readership, first and foremost in Buddhist studies and indology in general. However, the present volume would, by its psychological approach, also serve as a suggestion for how some fundamental questions of religious studies might be approached. Therefore, it is my hope that it could be useful to people whose main research interest is in other religious traditions. 


\section{1 \\ THE HISTORICAL VALUE \\ OF THE KHANDHAKA OF \\ THE VINAYA PIT AKA}

In the first twenty-four chapters of the Khandhaka section of the Pāli Vinaya Pițaka we find the account of the enlightenment of the Buddha and the foundation of the Buddhist Samgha. This account is undoubtedly old. However, in his book on the original Skandhaka - of which the Pāli Khandhaka is one version - Erich Frauwallner expressed his belief that the timespan between the death of the Buddha and the composition of the text was at least 150 years. ${ }^{1}$ If Frauwallner was correct, the author of the Skandhaka would have described events of the distant past. I want to show that the time separating the origins of the Skandhaka from the events that it describes may be considerably shorter than previously assumed. Thus, the historical value of the work is greater than Frauwallner, and historians who have relied on his work, believed. It seems to me that the Skandhaka deserves more attention from scholars who work with early Buddhism.

When I use the term Skandhaka or 'original Skandhaka' without further specification I refer to a literary work that was composed more than two thousand years ago, that is the original form of the text. The term Skandhaka, then, is not used for the Skandhaka of any particular Buddhist school. The Skandhaka was composed at a time when there were no Buddhist schools. We know this because the Mahāsāmghikas include this text in their canon. It must have been composed before the first schism at the Council of Pạtaliputra, at which the greater part of the Samgha broke away from the Sthaviras, the elders. The Vinayas of six Buddhist schools are preserved. They are the Vinayas of the Sarvāstivādins, the Dharmaguptakas, the Mahīśāsakas, the Pāli school, the Mūlasarvāstivādins and the Mahāsāmghikas. ${ }^{2}$ The Skandhakas of the different schools are very similar in content. The greatest degree of congruence is 
found between the Skandhakas of the Sarvāstivādins, the Dharmaguptakas, the Pāli school and the Mahīsāsakas.. There is no reason to doubt that these Skandhakas have a common ancestor. Frauwallner believed that the Vinayas of these four schools are so similar because they are the products of one missionary enterprise, and that their Vinayas, therefore, can be traced back to the same text that was current at the starting point of the missions, i.e. Vidisāa ${ }^{4}$ What the Vinayas of these schools have in common, then, can be taken as the original content of this Vinaya of Vidisā.

According to the Dippavamsa and the Mahāvamsa, after the third council Tissa Moggaliputta sent missionaries to several places. In rock edict XIII, Aśoka says that he has sent his envoys to different peoples. ${ }^{5}$ Are the missionary enterprises, which are mentioned in the Sinhalese tradition, the same as the ones of Asoka's rock edict XIII? Frauwallner identifies the peoples mentioned in Aśsoka's edict with the countries in the Sinhalese tradition, and concludes that Aśoka must have sent the missionaries and that this enterprise was the origin of the four schools whose Skandhakas are most similar. ${ }^{6}$ However, Frauwallner's theory has been criticized. First, one could doubt Frauwallner's arguments for Vidis̄a as the origin of the missions. These arguments are:

1 Mahinda's mother was from Vidis̄ā, and Mahinda set out from Vidiśā on his mission to Ceylon.

2 Vidis̄ā was an important religious centre at the time of Aśsoka.

3 Relics of three of the missionaries have been found in stüpas near Vidiśā.

Second, the idea that a single missionary enterprise converted all these countries and peoples to Buddhism seems to be an oversimplification. $^{7}$

Having identified a Vinaya of Vidis̄ā, Frauwallner's next step is to clarify the relationship between this and the Vinaya of the Mūlasarvāstivādins. The latter differs from the other Vinayas in that it contains a large number of fables. Frauwallner points to a passage in the Mahāprajñāpāramitopadésa that mentions two Vinayas. One is the Vinaya of Mathurā, which includes also the Avadāna and Jātaka. The second is the Vinaya of Kasmīr, which has rejected the Avadāna and Jätaka and contains only the essentials. ${ }^{8}$ On the basis of the passage in the Mahaprajñ $\bar{a}$ pāramitopadeś $a$, he identifies the Vinaya of the Mūlasarvāstivādins 
with the Vinaya of Mathurā and the Vinaya of the Sarvāstivādins with the Vinaya of Kásmīr. ${ }^{9}$ Having linked the Mūlasarvāstivādins with Mathurā, Frauwallner goes on to argue for the independence of this school and its Vinaya from the schools that were the results of the missions, among them the Sarvāstivādins. He also argues that the Mūlasarvāstivādins was a very early school and that the Vinaya of Mathurā existed side by side and independently with the Vinaya of Vidisāa:

On the other side, the Mathurā community had nothing to do with these missions. It is an old community, much earlier than Aśoka, and plays an important role already at the time of the council of Vaísālī., ${ }^{10}$

But the Mūlasarvāstivādins belong to the same dogmatic tradition as the Sarvāstivādins. Frauwallner has foreseen this objection and argues that the foundation of communities based on Vinay $a$ and the rise of dogmatic schools are two completely different things. ${ }^{11}$ Therefore, the Mūlasarvāstivādins could well be a part of a larger school and, at the same time, be independent in terms of Vinaya. Lamotte does not agree that the Vinaya of the Mūlasarvāstivādins is the Vinaya of Mathurā mentioned by Kumārajī va:

Quant au Vin. des Mūlasarv. qui consacre deux Skandhaka à la biographie complète et suivie du Buddha, il ne provient pas d'une ancienne communauté bouddhique fixée à Mathurā dès le premier siècle du bouddhisme - comme le voudrait $\mathrm{M}$. Frauwallner (p. 37) - mais d'une immense somme de discipline close très tardivement et très probablement rédigée au Kásmir pour compléter le Vinaya des Sarvāstivādin. Lorsque, dans le passage étudié plus haut, Kumārajī va parle du 'Vinaya du pays de Mathurā en 80 sections' il a en vue, non pas le Vin. des Mūlasarv., mais l'antique Vinaya d'Upāli détenu en dernier lieu à Mathurā par le patriarche Upagupta. ${ }^{12}$

Lamotte says that the Vinaya of the Mūlasarvāstivādins (Msv. Vinaya) was closed much later. He offers three arguments. First, the Msv. Vinaya contains a prediction about Kaniska. The way in which the text treats the great king proves that it is considerably later than Kaniska who, Lamotte suggests, reigned some time during the second century AD. Second, the person of Saakyamuni in the 
Msv. Vinaya is not the sage of Kapilavastu but, rather, a superior god. Finally, Fa-hien, who visited India in 402 and 411 AD in search for copies of the Vinaya, does not seem to have had any knowledge of the Msv. Vinaya. ${ }^{13}$ 'Pour toutes ces raisons, on ne peut attribuer à cet ouvrage une date antérieure aux IVe-Ve siècles de notre ère. ${ }^{14}$ Raniero Gnoli adopts a position midway between Frauwallner's view of an early date and Lamotte's opinion of the fourth-fifth century $\mathrm{AD}$ as a terminus a quo for the Vinaya of the Mūlasarvāstivādins. ${ }^{15}$ On the basis of the the text's prediction concerning Kanișka and its tales of Kasmīr, Gnoli believes that the date of the text must be taken back to the time of Kaniska. ${ }^{16}$ In his analysis of the Vinaya of the Mūlasarvāstivādins, Panglung does not introduce an independent view with regard to the dating of the text, but, like Gnoli, ${ }^{17}$ he quotes Waldschmidt to show that this Vinaya is a very heterogeneous work. ${ }^{18}$ The period of compilation was long and the texts that constitute the extant Vinaya were 'laid down in different epochs, and subsequently patched up together'. ${ }^{19}$

The next step for Frauwallner is to push the origin of the Skandhaka another step back by comparing the Skandhaka of the Sarvāstivādins, Dharmaguptakas, Mahīsāsakas, the Pāli school and the Mūlasarvāstivādins with the Skandhaka of the Mahāsāṃnghikas. First, he observes that the account of the two First Councils is found in all these works. This shows that these accounts were part of the original Skandhaka. Frauwallner also suggests that the story of the Buddha's Parinirvāna was a part of the original work. What about the story of the illumination and the founding of the Order? In the cases the of Pāli school, the Dharmaguptaka and the Mahīsāsakas we find this tale in the beginning of the Skandhaka, and in the case of the Mūlasarvāstivādins there is a corresponding section in the Samghabhedavastu. But Frauwallner is faced with the problem that the story of the illumination and the early history of the Samgha seems to be lacking in the Skandhakas of the Sarvāstivādins and the Mahāsāmghikas. In Lamotte's words:

Dans les deux Vinaya que les traditions indigènes examinées plus haut présentent comme les plus proches de'l antique Vinaya d'Upāli - à savoir les Vin. des Sarvāstivādin et des Mahāsāmghika - il n'y a pas de traces de la biographie initiale du Buddha. ${ }^{20}$

The solution to this is quite simple. The Sarvāstivādins did have 
an account of these things, but by later tradition it was not regarded as a part of the Vinaya. In the case of the Sarvāstivādins, the Catusparisatsutra, the story of the origin of the four assemblies i.e. the monks, the nuns and the male and female lay supporters belongs to the Dìrghāgama of the Sütra Pitaka. Frauwallner believes that it originally belonged to the Skandhaka. The correspondence between the Catusparișatsūtra and the Mahāvagga 1-24 of the Khandhaka of the Pāli school is nearly complete. It also seems that the Mahāsāmghikas had the Buddha biography and the story of the early Samgha. Frauwallner points to a passage of a biography in Chinese, which says that the Mahāsāmghikas had a biography of the Buddha called Ta shih, i.e. Mahāvastu. ${ }^{21}$ Frauwallner believes that it originally belonged to the Skandhaka. The important point is that the Mahāsāmghikas actually had this text as did the other schools, because this supposition moves the composition of the biography of the Buddha and the history of the first Samgha further back to the time before the schismatic council of Pāṭaliputra.

\section{The historical value of the Skandhaka}

Waldschmidt has done a comparative analysis of the most important part of the Skandhaka, the Catusparișatütra. ${ }^{22}$ About the comparison of this account in the extant versions belonging to different Buddhist schools, Waldschmidt said:

Damit kann die wissenschaftliche Betrachtung der Begründung der buddhistischen Gemeinde auf ein Fundament tieferer Schicht als bisher erreichbar gestellt werden...$^{23}$

André Bareau, who, besides Frauwallner, has done the most thorough analysis of the material of the Buddha biography and the account of the early Samgha as it is contained in the Skandhaka and in passages of the Dìghanikāya, has a more pessimistic view of the value of this material:

L'anciennité et la diversité de nos sources met en relief cette hétérogénéité et cet émiettement des éléments qui ont servi à composer la biographie du Buddha, et ce double caractère conduit à douter fortement de l'historicité des données qui nous sont ainsi fournies. ${ }^{24}$ 
Oldenberg said about the stories connected with the Pạtimokkha rules:

That the histories, which have in this manner been added to the several rules of the Pätimokkha, have for the most part been invented, and, moreover invented in an extremely awkward and conventional way, will be perfectly evident to every one who reads a series of them one after the other. ${ }^{25}$

It should be noted, however, that the Pattimokkha rules themselves were laid down very early and furnish us, according to Pachow, with invaluable data for framing a picture of the economic and social conditions of their times. ${ }^{26}$ The accounts of the Mahāvagga and Cullavagga are given the same status, that of mere inventions, as those of the Vibhariga by Oldenberg, but he expresses ambivalence when it comes to the historical value of these texts:

The histories, as a whole, are undoubtedly pure inventions as those in the Vibhariga; this does not, of course, prevent their belonging to the most valuable sources for our knowledge of the life of the ancient Buddhist community. ${ }^{27}$

But if the stories of the Skandhaka are generally inventions like those of the Vibhainga, why is the historical value of the Skandhaka greater than that of the Vibhanga? According to Oldenberg, the essential difference between the Mahāvagga and Cullavagga and the Vibhainga is that the stories of the Vibhanga were added to an original basis of ecclesiastical regulations that had existed for some time, whereas most of the stories of the Mahāvagga and the Cullavagga were fixed in their context at the same time as the precepts that they explain. ${ }^{28}$

Oldenberg was of the opinion that the material of the Skandhaka gives a more authentic picture of a point of time in the history of the Samgha than the Vibhanga. However, according to Oldenberg the time separating the composition of the Skandhaka from the life of the earliest Samgha is considerable. Thus, it is hard to see how this material can be of truly great value from Oldenberg's point of view. Dieter Schlingloff expressed much the same view as Oldenberg about the stories of the Prātimokșasūtra:

In einer oder der anderen Geschichte mögen sich Erinnerungen 
an tatsächliche Vorkommnisse in der Gemeinde niedergeschlagen haben, meist sind die Erzählungen jedoch reine Zweckerfindungen, um die Verordnungen zu motivieren. ${ }^{29}$

Schlingloff takes the awkward relationship between rules and stories in the Prātimoksasūtra and the Vibhariga as proof of the considerable distance in time and spirit (zeitigen und geistigen abstand) between the disciplinary codes and the accounts connected with them. However, in the case of the Skandhaka it seems that one finds both uninspired - even misunderstood - stories and valuable legends with historical value. As suggested by Oldenberg's statements, the case of the Skandhaka is different from those of the Prātimokșasūtra and the Vibhariga. Substantial parts of the accounts give the reader a feeling of authenticity. In contrast to the Vibhaiga, many stories contained in the Pāli Khandhaka and the Catusparișatsūtra neither appear awkward nor do they seem like pure Zweckerfindungen. Horner said that 'the beginning of the Mahāvagga gives not only an impression but an account of an Order expanding and taking shape. ${ }^{30}$ Frauwallner emphazised the historical value of the Skandhaka both for the history of the Vinaya and for the history of Buddhism in general. ${ }^{31}$ The text is also an inexhaustible mine for the history of Indian culture and is of value for Indian linguistic history, he said. But Frauwallner's enthusiasm for the Skandhaka as a source of history is hard to understand in the light of his opinions on the composition of the text. With one example taken from the Mahäparinirvānasūtra he claims that he has proved all biographical accounts of the Buddha contained in the Skandhaka to be pure fiction. ${ }^{32} \mathrm{He}$ concludes:

The biography of the Buddha, which forms the framework of the old Skandhaka text, is not authentic old tradition, but a legendary tale, the work of the author of the Skandhaka. This gives rise to important inferences. As seen above, this biography is the basis of the most famous later biographies of the Buddha, and authoritative texts such as the Mahaparinirvānasūtra and the Catuṣparișatsütra are drawn from it. But these are the most important sources, upon which we have hitherto based our knowledge of the life of the Buddha. Once we have recognized that they all go back to a legendary tale, which was created only in the 4th century BC about one hundred years after the Nirvāna, they cease to represent primary 
sources. They may in future be utilized only in as far as we can recognize in them borrowings from earlier traditions. ${ }^{33}$

If we were to accept this view, the use of the Skandhaka as a source of history would be problematic. Indeed, if the accounts of the life of the Buddha and the early Samgha has no foundation in reality, there would be no reason to believe that the Buddha was a historical figure. If the stories of the Buddha completely lack reference to actual events, Frauwallner might as well regard these accounts as purely mythical constructions. But there are two arguments against Frauwallner's dismissal of the biographical accounts. First, the view that the original Skandhaka was the work of one author, who created a tale about the Buddha in order to embellish the rules of the Samgha, is doubtful. Second, the Skandhaka was probably composed considerably closer to the time when the Buddha was alive than Frauwallner believed. Therefore, there is no reason to assume that the author(s) lacked knowledge of the life of the Buddha and the early Samgha and that they, as a consequence, had to create a fictional biography.

\section{The date and composition of the original Skandhaka}

According to Frauwallner, the composition of the Skandhaka took place between 100 and 160 years after the Nirvāna (AN). In the light of more recent research on the dates of the Buddha's lifetime, it is difficult to agree with him. Its writing may have taken place so close to the life of the first Samgha that the author could have had his information about the subject of his text from the direct disciples of the Buddha. In fact, it cannot be totally ruled out that authors of the Skandhaka met the Buddha themselves.

Let us sum up Frauwallner's line of argument in his attempt to date the composition of the oldest Skandhaka work. ${ }^{34}$ First, he says, the Skandhaka must have come into being after the Council of Vais̄âli because all the traditions have the account of this assembly as part of the text. Second, it must have been composed before Aśoka because the Vinayas of the different schools that were results of Aśoka's missions clearly go back to a common source. Third, the text must have been made before the first schism because the Mahāsāmghikas have drawn from the work. Frauwallner concludes: 'And thus, if we stick to the most usual traditional dates, its rise 
belongs to the period between 100 and 160 after the Nirvāna. ${ }^{35}$ Obviously, the natural and relevant reference points in the dating of the Skandhaka are dates in the lifetime of the Buddha. When was the Parinirvanna? According to the Dipavamsa and the Mahāvamsa, 218 years elapsed between the death of the Buddha and the accession of Aśoka. ${ }^{36}$ Taking the date of Aśoka provided by this tradition we arrive at 544/543 BC as the date of the Buddha's Parinirvāna. When it was realized that there was a discrepancy between the Greek sources and the Ceylonese sources, the date of the Buddha's death was corrected to 486-77 BC, and this corrected long chronology was accepted by most modern scholars for a long time ${ }^{37}$ A different tradition encountered in earlier Buddhist Sanskrit works, and their Tibetan and Chinese translations, gives only a hundred years as the time separating the Buddha's death from the consecration of Aśoka. In 1983, Bechert showed that the corrected Ceylonese chronology could not be maintained. ${ }^{38}$ Neither can we, according to Bechert, accept the shorter chronology suggested by the Indian sources and its Chinese and Tibetan translations. Bechert chooses instead to calculate the date of the Nirvanna on the basis of the lists of patriarchs and arrives at a period between 85 and 105 years before Aśoka's consecration. He goes on to place the Council of Vaisāalī between 40 and 50 years after the Nirvāna. Moreover, in moving the date of the Buddha's Nirvanna to some time between 353 and $373 \mathrm{BC}$ (taking $268 \mathrm{BC}$ as the year of Aśoka's consecration), Bechert is not only advancing his own view of the matters, he says. A careful study of the works of Mendis, Lamotte and Eggermont will show the Ceylonese chronology to be untenable. ${ }^{39}$ Bechert slightly alters these dates in a later article, giving $80-130$ years before Aśoka's coronation as the period within which the Buddha's Nirvāna most probably took place. ${ }^{40}$ Here, he takes Alexander's Indian campaign as the definitive terminus ad quem.

The papers from the Fourth Symposium on Buddhist Studies, edited by Bechert, are more or less concurrent in the view that the date of the Buddha, or the Nirvāna, must be moved forward. However, complete unanimity is not achieved on the question of how much the date should be altered, or what methods should be used in the search for the correct year of the Nirvanna. If one tries to extract one acceptable date for the Buddha's death from the different methods and respective results in the papers of the symposium, it seems to me that $400 \mathrm{BC}$ is the best approximation. This is the date which has the highest degree of compatibility with the estimations 
of Gombrich, ${ }^{41}$ Bechert, ${ }^{42}$ Bareau, ${ }^{43}$ Simson, ${ }^{44}$ Härtel,${ }^{45}$ Schmithausen ${ }^{46}$ and Hirakawa. ${ }^{47}$ What is the significance of the later date of the Buddha on the historical value of the Skandhaka? The later date for the Nirvanna has an impact both on our knowledge of the history of north India and on the concept of an axial age in the context of world history, Kulke says. ${ }^{48} \mathrm{He}$ continues: 'Third, we have to reassess the historiographical value of early Buddhist literature in view of Buddha's probable date around $400 \mathrm{BC}^{\prime 49}$ and 'It is self-evident that such a late date of early Buddhist literature changes considerably its historiographical significance and relevance. ${ }^{50}$ For my concern, the most important implication of the later dating of the Buddha is that we must place the origination of the original Skandhaka closer to the events it describes. The reason is simple: this work cannot have been composed 100 to 160 years after the Nirvāna and, at the same time, well before Aśoka. It is equally impossible to maintain the period of 100 to 160 years between the Nirvāna and the composition of the Skandhaka and, at the same time, hold on to the view that the text was composed before the schism at Pâtaliputra. However, it is reasonable to maintain Aśoka's time as the terminus ad quem for the Skandhaka.

Frauwallner chose the period between 100 and 160 AN as the time for the composition of the Skandhaka. He adopted 100 AN as the earliest possible date for the Council of Vaisāalī as mentioned in the Ceylonese chronicles and the Skandhaka itself, and he took $160 \mathrm{AN}$ as the latest possible date for the schism which split the Buddhist community into Sthaviras and Mahāsāmphikas, traditionally the Council of Pâtaliputra. To throw some light on the dating of the Council of Pătaliputra, which is Frauwallner's terminus ad quem for the composition of the Skandhaka, one can consult Bareau. ${ }^{51}$ In considering the different traditions concerning this council, Bareau presents us with four possible dates: $100 \mathrm{AN}, 116$ $\mathrm{AN}, 137 \mathrm{AN}$ and $160 \mathrm{AN}^{52} \mathrm{He}$ immediately rejects the two extremes. In the same way as in his paper in the Fourth Symposium, Bareau makes his choice among the diverging dates offered by the different textual traditions, after reflecting on the probability of the timespan separating the Council of Pâtaliputra from the Council of Vais̄ālī:

Si nous considerons la duree de l'intervalle qu'implique chacune de ces deux dates precises, 116 ou 137 EN, entre le concile de Vaiśālī et celui de Pataliputra dans la tradition qui 
nous l'a transmise, c'est-a-dire six ans ou trente-sept ans, c'est bien la seconde qui parait de beaucoup la plus vraisemblable. ${ }^{53}$

If Bareau is right, Frauwallner could have narrowed his timespan to the period between $100 \mathrm{AN}$ and $137 \mathrm{AN}$, which is Bareau's most likely date for the Council of Pătaliputra. Although Bareau is sceptical about the exactness of his sources, he does not seem to question these two dates on which his calculations are based. He concludes:

Pourtant, rien ne nous assure par ailleurs de l'exactitude de cette derniere date et nous devons donc nous contenter de penser que le schisme eut lieu dans la premiere moitie, plus precisement dans le second quart du IIe siecle apres le Nirvānạa. ${ }^{54}$

More important is the date of the Council of Vaisâalī as this was the terminus a quo for Frauwallner. There is not complete agreement regarding the date of the council in the different textual traditions. The Vinayas of the Theravādins, the Mahīsāsaka, the Dharmaguptaka and the Haimavata put it at 100 years after the Nirvāna. The Vinaya of the Sarvāstivadin and the Mūlasarvāstivādins have 110 years. Other sources have one of these two dates. Should we trust these dates, as Frauwallner does? A passage in the Cullavagga can be taken as an indication that the time separating the Buddha from the participants at the Council of Vaiśālī was not several generations, as stated by both traditions. It says that there was a thera called Sabbakāmin who had received ordination 120 years earlier and who was sharing a cell with Ānanda. According to Dīpavamsa IV.48-52, Sālha, Revata, Khujjasobhita, Yasa and Sambhūta had also shared cells with the thera Ānanda. Obviously, we cannot accept the statement that Sabbakāmin and the other elders at the council had received ordination 120 years before, which would mean that they were at least 140 years old at the time of the council - 20 being the minimum age for ordination as laid down in Mahāvagga I.49 and parallel texts. But must we necessarily reject the statement that Sabbakāmin had once shared a cell with the venerable Ānanda? There is a different solution: what if Sabbakāmin had actually been ordained at the time of the Buddha and had shared a cell with Ānanda and what if the Council of Vaiśāli took place, 
say, 40 years after the Buddha's Nirvāna? When the time from the Nirvāna to the Council of Vaiśālì , by the later tradition, was settled as one century, the redactors of the Vinaya had to manipulate Sabbakāmin's age at the time of the council in order to get things right. Horner suggests that, in the translation of the Cullavagga, Sabbakāmin is identical with Sabbakāma of the Theragāthā CCXXIII. Here, it is said that that he was born in Vaisāali after the Buddha had passed away and that he had received instruction from the Treasurer of the Norm, i.e. Ananda. In his evaluation of the sources on the date of the Buddha, Akira Hirakawa comments, in passing, on the age of the disciples of Ānanda who were present at the Council of Vaísālì :

If his oldest disciples lived to be over a hundred years old, it is not impossible that some would still be alive a century after the Buddha's death. It seems that it was not unusual for a bhiksu who lived a regulated existence away from secular life to survive more than a hundred years. ${ }^{55}$

This sounds too incredible. Moreover, according to Dipavamsa IV.48-52, the elders of the council - Sabbakāmin, Sālha, Revata, Khujjasobhita, Yasa, Sambhūta of Sāna, Sumana and Vāsabhagāmi - had previously seen the Tathägata. Again, we must reject the possibility that all these theras actually were 140 years old, and again, we are confronted with two solutions to the problem:

1 The elders did not know the Buddha. This tradition could have been invented, perhaps, to increase the authority of the participants of the council.

2 The Council of Vaisāāi took place at a time when direct disciples of the Buddha were still alive, say 40 years after the Nirvāna. Later, when it was decided that the council had taken place 100 years, or more, after the death of the master, the redactors had to manipulate the age of the elders to make the numbers add up. ${ }^{56}$

Bechert puts the question of the date of the Council of Vaisāli into the context of the later date of the Buddha. He says:

The Council of Vaisāāi may be dated about 40 to 50 p.N. [post Nirvānạa]. The tradition that Sānavāsī, one of the great 
authorities of this convocation, was a personal pupil of Ānanda, becomes now credible..$^{57}$

However, there is not complete agreement among scholars about how to treat the councils. Franke, for instance, having rejected the historicity of the First Council ${ }^{58}$ says:

We may confront the chronicle of the Second Council with even greater indifference. This is not only a merely literary construction; it does not even possess any relevant subject matter. ${ }^{59}$

Franke is more or less alone in his clear rejection of the credibility of the account of both of the First Councils. Hofinger says: ' $\ldots$ on peut tenir pour assurée l'historicité du concile de Vais̄ālī' ${ }^{60}$ Lamotte, in his conclusion on the subject of the two First Councils, asks for caution: 'Le peu qu'on en a dit suffit à montrer qu'il serait imprudent de se prononcer pour ou contre l'historicité des conciles. ${ }^{61}$ What does Bareau have to say about the date of the Council of Vais ālì? First, he concludes a discussion of the traditions by expressing distrust:

Le fait est là: la date du concile de Vaiśālī a été fixée, et chez les Sthavira seulement, vers 200 EN, c'est-à-dire un siècle environ après la date ainsi choisie. Par conséquent, elle est suspecte a priori. ${ }^{62}$

All we can say, according to Bareau, is that the council took place between the Buddha's Nirvāna and the first schism. Nevertheless, he ends his chapter by making a reserved conjecture:

Nous sommes donc amenés, sur la foi de ces indices, à placer le concile de Vaiśālī vers la fin du I ${ }^{\text {er }}$ siècle EN, par conséquent à une date assez proche de l'an 100 EN qui est donné par les traditions des Sthavira. ${ }^{63}$

In the latest publication on the date of the historical Buddha, Bechert has not changed his opinion on the issue. He says that the scepticism vis-à-vis all attempts to determine the date of the Nirvanna does not preclude him from subscribing to the view that we must, in Lamotte's words, 'drastically bring forward the date of the Buddha's Nirvāna’ ${ }^{64}$ 
To sum up, Frauwallner's dating of the Skandhaka cannot be accepted as neither the traditional dating of the Nirvāna nor the period of 100 or 110 years between the Nirvāna and the Council of Vaiśālì can be retained. Generally speaking, in accepting a later date for the Buddha's death we cannot, at the same time, uncritically move all events whose dates have been fixed in relation to the Nirvāna for the simple reason that they will clash with dates whose authenticity is more certain. On the contrary, when we move the Nirvāna closer to Aśoka we also move the life of the Buddha and the foundation of the Samgha closer to the composition of the Skandhaka. How close? If Bechert is correct in placing the Council of Vaiśāli between 40 and 50 AN, the time separating the Nirvāna and the composition of the Skandhaka may be no more than 40 years. This probably means that direct disciples of the Buddha lived at the time when the original Skandhaka was composed and we cannot completely rule out the possibility that the authors of the Skandhaka met the Buddha themselves.

So far we have presupposed that the Skandhaka originated after the Council of Vaísālì. As long as the date of the council has been thought of as settled, the author of the Skandhaka has been separated from his subject matter by more than a century. We have already seen that Frauwallner's opinions about the date of the Council of Vais̄âli cannot be supported. Can we agree with him when he says that the Skandhaka was composed after the Council of Vaisanāin? I see two reasons for not accepting Frauwallner's view without hesitation. The first, and weaker, objection that can be made against it is to refuse to believe, like Franke, in the historicity of the Council of Vaissāli and to suggest that the fictional tradition about this council originated very early. The fact that the story of the council is found in the Skandhaka would consequently not entail any definite limit of time for the composition of the work. A second, and stronger, argument can be made by pointing to the uncertainty surrounding the conjectures that are the foundation of Frauwallner's view. A necessary condition for concluding, like Frauwallner, that the Skandhaka was composed after the Council of Vaisāali is that the work was composed by one person within a limited period of time. If one admits the possibility that the Skandhaka was fashioned by different authors over a longer period of time, one must acknowledge the chance that the sections of the Skandhaka dealing with the councils were added after the other parts of the work had been finished. Conversely, if one takes the narration of the councils 
as proof that the whole of the Skandhaka was composed after the councils, one must accept the condition that the work was composed at a certain point in time, most likely by one author. Oldenberg's views are not harmonious with those of Frauwallner. Oldenberg says:

The account of the Councils follows upon the actual closing chapter of the Vinaya, containing the laws for the Bhikkhunīs. It is evident that this account is written as the conclusion or an appendix to the Vinaya, and that, accordingly, the main substance of the Vinaya laws were not composed later. It remains to be considered whether, at the time the closing chapter was composed, the principal part of the work did already exist as a complete whole, or whether the closing chapter and the other portions of the Vinaya were composed at one and the same time. It seems to me that the first of these alternatives possesses by far the greater amount of probability, not to say certainty. ${ }^{65}$

Oldenberg goes on to give the reasons for his opinion that the main body of the Skandhaka was composed before the sections dealing with the councils. First, the redaction of the whole Vinaya is said, in the closing chapter, to have been made immediately after the death of the Buddha. Second, the subjects of discussion at the Second Council are not mentioned in other parts of the Vinaya. ${ }^{66}$ After further argumentation Oldenberg concludes:

The discussion of the ten propositions is given in the form of an account of the Council of Vesali, as an appendix at the end of the Vinaya; this, I think, is the best proof of the fact that when the dispute concerning the ten propositions was being carried on, the Vinaya itself already existed, that IT IS OLDER THAN THE COUNCIL OF VESALI. ${ }^{67}$

Of course, it is Frauwallner's and Oldenberg's fundamentally different views concerning the nature of the birth of the Skandhaka, and the whole of the Vinaya, that are the source of this radical disagreement. Where do Oldenberg's opinions leave us regarding the question of the dating of the original Skandhaka and the question of the degree to which the earliest Samgha can be studied through the text? Of the Skandhaka, Oldenberg says that its style of 
composition corresponds so exactly with that of the later written parts of the Vibhariga '.. that it may be assumed with certainty that these texts were composed almost contemporaneously' ${ }^{68}$ The Skandhaka, then, would not belong to the earliest parts of Buddhist literature, as they would presuppose the existence of the Prâtimokșa rules. ${ }^{69}$ However, Oldenberg bases his calculations on the chronological system of the Mahâvamsa and Dipavamsa when suggesting a date for the composition of the Skandhaka. He arrives at 383 BC as the approximate date of the Council of Vaisāāi and 400 $\mathrm{BC}$ for the revision of the Vinaya, including the Skandhaka. ${ }^{70}$ Frauwallner's hypothesis concerning the relationship between the Skandhaka and the account of the council is opposed by Étienne Lamotte, who says:

Et si le récit des conciles se rattacha momentanément à la tradition du Vinaya, il demeure évident, comme le constatait déjà M. Demiéville, que ses rédacteurs n'étaient pas les mêmes que ceux des Vinaya auxquels ce récit est adjoint. ${ }^{71}$

Summing up the above discussion, it is clear that Frauwallner's conjectures concerning the dating of the original Skandhaka are to a large degree invalidated. If one accepts the Council of Vaśāli as the terminus a quo for the composition of the work, its author may have lived 40 years after the Nirvāna. Thus, it is not impossible that the writer lived during the Buddha's lifetime. This goes well with the statements in the canonical sources that the participants of this council knew the Buddha and Ānanda. On the other hand, if one does not accept the Council of Vaísāli as the terminus a quo, the time separating the author of the Skandhaka and the Buddha and the earliest Samgha is undetermined. We may conclude that not knowing the time separating the author of the Skandhaka from the life of the Buddha and his first followers is not a factor that diminishes the value of the text as a source in the study of the earliest Samgha. The trustworthiness of the textual transmission of later centuries is, of course, a wholly different question. 


\section{RELIGIOUS MOTIVATION AND THE RELATIONSHIP BETWEEN THE EARLY SAMGHA AND THE LAITY}

The aim of this chapter is to show how the relationship between the Samgha and the laity originated and were maintained in early Buddhism. I believe that in order to understand the religious motivation that made people join the early Samgha we need to look at the social processes that formed the relationship between Samgha and laity. My main source is the Vinaya Pițaka of the Pāli canon. In the previous chapter I argued that the historical value of the Khandhaka section of the Vinaya Pitaka may be far greater than previously assumed, and this text is a rich source of information about the growth of the early community of monks and its relationship to the outside world.

In order to illuminate the relationship between the Samgha and the laity I will employ two concepts from Bryan Wilson's sociology of religion: conversionism and introversionism. In his book Religious Sects Wilson gives a definition and a general typology of sects. ${ }^{1}$ Although his own application of the typology is limited to groups within the Christian tradition, his categories are of such a general kind that they can be applied elsewhere. Wilson draws attention to the need for a typology the relevance of which is not limited to groups within the Christian tradition:

If the sociology of religion is to move forward, we must create categories which allow us to study comparatively the social functions and development of religious movements. As a consequence, such studies must shun categories dictated too specifically by the characteristics of a particular theological tradition. Obviously, the types we can use are still drawn mainly from the material at our disposal, especially from Christian 
movements. But it is imperative that we should try to enlarge their application, and, if needs be, modify their formulation in the light of this extension of their meaning, so that we shall have a series of analytical instruments which will no longer be centred on a particular civilization and religion (in this case, Christian). ${ }^{2}$

I take this as an invitation to apply Wilson's types in the study of religious traditions other than the Christian. In my opinion, Wilson's typology gives us a useful framework for the study of the early Samgha and the social processes that took place in the early stages of Buddhism. Wilson defines a sect in terms of eight qualities which are present in the religious community and it is clear that the early Buddhist Samgha conforms to his definition.

Wilson also distinguishes seven cardinal types of sects based on the nature of the sects' response to the world. They are the conversionist, the revolutionary, the introversionist, the manipulationist, the thaumaturgical, the reformist and the utopian. These are not static categories. One sectarian movement can have elements of different orientations and a sect can, and in most cases will, move from one category to another over time. Thus, the typology is suited to measure change in a sect's orientation towards the world.

The psychologist Gordon Allport used the concept of extrinsic $v s$. intrinsic motivation to describe religious behaviour. A person who has an extrinsic orientation uses religion to achieve other ends; the religion is not the ultimate goal in itself. The relationship to religion is instrumental and the beliefs can be shaped accordingly to fit his or her mundane desires. The heterodox systems served important functions in the pursuit of worldly or extrinsic goals for certain parts of Indian society. For instance, the new religious ethics seems to have suited an emerging urban merchant class. ${ }^{3}$ However, in the case of early Buddhism I believe that it was, first of all, members of the lower strata of society who had mundane motivations for joining the Samgha. I will look at the motivation of those who came for the security and status of monkhood and those who came 'purely for a comfortable living' as Pachow puts it. ${ }^{4}$ As I will show, this extrinsic motivation is abundantly documented in the Khandhakas of the Vinaya Pitaka.

I have introduced three concepts that I will apply in my approach to the textual material: introversionism, conversionism and extrinsic 
motivation. The aim of this chapter is to show that early Buddhism changed from a conversionist to an introversionist relationship to the world and that this process was a consequence of the extrinsic motivation of the potential members of the Samgha.

\section{Extrinsic motivation}

In Chapter I.39 of the Mahāvagga of the Vinaya Pitaka (MV I.39) people go forth because they are afflicted with the five diseases that were prevalent among the people of Magadha and they cannot get the attendance of the physician Jìvaka Komārabhacca outside the Samgha as he is too busy caring for the king and the monks. Typically, they ask themselves whether they should go forth among the sons of the Sakyans; then monks would look after them and the physician would attend to them. In MV I.40 some soldiers join the Samgha in order to escape military service. In MV I.41 a thief has gone forth to hide. In MV I.42 a thief breaks out of jail and joins the Order. It has been decreed by King Bimbisāra that nothing should be done against the sons of the Sakyans, and therefore the criminal feels safe among the recluses. In MV I.43 a man is on the run, having committed a crime. In the royal palace it is written that this man should be killed when seen. He joins the Samgha to hide. In MV I.44 and 45, men who have been scourged and branded as punishment join the Order of monks. In MV I.46 a debtor goes forth among the monks in order to escape his creditors. In MV I.47 a slave has run away and taken shelter in the Samgha. In MV I.48 a blacksmith joins the Order to hide from his parents. In MV I.49 a group of boys, with Upāli as their leader, go forth in order to live at ease. Getting up in the night they cry out for food. These are examples of extrinsically motivated monks.

If we look at the Theragāth $\bar{a}$ and Ther $\bar{\imath} g \bar{a} t h \bar{a}$, we find more passages about monks and nuns who were motivated by worldly goals. According to Dhammapāla's commentary, the poor and hardworking Sumangala of Theragāthà XLIII joins the Order because he sees that the recluses live in sheltered lodgings, dress in delicate robes and eat well. He is admitted to the Order by the thera simply out of compassion. In Ramaṇiyavihārin of Theragāthā XLV we have a typical example of the kind of monk who throughout the history of Buddhism made the Samgha the object of accusations of laxity: 
Reborn in this Buddha-age at Rājagaha, as the son of a leading citizen, he lived in youthful wantonness. One day he saw the king's officers arresting an adulterer, and growing agitated, he listened to the Master teaching, and left the world. As a bhikkhu, but still susceptible to fleshly lusts, he made himself a wellgarnished chamber, well furnished as to food and drink, seat and couch; and so he ever dwelt. For this reason he was known as Raman̄īyavihārin (Pleasant-lodge Brother). ${ }^{5}$

Nìta of Theragātha LXXXIV was the same kind of monk:

When grown up he thought: 'These Sākiyan recluses are very lucky in that they are well provided with all necessaries. It is a happy life, that of a member of the Order.' So he entered it to get pleasure from it, paid scant attention to his exercise, ate his fill, spent the day in idle talk, and slept all night long. ${ }^{6}$

Aḍ̣hakāsī of Therīgāthā XXII joins the Samgha to escape her life as a prostitute. The same is the case for Ambapā $\sqrt{1}$ of Theri $g \bar{a} t h \bar{a}$ LXVI. Discussing the case of a prostitute joining the Samgha, Mylius writes: 'Das war sicherlich kein Einzelfall, und es gibt allerlei Hinweise der zeitgenössischen Quellen, dass der Sangha nicht ausschliesslich aus edlen Motiven aufgesucht wurde. ${ }^{7}$

But it was not only Buddhists who were extrinsically motivated. Or, to put it differently, people who wanted to adopt a religious life in the pursuit of an easy living sometimes had other, and perhaps better, opportunities than the Buddhist Samgha. Warder argues that there existed a broad milieu of ascetics and wanderers before the great heterodox sects and that the organized schools originated as a consequence of changes in the society:

No doubt the $\bar{a} \mathrm{j} \overline{1} v a$ was embraced by many who wished to escape the need to work or the responsibilities of family life, not to speak of conscription, forced labour, or slavery, and was a carefree existence very different from the life of strenuous asceticism, complicated discipline, and intensive study required of members of most of the organized sects afterwards (although freedom from all worldly cares was always stressed). ${ }^{8}$ 
Thus, according to Warder, Buddhism originated in a religious environment in which extrinsic motivation was common.

The problem of extrinsic motivation for joining the Samgha had no ultimate solution. On the contrary, it seems to have grown as the number of monasteries rose and their wealth and prestige increased. According to Gunawardana the kings of medieval Ceylon were constantly engaged in purifying the Samgha by expelling monks unsuited to the vocation. ${ }^{9}$ Carrithers says that the Samgha of Ceylon came to be seen as consisting of two parties; one was the village Samgha with their involvement in lay life and the monasteries' control of vast areas of land for cultivation, the other was the forest-dwellers and ascetics. ${ }^{10}$

Melford Spiro discusses the motivation of the Burmese monks in similar terms. ${ }^{11}$ According to Spiro, the Burmese distinguish between three types of motivation to join the Samgha: first, religious motives; second, the desire to escape the miseries of worldly life; and, third, the wish for an easy life. Spiro's first category corresponds to Allport's intrinsic motivation, whereas both the second and third categories would be aspects of extrinsic motivation Most of Spiro's informants say that the greater part of Burmese monks join the Samgha in order to escape miseries or have an easy life. They are extrinsically motivated. Because of their easy living there are five times as many monks as there would be otherwise, the informants claim. ${ }^{12}$ Although the monks themselves give nobler motives for their decision to join the Samgha, Spiro is clearly of the opinion that the extrinsic motivational factors are very important in the recruitment of monks. According to Spiro, almost all monks are from poor village families. This is also the case in Thailand. ${ }^{13}$ The Samgha offers a higher standard of living and a higher status for poor villagers than they would achieve outside the Order. Joining the Order also offers the possibility of an education for poor youngsters.

It seems, then, that we have a situation in modern Theravāda countries that has antecedents in the earliest Samgha. The modern situation - in which poor people from the countryside are motivated by the increase in living standard and status - is not new. From the stories of the Khandhakas it seems that extrinsic motivation was already a problem at the time of the Buddha. In the rest of this chapter I will show how this tendency towards extrinsic motivation has, from the very start, been an essential force in the shaping of 
the relationship between the Samgha and the laity and, thus, in the shaping of the structure of Buddhist societies.

\section{The consequences of extrinsic motivation}

The Samgha always depended on the support of the laity. To receive support, the monks had to be, or at least appear as, pure and distinguished individuals. The Samgha had to stand out as a body worthy of support. The monks were expected to lead lives devoted to high religious ideals and they were expected to light up the world with their holiness. People who joined the order simply to benefit from its security and the spiritual and material support it enjoyed corrupted the Samgha. At a very early stage it became necessary to keep these people out. It was essential to show the world that the monks took no interest in worldly pleasures. This need brought about a change in the early Samgha's relationship to the world. By physical separation and segregation by outward appearance the Samgha withdrew from the world to cultivate and demonstrate its own holiness and aloofness. It was a change from an outwardly minded conversionism to withdrawal and segregation - to introversionism.

\section{From conversionism ...}

In Wilson's typology, conversionism is one of the seven basic responses to the world that a sect can adopt. ${ }^{14} \mathrm{I}$ use the term conversionism to denote the great emphasis that is put on the conversion of new members to the Samgha and the lack of restrictions on admittance. The early Buddhists seem to have engaged in fervent and competitive proselytizeing activity towards both other sects and Brahmins and other important members of society.

In the Khandhaka section of the Vinaya Pitaka we have the most detailed description of the early stages of the Buddhist Samgha available in Buddhist literature. Its account starts right after the enlightenment of Gotama. The young prince is now a Buddha but he has no congregation yet. Initially, he does not want to face the risk of experiencing the weariness and vexation caused by the dull intellects of his potential pupil and he must be persuaded by Brahmā Sahāmpati to teach the Dhamma. The first question that arises is to 
whom he should preach. He decides to approach the group of five ascetics with whom he previously has practised asceticism. These five form the first Samgha.

Part I.7 of the Mahâvagga is about the conversion and going forth of Yasa, the son of a rich merchant of Benares, and about the conversion and going forth as a lay disciple of Yasa's father. The Buddha uses his charisma to win over Yasa as a monk and his father as a lay disciple. When the great merchant sees his son, who has run away from home in order to join the Buddha's following, he begs him to come home for his mother's sake. When the merchant asks his son to come back, the Buddha tells him that Yasa cannot turn back to the low life and enjoy sensual pleasures as he did before when he led the life of a householder (gahapati). In MV I.8 the mother and former wife of Yasa take refuge in the Buddha, the Dhamma and the Samgha as lay disciples and become the first women lay disciples using the three-word formula. In MV I.9 four friends of Yasa approach the Lord and are ordained. In MV I.10 sons of other families in Benares approach the Lord and are ordained.

In MV I.11 the Buddha tells the monks to walk out and preach Dhamma. In MV I. 12 monks bring in from different regions people who wish to go forth and who want ordination, and the Buddha allows the monks to go forth and ordain where they are, without coming back to him. Of course, this must have been necessary for Buddhism to have a substantial geographical expansion. The Buddha makes the rules of how the ordination should be carried out by the monks. Through such rules, the proselytizeing activity of the monks becomes easier and more efficient.

In MV I.14 the Buddha meets thirty young men in a forest. One of these men has no wife and a prostitute is brought along for him. While the men are amusing themselves, the prostitute takes their belongings and runs off, and it is while the men are looking for the woman that they meet the Buddha. The Lord asks the men what would be best for them - to look for the woman or to look for the self. The men agree that it would be better that they should look for the self. The Buddha preaches and the men see Dhamma and are converted.

What do these stories about the conversionist activities of the Buddha and his early disciples tell us? It is clear that the early 
Buddhists tried to win followers but there were other sects with the same ambitions. In the Sāmaññaphalasutta, King Ajātaśatru is tormented by the fact that he has killed his own father, King Bimbisāra, and in his affliction he is unable to enjoy himself as kings are supposed to in their spare time. The ministers each recommend that he go to see one of six religious teachers: Pūrana Kassapa, Makkhali Gosāla, Ajita Kesakambal̄̄, Pakudha Kaccāyana, Sañjaya Belatthiputta and Nigaṇtha Nātaputta. However, King Ajātaśatru has already paid visits to the six heretics and his mind has not been appeased. But when a councillor suggests that he seek out the Buddha for guidance, the king finally sees some hope and prepares his elephants for a nocturnal excursion. He arrives at Jīvaka's mango grove, where the Buddha is staying. But before the Buddha will soothe the king's mind with his superior doctrine and his superior pedagogical skills, the king is asked to give an account of the six heretics' answers to his question.

According to Basham, the doctrines ascribed to Pūraṇa Kassapa, Makkhali Gosāla and Pakudha Kaccāyana are probably all aspects of early Ajj̄ vikism. ${ }^{15}$ Ajita Kesakambali represents materialism that must have been a forerunner of the Cārvākas; Niganțha Nātaputta may be identified with Mahāvīra; and the account of Sañjaya Belatthiputta may be a satirical description of agnostic teachers' unwillingness and inability to answer metaphysical questions. From the testimony of the Sämaññaphalasutta and other texts, it appears that there was a high degree of competition among the different sects and their leaders. ${ }^{16}$

In the Tevijjasutta of the Digha Nikāya, the Buddha is approached by two young Brahmins, who ask whether the teachings of the various Brahmin teachers, Addhariyā, Tittiriyā, Chandokā and Bavarikā, lead to the same right goal. The answer is that only the path of the Buddha leads to salvation. Another story of competition between the great sect leaders is found in Chapter $\mathrm{V}$ of the Cullavagga of the Vinaya Pitaka (CV V). Here, a great merchant in Rājagaha makes a wooden bowl out of a block of precious sandalwood. He puts it on a high pole and declares that whoever is a perfected one and has psychic power and gets the bowl down from the pole shall have it. Pūrana Kassapa, Makkhali Gosāla, Ajita Kesakambalin, Pakudha Kaccāyana, Sañjaya Belatṭhiputta and Nātaputta the Jain approach the merchant and claim the right to the bowl. However, it is a Buddhist, Pindola the Bhāradvāja, who actually wins the contest. He rises above the 
ground, takes the bowl, circles Rājagaha and lands by the house of the merchant. However, when the Buddha hears this he reproaches Piṇ̣ola the Bhāradvāja and he forbids the monks to exhibit psychic powers to householders.

The competitive element in the proselytizeing activity of early Buddhism is clearly expressed in MV I.15-20. In these passages, the Buddha demonstrates his superior magical powers to a community of matted hair ascetics (jațila). He performs many wonders, showing complete mastery over all beings and over time and space. When the matted hair ascetics want to worship their sacrificial fires, it is only with the psychic powers of the Buddha that they are able to chop sticks and kindle and extinguish the fires.

In MV I.15 the Buddha arrives in Uruvelā. He approaches the matted hair ascetic Kassapa of Uruvelā and asks him if he can spend a night in the fire-room. Kassapa does not object but warns the Buddha that there is a fierce king of naggas, a terribly poisonous snake, in the room. To the amazement of the matted hair ascetics the Buddha masters the snake with his superior power. In MV I.16 the Buddha stays in a jungle thicket near the hermitage of Kassapa of Uruvelā and in the night the four great kings, having illuminated the whole place, approach the Lord to hear Dhamma. Kassapa is amazed and admits to himself that the Buddha has great powers but he thinks himself to be of higher perfection.

Kassapa is stubborn in his belief that he is of greater perfection than the Buddha in spite of the wonders performed by the latter. A great sacrifice is to be held and the whole of Anga and Magadha attend and bring along food. Kassapa is worried that the Buddha will perform a wonder in front of the people, thus increasing his popularity and honour at the expense of Kassapa's. The Buddha, however, understanding in his mind the mental reflections of Kassapa, goes away and does not show himself. When Kassapa asks him why he did not come to the sacrifice the Buddha tells the ascetic that he knew his thoughts. Again Kassapa is amazed, but he still cannot admit that the Buddha is greater than himself.

In MV I.20 the competition between the Buddha and the matted hair ascetic reaches its climax. The Buddha performs many wonders. Sakka digs a tank for the Lord to wash his robe and the great god puts down a rock for him to knead it. A devatā in a tree bends down a branch for the Lord to hold on to when he climbs out of the water. Sakka puts down a new rock for him to stretch out his robe. Kassapa 
is impressed by these wonders but still believes himself to be superior to the Buddha. Now the Buddha exhibits complete mastery over space and time by moving at will to other worlds, where he picks fruits and flowers and offers them to Kassapa. The ascetic, however, refuses to admit that the Buddha is of greater perfection. Then the matted hair ascetics want to tend their fires. However, they are unable to chop sticks because of the power of the Buddha. On the Lord's command 500 sticks are chopped. The ascetics can neither kindle the fires nor extinguish them. At the Buddha's command the fires are kindled and extinguished. Moreover, the Buddha makes 500 fire vessels for the ascetics to warm themselves by after plunging in and out of the river. Then a flood comes and the Buddha makes the water pull back and he walks on dry ground. Kassapa is still not convinced of the Buddha's superiority.

In spite of the wonders performed, the leader of the matted hair ascetics believes himself to be of greater power and of greater religious perfection than the Buddha. Each time a wonder is performed, Kassapa must admit to himself that this recluse is of great power, 'but he is not a perfected one as myself' ${ }^{17}$ The Buddha grows tired of Kassapa's stubbornness:

Then it occurred to the Lord: 'Now for a long time it will occur to this foolish man, "Truly the great recluse is of great psychic power, of great might; but yet he is not a perfected one as I am.". Now suppose I should deeply stir this matted hair ascetic?' ('yam nūnāhaṃ imam jaṭilaṃ saṃvejeyyan ti.') The Lord spoke thus to the matted hair ascetic Kassapa of Uruvelā: 'Neither are you, Kassapa, a perfected one nor have you entered on the way to perfection, and that course is not for you by which you either could be a perfected one or could have entered on the way to perfection. ${ }^{18}$

In other words, the Buddha wants to bring about samvega, emotional disturbance that leads to religious motivation, in the ascetic to convert him to Buddhism. The only reason that the Buddha stays with the matted hair ascetics is to win them over to his own sect, and this is his only motivation for humiliating Kassapa of Uruvelā. As a symbol of the Buddha's victory, the ascetics cut off their matted hair, and they let their braids, carrying poles and devices of fire-worship be carried away with the river. The other two Kassapas $^{19}$ and all their followers also join the Buddha. The next step is to force the three to renounce fire-worship and false doctrines 
in public and in the presence of King Bimbisāra. The victory of the Buddha is complete.

Kassapa decides to fare the brahmafaring (brahmacariyam caritum) under the Buddha. All the matted hair ascetics, Kassapa of the River and Kassapa of Gayā, with all their followers, decide to follow his example. They cut their hair and let all their implements of fire-worship be carried away with the water. Such passages reveal a high degree of competition between the Buddha and other religious leaders. We may note here that the narration of the conversion of the Kāsyapas is more detailed in the Sanskrit, the Tibetan and the Chinese than in the Pāli version. Interestingly, they all give the Buddha's motive for approaching the Kâsyapas as the wish to subdue that religious leader in Magadha by which he can win over the greatest number of followers. This adds to the feeling of conversionism and competition.

MV I.23 provides the account of a competition with another religious leader. Sañjaya is staying in Rājagaha with his followers, among them Sāriputta and Moggallāna. The last two have agreed that whoever attains the deathless first shall tell the other. One day Sāriputta sees Assaji, one of the original followers of the Buddha, and he believes that Assaji has entered the path of perfection. Sāriputta follows Assaji on his alms-round in the town, waiting for a suitable opportunity to ask him about his teacher and his Dhamma. Assaji tells him in few words about the Lord and his Dhamma, and Sāriputta realizes that this is the path to perfection. He returns to his friend, Moggallāna, and announces the good news. In MV I.24 Sāriputta and Moggallāna decide to leave their group and join the Buddha instead. When they announce their plans to leave, the other followers of Sañjaya decide go with them. Sañjaya tries to make them stay, but he cannot change their minds. Hot blood comes out of Sañjaya's mouth and he dies. The Buddha sees the two friends coming in the distance and he predicts that they will be his most eminent disciples. Again the victory of the Buddha is complete. Indeed, the competition ends in the death of Sañjaya.

The clearest and most famous expression of the quest for converts is found in MV I.11, in which the Buddha tells the monks to walk out in the world for the welfare, blessing and happiness of devas and men and teach Dhamma, which is lovely at the beginning, lovely in the middle and lovely at the end. It is interesting to see this missionary ideal together with a statement in CV V. Here, the Buddha forbids monks to recite his speeches in metrical form and tells them to learn the word of the Buddha in their own dialect. 
These passages give the impression of a sect with a desire to convert that is reminiscent of Christian sects.

If we move from the Vinaya to the Sutta Pitaka, we find several examples of the conversionist quality of early Buddhism. In the Udumbarikā Sìhanādasuttanta of the Dìgha Nikâya, the Buddha clashes with the religious leader Nigrodha. In a long conversation, the Buddha tries to convince his opponent that his kind of asceticism is useless. This conversation is interesting because it reveals much about the relationship between the Buddha and other teachers. For instance, it seems that the Buddha has been charged with too intense proselytizeing. Concluding his speech on the uselessness of asceticism, the Buddha says:

Maybe, Nigrodha, you will think: The Samana Gotama has said this from a desire to get pupils; but you are not thus to explain my words. Let him who is your teacher be your teacher still. Maybe, Nigrodha, you will think: the Samana Gotama has said this from a desire to make us secede from our rule; but you are not thus to explain my words. Let that which is your rule be your rule still. ${ }^{20}$

One gets the impression that the success of the Buddhists is too much for the competing teachers and that the Buddha is used to accusations about ruthless missionary activity among members of other sects.

Another example of the uncompromising competition with nonBuddhists is the Ambatthasutta, in which the Buddha discusses pride of birth with a rude young Brahmin, Ambattha. Here, the Buddha asks questions about Ambatṭha's lineage to show that the young Brahmin's feeling of superiority is without foundation. Ambattha knows that the answer to the Buddha's question will be humiliating to himself, and he has a hard time answering. But the Buddha forces him to reply in a way which is typical for competitive debates:

If you do not give a clear reply, or go off upon another issue, or remain silent, or go away, then your head will split in seven pieces on the spot. ... At that time Vajrapāni stood above Ambattha in the sky with a mighty mass of iron, all fiery, dazzling, and aglow, with the intention, if Ambattha did not answer for the third time the question asked by the Lord in 
accordance with Dhamma, there and then to split his head in seven pieces. ${ }^{21}$

No wonder the Buddha often gets the answers he seeks from his adversaries. There are a number of passages in the Buddhist literature that reflect competition and envy between the different sects over their success in conversion. There also existed envy between the sects over material and spiritual support from the world. For instance, in the Udumbarikāsinhanādasuttanta of the Dìgha Nikāya, there is a quarrel between the Buddha and the religious leader Nigrodha. The Buddha explains to Nigrodha the blemishes of the ascetics:

And again, Nigrodha, an ascetic sees a certain recluse or Brahmin receiving attentions; being revered, honoured and presented with offerings by the citizens. And seeing this he thinks: The citizens pay attentions to this fellow who lives in luxury; they revere and honour him, and present him with offerings, while to me who, as ascetic, lives a really austere life, they pay no attentions, nor reverence, nor honour, nor offerings! $!^{22}$

Envy also arose between different Buddhist communities as the religion developed. In Ceylon under Vațagāmaṇi (43-17 BC) a split occurred between the Mahāvihāravāsins and the Abhayagirivāsins as a result of the king's personal gift of the Abhayagirivihara to the thera Mahātissa. ${ }^{23}$

Joy Manné has made a distinction between three types of suttas in the Sutta Pitaka: Sermons, Consultations and Debates. The competitive element in the religious life is expressed in the suttas that Manné has called Debates, especially the Dramatic Debate with its structure of a challenge, a refutation of the view of the adversary, and finally a defeat in which the adversary either asks to become a lay follower or is totally converted and asks to become a monk. In order to gain followers and converts, early Buddhism needed an initial message that was attractive and entertaining to people and which showed that the Buddha's Dhamma was better than that of other teachers. Typical examples are the Sonadandasutta, the Kassapasīhanādasutta and the Sāmaññaphalasutta. A Debate is an exercise in publicity, Manné says. 
It is an opportunity for propaganda. Something is always at stake. Not only must the best questions be asked, and the best answer given, but converts must be won and lay support must be gained. Under these circumstances we may expect that, appropriate to the situation, a particular presentation of the Teaching is given. We expect this to be religiously sound, but exaggerated, because the Debates were public competitive occasions. ${ }^{24}$

By the identification of a range of suttas in which the goal is the winning of converts, Manné demonstrates the conversionist quality of the early Buddhists.

\section{To introversionism}

Over the last few pages I have looked at the tendency in early Buddhism to compete with other religious groups for converts. The group that formed around the Buddha was constantly trying to recruit new members, and a large proportion of the converts were motivated by the prospect of status, material support and the escape from obligations in society. However, early in the life of the Samgha changes set in. When a sect withdraws from society and tends towards seclusion, Wilson calls the reaction introversionist. I will use this term to cover four important aspects of early Buddhism: the gradual development of strict admission procedures, the emphasis on unity, the mental segregation by outward appearance and the physical segregation by separate dwellings, i.e. the development of monasticism. In the following sections I will look at how the early Samgha's relationship to the world changed from conversionism to introversionism and how this change is reflected in the early Buddhist texts. My primary source is still the Khandhakas of the Vinaya Pitaka.

\section{Admission procedures}

The gradual development of the rules for admission to the Samgha is perhaps the most important element of the introversionist tendencies of the early Buddhist Order. The subject matter of the Pravrajyāvastu of the Skandhaka, which is found in Pāli from MV I.25, is the admission to the Samgha and the rules for newly ordained monks and novices. 
In MV I.28 the Buddha abolishes the ordination by going to the three refuges. Instead, he allows ordination by a motion and a resolution put three times. MV I.29 to 31 and I.31 deal with further restrictions on ordination. It is clear that the Samgha is reacting to a need to protect itself from members that destroy its purity and the aloofness. Many of the restrictions are the result of the ordination of persons whose motivations are purely mundane. The Samgha is closing its borders; it is becoming more introversionist in its relation to the world. Discussing the development of the ordination proceedings, Horner says:

Regulations have to increase to meet a complexity of emergent eventualities. The resources, nissaya, the minimum number of monks composing an Order competent to ordain, the number of years a monk must have been ordained before he is reckoned as suitable or competent to ordain others, living in dependence, nissāya vatthum, on a teacher, giving guidance, nissayam dātum, the qualities that a monk should be possessed of in order to ordain, and the ordination and probation of former members of other sects, and the age at which a person may be ordained, are all subjects brought under review. The inner life of the Order had to be safeguarded as much as had its relations to the world outside. ${ }^{25}$

The candidate also had to undergo a period of preparation and instruction between the preliminary admission and final admission. Horner suggests that this may be a way of dealing with the drawing power of the Buddhist Order. ${ }^{26}$

New offices in the Samgha are also introduced to keep control. Monks who do not have preceptors go for alms-food wrongly dressed and they behave wrongly. They are criticized by lay people so the Buddha allows a preceptor (upajjhayya). In MV I.25-27 the Buddha lays down a large number of rules about how the preceptor and the one who shares his cell should behave towards each other. In MV I. 32 and 33 a new office is introduced by the Buddha; that of the teacher (ácariya). This is an aspect of the growing organization of the Samgha. MV I.33 and I.34 give rules for the behaviour of pupils towards teachers and vice versa. MV I.35 also covers the relationship between teachers and pupils. MV I.36 and I.37 give a large number of instances in which a monk may or may 
not ordain. These are further steps towards stricter rules for admission.

MV I.38 details restrictions on the ordination of the former members of other sects. If a former member of another sect refutes his preceptor and returns to the other sect and later comes back to join the Samgha, he should not be ordained. Members of other sects who desire ordination in the Samgha should be given a fourmonth period of probation before ordination. This contrasts with, for instance, the episode of the matted hair ascetics in which the Buddha uses all his magical skills and humiliates the leader of the rival sect in his attempt to convert the ascetics to his teaching. The attitude towards the outside world and towards potential converts has changed. The Samgha is becoming more intent on defending its borders against people with the wrong motivation.

In MV I.39-48 thieves, murderers, debtors, runaway soldiers and sick and hungry people wish to join the Samgha as a way to solve their problems. Restrictions on motivation are laid down in order to keep them out. The Samgha must protect its purity from corruption. This concern with the purity of the group is a typical feature of the introversionist sect.

In MV I.49 the Buddha pronounces the rule that a man under 20 years of age should not be ordained, and in MV I.50 that a boy under 15 years old should not be allowed to go forth. These are important regulations contributing to the organization of the Samgha and the tightening of its borders. In MV I.51 the puzzling exception is made that a boy under 15 years old can be allow to go forth if he is able to scare crows.

In MV I.56-60 rules concerning novices are given by the Buddha. From MV I.61 more restrictions on ordination are given. MV I.64 and I.65 forbid matricides and parricides to be ordained. MV I.66 and I.67 forbid a murderer of an Arahant, a seducer of nuns, a schismatic or one who sheds the blood of an Arahant to be ordained.

In MV 1.69 the Buddha gives instructions that one who has no preceptor should not be ordained, nor should one who has an order as preceptor, one who has a group as preceptor, one who has a eunuch as preceptor, one who had one living in communion, as it were, by theft as preceptor, one who had one gone over to another sect as preceptor, or one who had an animal, a matricide, a parricide, a murderer of a perfected one, a seducer of a nun, a schismatic, a shedder of an Arahant's blood or a hermaphrodite as preceptor. 
Thus, MV I.69 lays down regulations to prevent further corruption of the Samgha by letting people who should not have been ordained in the first place act as preceptors.

In MV I.70 further cases in which one should not ordain are given. One who had no bowl was ordained. He received his almsfood in his hands. People were irritated because the newly ordained monks looked like members of other sects. One without a robe was ordained and he walked naked for alms-food. People were irritated because he looked like the members of other sects. MV I.71 gives instances of physical injuries or illness in which one should not be let go forth. One who had his hands cut off was ordained, one who had his feet cut off, one who had his ears cut off, one who was lame, one who was deaf, etc. Physical deformation is seen as a threat against the purity of the Samgha.

MV I.72 has instructions not to give guidance to the unconscientious and not to live under the guidance of the unconscientious. In MV I.73 the Lord allows monks to live without guidance under three circumstances: if one is travelling on a high road, if one is ill or if one is tending another who is ill and if one is staying in the forest. In MV I.75 the Buddha defines the age for ordination to be 20 years from conception. MV I.76-79 are further specifications regarding ordination; in MV I.76 the full ordination procedure is described.

\section{Unity}

A central issue in the development towards an introversionist relationship to the world is the emphasis on the unity of the Samgha. The unity of the Samgha seems to have been a primary expression of its purity. Let us look at the theme of unity in some of the later passages of the Khandhakas.

In MV X there is a story about dissensions. In Kosambī a monk is suspended because of an offence he has committed. He does not accept his suspension. He approaches a group of monks, who take his part against the group that has suspended him. Thus, a dispute arises in the Samgha. The Buddha tries to settle the dispute. He goes to Sāvatthi and stays in the Jeta Grove in Anāthapiṇ̣ika's monastery. Now the lay followers of Kosambi decide to put pressure on the trouble-making monks by withdrawing all their respect and offerings. The monks of Kosambī go to Sāvatthi in order to settle their dispute in the Lord's presence. The Buddha instructs the monks 
in Sāvatthi on how they should behave towards these monks. The monks arrive and the case is settled. The Buddha gives them rules on how disputes in the Samgha should be handled and how schism and dissension should be avoided. These passages illustrate the emphasis on unity and the necessity of settling disputes among the monks.

In CV I, monks who are followers of Panduka and Lohitaka cause strife in the Samgha. The Buddha gives instructions on how a formal act of censure (tajjaniyakammam) should be carried out against the followers of Panduka and Lohitaka. The Buddha tells the monks under what circumstances a formal act is valid and invalid. He tells them under what circumstances a formal act of censure should be carried out against a member of the Samgha and how a monk should behave after such an act has been carried out against him. Then follows the circumstances under which a formal act of censure should or should not be revoked and how it may be revoked. This chapter contains a number of other accounts of monks who come into conflict with the Samgha. In total, it details seven different formal acts to be carried out by the Samgha as reactions to different transgressions.

In CV III, the venerable Udāyin has committed an offence. He does not conceal his offence and he must perform penance (mānatta). Then Udāyin goes on to commit new offences, but now he conceals them for one day, two days, three days, etc. Again, he must perform mānatta, but only after a probation period that varies with the number of days for which the offence has been concealed. Then Udāyin commits a new offence during the probation period and later during the mānatta. A number of different combinations of offences - concealed or not, committed during probation or mānatta etc. - are described. The chapter is extremely detailed and repetitive in style.

CV II deals with the observances for monks who are under probation (parivāsa) and those undergoing mānatta. Upāli asks the Buddha questions pertaining to the subject. The point seems to be to make the monks under parivāsa and mānatta distinguish themselves clearly from the rest of the Samgha.

CV IX deals with the objection against participation in the Posadha ceremony. The Buddha is sitting surrounded by monks on an observance day but he is unwilling to recite the Pâtimokkha because the assembly is not entirely pure. Moggallāna sees the individual who is not pure and throws him out. Then the Buddha 
tells the monks about the eight strange and wonderful qualities of the ocean and eight strange and wonderful things in the Dhamma and discipline. He declares that he will no longer carry out the observance and will not recite the Pattimokkha; from now on the monks must do it themselves. He instructs the monks to suspend the Pātimokkha for listeners who have committed an offence. He goes on to describe the cases in which the suspension of the Pattimokkha is valid or not. In short, this chapter is about the purity of the Samgha, which is the central concern of introversionist sects.

$\mathrm{CV}$ IV is also concerned with questions of the purity and dignity of the Samgha in the eyes of monks and lay people. It contains stories about the venerable Dabba the Mallian, Gagga, who was insane and in his madness said and did unworthy things, and Uvāla, who tells a conscious lie while being examined for offences. There is great concern with how to settle disputes and problems in the Samgha. The unity of the sect is essential for its purity.

The issue of unity is elaborated in CV VII, the chapter on the split of the Samgha. Bhaddiya, Anuruddha, Ānanda, Bhagu, Kimbila, Devadatta and Upāli go forth in the Buddhist Samgha. Devadatta attains psychic powers and through these he is able to impress Prince Ajātaśatru. He becomes obsessed with the fame and respect that he gets through his powers and he wishes to become leader of the Order of monks. Devadatta suggests to the Buddha that he take over the leadership of the Samgha. The Buddha rejects this, saying that he would not even hand over the Order of monks to Sāriputta and Moggallāna, much less to the evil Devadatta. The Buddha instructs the Order to carry out a formal act of information ${ }^{27}$ against Devadatta.

\section{Appearance}

The appearance of the monks and nuns is a central concern in the Vinaya texts. This issue is essential because the dignity and aloofness of the monk is linked to how he looks and how he behaves. The thirty Nihsargika Pātayantika Dharmas of the Prātimokșasūtra are concerned with the robes and bowls of the monks. Wearing the right kind of robe in the right way is essential for the appearance of a monk. The Śaikșa Dharmas are very detailed rules for how to wear the robe (rules $1-18)^{28}$ and how to enter and sit in a layman's house (rules 19-61) and how to receive food (rules 63-88), and a number of rules on general appearance when dealing with lay 
people. It seems that the Śaikșa Dharmas where laid down in order to make the distinction between monk and lay follower clear and to make the monks appear serious, calm and dignified. The ninety Pātayantika Dharmas of the Prātimokșasūtra are also about the behaviour of monks. Typically, a monk must not be seen with a nun (rules 21, 22, 23, 24, 26, 27, 28, 30, 35) or with a laywoman (rules $30,43,65,70$ ), and he must eat in a proper manner (rules 34 , $36,37,38,39,40,41,42)$.

The subject matter of MV VIII is the monks' clothes. For an overview of the rules on clothing, the rules of MV VIII should be compared with the Nihsargika Pātayantika Dharmas of the Prätimokșasūtra. The chapter starts with the interesting account of Jīvaka Komārabhacca. The story of Jivvaka introduces the permission to wear robes given by lay followers. The Buddha becomes sick because of a disturbance in the humours of the body. Jivaka restores the health of the Lord and asks a favour. He asks the Buddha to allow the use of householders' robes for the monks. The Lord consents. Clothes of different materials are presented to the Order of monks. The Buddha allows six materials for robes: linen, cotton, silk, wool, coarse hempen cloth and canvas (MV VIII.3). A number of rules are given regarding the acceptance, storage, distribution and dying of robes. The Buddha walks with Ānanda from Rājagaha to Dakkhiṇāgiri. On the way he sees the fields of Magadha and he asks Ānanda whether he is able to make robes like the fields. Annanda makes robes and he receives applause and respect for his skill. Then follow rules on the number of robes allowed for one monk. The Păli Vinaya has the rules of the kathina in MV VII, that is, before the chapter on clothes and robe materials. The detailed regulation of this ceremony reflects the importance of appearance in the monks' interaction with the laity. All association must follow strict rules. If the rules are broken, the monks are punished.

In CV I the venerable Seyyasaka lives in company, and in unbecoming association, with householders. The Buddha tells the Order to carry out a formal act of guidance (nissayakammam) for Seyyasaka. Instructions on how, and under what circumstances, a formal act of guidance should be carried out are given. He also tells them how, and under what circumstances, an act of guidance should be revoked.

Monks who are followers of Assaji and Punabbasu in Kiṭāgiri engage in all kinds of bad habits. A self-righteous monk passes 
Kițāgiri on his way to Sāvatthi, where the Buddha is staying in the Jeta Grove in Anāthapindika's monastery. On behalf of the only decent lay person in Kitâgiri he reports the bad habits of the monks to the Buddha. The Buddha sends Sāriputta and Moggallāna to Kiṭāgiri to carry out a formal act of banishment (pabbājaniyakammam). Instructions are given on how a formal act of banishment should be carried out and how, and under what circumstances, it may be revoked.

In CV V monks use different kinds of begging-bowls made of precious materials. The Buddha allows the use of two kinds of bowls: iron and clay. A great number of rules concerning bowlrests and the treatment of bowls are given. Then follows a large number of rules pertaining to robes, then some rules about sandals, water-strainers, filters, mosquito nets, etc. Some rules are also given about bathrooms, pools and tanks.

CV VIII is exclusively concerned with the appearance of monks. Some monks enter a monastery in an unbecoming manner, so the Buddha lays down a custom for entering a monastery. Minute rules are also laid down for how to take off one's sandals, how to wipe them and dry them, how to wash one's feet, how to drink, how to carry a bowl and the robe, how to ask for lodgings in a monastery, how to make the bed, how to wipe the bed, how to move a chair, how to sweep the ground, etc. There are elaborate rules for how to behave in the presence of lay people. These repetitive passages are identical with passages in MV I.25. The very detailed prescriptions reflect a deep concern with decorum. The monk must make every movement in a controlled and proper manner. It is clear that the central issue is to appear calm and dignified. A few passages may demonstrate the concern for a pure and uplifted appearance. The monk should enter a village carefully and unhurriedly. The monk must go amidst the houses properly clad, well controlled, with downcast eyes, not lifting up the robes, without laughter, with little noise, etc. Alms-food should be eaten attentively and not cut into too large pieces, the whole hand should not be put into the mouth while eating, one should not talk with food in the mouth, etc. Rules like this cover large parts of the Khandhakas of the Vinaya Pitaka and they show the great emphasis that the Buddhist Samgha put on outward appearance both in the eyes of the world and in the eyes of the monks themselves. 


\section{Dwellings}

An important element in the Samgha's transition from a conversionist to an introversionist relationship to the world is the Order's dwellings - its spatial localization in society. In the beginning, the Samgha was a wandering lot. A typical feature of the life of renouncers is homelessness. The Buddhist renouncer is required to leave home to the extent that he does not even feel 'at home' in his own body. However, the Samgha soon became tied to place. In MV III.1 people criticize the sons of the Sakyans for walking around during the winter, the hot, rainy season, and trampling down crops and grasses and destroying many little creatures. In reaction to this, the Buddha allows the monks to enter upon the rains, meaning that they should stay indoors in one place during the rainy season. In MV III.2 he informs the monks of the two right times for entering upon the rains. In MV III.4 he forbids the monks not to enter upon the rains. This is the start of the Samgha's tradition of staying in buildings.

CV VI is about the dwelling places of the monks. Considering the subject matter of the chapter, one would perhaps expect to find CV VI, i.e. the Pâli version of the Śayanāsanavastu, among the other chapters on the day-to-day life of the Samgha at the beginning of the Khandhakas. Frauwallner suggests that it is found towards the end simply because life in monasteries became important at a later date. Thus, it is a reflection of the growing introversionist tendencies. In CV VI, the monks stay in forests and under trees, in the open air, etc. A merchant suggests that he build dwelling places for the monks and the Buddha allows this. Other people start building houses and a number of problems occur. The Buddha allows different kinds of devices - doors, windows, drapery - to keep snakes, rats, ants, etc. out and different types of furniture for the comfort of the monks. He also allows different ways of applying colour to the walls, the sleeping places and the ground. He allows assembly halls, porches, different kinds of fences, different kinds of roofs, etc.

Then the story of Anāthapindika is told. Anāthapindika goes to Rajjagaha to visit his wife's brother, who is a great merchant. In Rajjagaha he meets the Buddha and becomes a lay follower. $\mathrm{He}$ offers a meal to the Order of monks. When he returns to Sāvatthī he buys a pleasure grove belonging to Prince Jeta and makes a monastery for the Samgha. The Buddha and his Order stay at the 
Jeta Grove and Anāthapindika is instructed to prepare the Jeta Grove for the use of the Order. Problems arise over dwelling places and the Buddha instructs the Order to assign lodgings. A large number of rules are given concerning dwelling places. Problems arise over the distribution of food and so the Buddha instructs the Order to appoint an issuer of meals. He also instructs the Order to appoint monks to oversee a number of other functions concerning the daily life of the Samgha: lodgings, clothing and food.

To sum up, the rules that I have looked at under four headings testify to a change in the Samgha's relationship to the world. First, its borders were tightened in that the rules for admission grew stricter. Second, the emphasis on unity and the fear of Samghabheda was a typical aspect of the growing introversionist tendencies. Third, the interaction with lay people was regulated in detail and the segregation from the laity was expressed in the distinguishing and uniform appearance of the members of the Samgha. Fourth, physical borders were built in the form of monastery walls.

\section{Conclusion}

Let me sum up the conjecture of this chapter in a few sentences. Buddhism originated as a conversionist movement, which I took to mean that it emphasized proselytizeing activities and an open relationship to the world. The religious renouncers of India at the time of the Buddha enjoyed status and material support from the common people. Therefore, the sect of the Buddha attracted many individuals who were extrinsically motivated. When the outside world observed that a large part of the monks joined the Samgha for purely profane reasons, the status of the monks fell. This reaction of the laity is described again and again in the Khandhakas with standard phrases such as: 'People looked down upon, criticized, spread it about, saying: "How can these recluses, sons of the Sakyans ... etc." ("manussā ujjhāyanti khīyanti vipācenti: katham hi nāma samañā Sakyaputtiyā ...").'

If the Samgha had let its holiness and purity be corrupted by the wrong motivation of its members, the crucial material support and respect from the laity would have failed. To stay pure, both in the eyes of the world and in the eyes of the sincere monks, the Samgha had to strengthen its borders against the extrinsically motivated applicants. In order to stay aloof, the Order had to withdraw from the world, and the monks had to maintain a dignified and holy 
appearance. Introversionist tendencies developed. But these tendencies made the Samgha an even better object for lay support. The more introverted the Samgha became and the more its purity was emphasized, the more support it received. The less interest its members took in material values, the more attractive it became as an object of devotion and as a receptacle for offerings. Again, the growing support for and wealth of the Order led to a growing number of extrinsically motivated applicants for membership, which led to a need to withdraw and cultivate the purity of the Samgha. In his book on Theravāda Buddhism, Gombrich has described the dynamic in the following way:

The more a monk demonstrates his indifference to worldly comforts, the more he impresses the laity and comes to be regarded as worthy of their material support. Indifference to comforts thus causes them to be provided. ${ }^{29}$

This mechanism presupposes an Indian setting in which the status of the renouncer is high and there is a general belief in rebirth and karma and a need for gaining merit among common people. I have shown that this process is expressed in the early Buddhist literature and I will return to these ideas in Chapter 6.

I have suggested an explanation for the relationship between the Buddhist Samgha and the laity which emphasizes the unintended consequences of the behaviour of the members of the Samgha. Extrinsic motivation among the members and potential members of the Samgha leads to introversionism. Introversionism leads to more support from the laity. Support from the laity leads to extrinsic motivation. Thus, we have a self-enforcing mechanism. It is a virtuous circle, and in the historical periods when the Samgha has been able to maintain the balance it has led to a certain degree of stability in Buddhist societies. The structure of Theravāda Buddhist societies are the best example of this built-in conservatism. The crucial point in the circle is the introversionism, the constant need to bar the wrong people and to purify the Samgha by getting rid of lax and greedy monks. When the Samgha fails on this point, the mechanism turns around, and we end up with a vicious circle. The Samgha is seen as impure and lax, support from the laity fails, and the Samgha becomes less able to restore its purity. 


\section{RELIGIOUS MOTIVATION AND THE THEME OF CONVERSION IN BUDDHISM}

In the last chapter I used the terms conversion and conversionism in order to illuminate the religious motivation of the early Buddhists and their relationship to the early Samgha. Of course, it is always problematic to use terms and concepts that have very specific meanings in one historical context to describe the state of affairs in a very different setting. A critical discussion of the very idea of conversion and its applicability in a Buddhist context seems to be required in a study of the religious motivation of Buddhists and the social psychology of the relationship between Samgha and laity.

There is a discrepancy in the way that Buddhist texts present the conversion process of the Buddha and some other central figures, on the one hand, and the impression we get of the conversion process of people who were already part of the broader religious milieu of the period, on the other. The paradigmatic Buddhist conversion consists of the overwhelming realization that life is suffering followed by a dramatic break with life in the world to seek salvation. At the same time, however, we often get the impression in early Buddhist conversion stories that the people who joined the Buddha did not experience any personal crisis. They were already members of other religious movements and had broken all ties with the world long before they became Buddhists.

The solution to this discrepancy is to be found in the difference in the conversion processes of people with different social backgrounds. The individuals who went in and out of different sects at the time of the Buddha belonged to a large milieu of religious seekers. Therefore, the conversion took place not when they decided to join the early Buddhist Samgha but rather at the moment when they decided to leave worldly life and become religious wanderers. This is congruent with the life-story of the Buddha. His conversion 
resulted in his joining a number of different religious teachers before he decided to find his own way to salvation. The real conversion in this context takes place in the process of going from a life in the world to a life as a religious wanderer. Once that crucial step has been taken, people seem to have gone in and out of different religious movements without the emotional perturbation and the change in personality that is characteristic of conversion in the true sense of the word.

I have no ambition to give a new and original interpretation of early Buddhist conversions here. I simply want to make a point about the concepts we use when we seek to understand the rise of the first missionary religious tradition in the world: We should probably talk about conversion only in the cases in which ordinary people were induced to join the general and multifarious milieu of religious seekers and wanderers at the time of the Buddha. We cannot talk about conversions between these different movements. In fact, it is this movement as a whole, and its opposition to the wider world, which is most interesting from a sociological point of view.

Conversion is, of course, a Western idea and the word comes from Latin. Therefore, I intend to start out by looking at the central paradigm of conversion in the West, i.e. Paul's conversion on the road to Damascus. This paradigm tells us something important about the standard conception of conversion in Christianity, namely that it is brought about by an external agent and that the individual has little or no control over his or her own religious transformation. This deterministic view does not necessarily imply a belief in God as the external agent. In fact, this position has been developed by scholars in the social sciences, in psychology and even in sociobiology and I intend to make a very brief, and necessarily simplistic, detour into these variants of determinism before returning to the main focus of early Buddhism. In view of the dominant conception of conversion in Christianity, we must at the end ask whether we can gain a new and better understanding of religious conversion as a general religious phenomenon and as a crosscultural category for investigation by looking at Buddhist conversion stories. 


\section{Conversion and determinism: is the Pauline paradigm relevant to India?}

How can we understand the motivation of religious converts? In the social sciences, religious conversion has often been seen as an event in which the fate of the individual is determined by forces over which he or she has no control. In Acts $22 \mathrm{St} \mathrm{Paul} \mathrm{tells} \mathrm{people}$ about how he was converted. On his way to Damascus he saw a powerful light and he heard the voice of Jesus Christ speaking to him. He was temporarily blinded and led into the city. Paul had previously persecuted those who believed in Jesus. Indeed, the goal of his journey to Damascus was to lead some Christians to Jerusalem to have them punished. But on this day, on the road, Paul was converted suddenly and dramatically. He was converted by an external agent. Jesus had approached him and called him to his service. Paul was the passive receiver of his religion; he did not seek it.

The conversion of St Paul has long been the paradigm of conversion. ${ }^{1}$ The most obvious reason for this is to be found in the nature of Christianity. First, at least since St Augustine belief has been something that is offered to man or bestowed upon him from outside. Man can prepare himself intellectually, but God's grace is essential to reach real belief and understanding. Man is the passive subject and St Paul's conversion on the road to Damascus is the typical example of this receiving role. Second, the Pauline view of conversion has been compatible with a scientific and non-religious approach to the subject: Both views hold that a person does not arrive at religiosity by rational means. Consequently, a person must be coerced by external agents in order to undergo conversion. (This view of conversion is akin to the popular view of communists as being brainwashed. ${ }^{2}$ The inherent falsity of their beliefs proves that they have been subject to brainwashing; false doctrines are accepted only when forced upon a person.) Third, one could look for a connection between the Pauline paradigm and the debate in social sciences over the importance of the situation vs. the importance of consistent traits of individual behaviour. The following is a good summary of these two opposing positions in scholarship:

One theory emphasizes the instinctual character aspect of humans, another the social; one theory stresses free will, another determinism; one theory views the person as an 
organism that reasons, chooses and decides (rational view), another views the person as an organism that is driven, compelled, irrational (animal view); one theory views the person as automatically responding to outside stimuli (machine view), whereas another views the person as processing information like a computer (computer view). ${ }^{3}$

Clearly, the Pauline paradigm would be looked on more favourably by situationalists, i.e. social scientists who emphasize the lack of behavioural consistency in the individual and the great power of the situation, than by those who believe in stable traits and emphasize the evidence for cross-situational consistency. ${ }^{4}$ These opposing views are favoured by different scholars, and trends may increase or diminish the credibility of each approach:

Although the Freudian and the Skinnerian views may represent extremes that many psychologists avoid, most psychologists nevertheless weight their theories in the direction of internal or external factors. Periodically there is a shift in emphasis from internal to external factors or vice versa, with an occasional call for investigation of the relationship between the two.... More recently, debate concerning the role of internal and external forces in governing behaviour has been highlighted in the person-situation controversy. ${ }^{5}$

It is quite clear that the general view of religious motivation, especially among American psychologists of religion, is influenced by the passive view of conversion, which, following James Richardson, I have called the Pauline paradigm. The conversion of the members of sects is very often discussed as something irrational and determined. The individual is basically seen as the locus for convergence of social forces.

But in addition to sociological and psychological determinism, there is a biological determinism, which claims to be sufficient to explain human behaviour, including religious conversion. It is now more than 25 years since Edward Wilson's book Sociobiology: The New Synthesis was published. The book started a heated debate in academic circles, which seems to be having a renaissance these days. The main reason for the high temperatures is that sociobiology presents a view of human nature that is not in any way compatible 
with the ideas of human nature that are the foundation of the hermeneutic disciplines and, to some extent, the social sciences. Another reason is sociobiology's somewhat imperialistic relation to the other disciplines that study human behaviour and human culture. Wilson said:

It may not be too much to say that sociology and the other social sciences, as well as the humanities, are the last branches of biology waiting to be included in the Modern Synthesis. ${ }^{6}$

According to Wilson, religious phenomena should ultimately be explained by sociobiology:
Although the manifestations of the religious experience are resplendent and multidimensional, and so complicated that the finest of psychoanalysts and philosophers get lost in their labyrinth, I believe that religious practices can be mapped onto the two dimensions of genetic advantage and evolutionary change. ... By traditional methods of reduction and analysis science can explain religion ... ${ }^{7}$

Needless to say, I believe that Wilson and other sociobiologists are wrong. They will never be able to explain religion, or any other specific culture-pattern for that matter, because their level of explanation is bound to be far too general. Biological factors are, of course, general constraints that determine the range of possible actions in any given situation but they cannot explain in any meaningful sense the specific actions that a human being chooses to follow. The idea that all human behaviours should be reduced to products of natural selection and explained in terms of genetic fitness is, of course, a direct and deliberate challenge to the autonomy and integrity of human culture. Most practitioners of the hermeneutic or humanistic sciences (der anderen Hälfte des globus intellectualis, as Dilthey called them $)^{8}$ wish to see human beings as the main protagonists in their own lives and they abhor the suggestion that life is determined, in the strongest sense of the word, by 'external' factors.

The trend in the social sciences has oscillated between the view that the situation is all-powerful and the view that emphasizes the individual's ability to control his or her own life. A shift is taking 
place in the way social scientists view religious conversion. A decade ago Richardson traced the emergence of a trend within social psychology and sociology that rejected the mechanistic view of the human being. He wrote:

It is within this broad, more humanistic tradition in sociology and social psychology, but also somewhat independent of it, that a new paradigm has begun to develop. Recent work on new religious movements by some sociologists, social psychologists, and a few psychologists and psychiatrists has helped produce an alternative view of conversion and induction into the new religions consonant with this paradigm. ${ }^{9}$

Clearly, this activist perspective should be considered prior to the hard theories of social science in the study of the religious motivation in early Buddhism.

\section{Conversion between the sects?}

From the extant literature it is evident that many of those who decided to join the following of the Buddha were high-caste and well-off people. ${ }^{10}$ Many of them were already in the process of religious seeking when they encountered the Buddha or came under the influence of his ideas. In fact, according to the standard account of the foundation of Buddhism, all the earliest followers were actively seeking some form of religious goal before they met the Buddha. For instance, the five monks who came to be the first members of the Samgha had formerly practised meditation with the Buddha. The Kassapas were matted hair ascetics before the arrival of the Buddha; they had long ago abandoned life in the world for the life of religious seeking. Sāriputta and Moggallāna, the most prominent disciples of the Buddha, were members of the sect of Sañjaya.

Here we are approaching an important subject closely connected with the activist view of conversion - a subject which might deprive the term conversion of its essence in the context of early Buddhism. If it was the case that many of the early members of the Buddha's following originally belonged to other sects or in some way were already on the path of religious seekership, are we justified in saying that they were converted? Did the joining of the sect of the Buddha really imply a fundamental change in their lives, a radical turning 
away from the shadows on the wall of the cave towards the truth? In other words, is the Pauline paradigm, the sudden conversion as the result of external factors, applicable at all in the case of early Buddhism?

In a study of a UFO cult, Balch and Taylor write that the joining of the cult was not a difficult or fundamental transition at all:

Before joining Bo and Peep [i.e. the leaders of the cult], members of the UFO cult had organized their lives around the quest for truth. Most described themselves as spiritual seekers. ${ }^{11}$

The material changes were not great for those who joined:

Although a significant number of cult members had given up
good jobs and comfortable homes to join the cult, most had
not. For some of the younger members, the material aspects of
life in the cult were not very different from what they had
experienced before they joined. ... Even those who made
substantial material sacrifices to join were not strongly attached
to their possessions. ${ }^{12}$

Nor was there any change of basic beliefs on the part of those who joined because they already belonged to a cultic milieu with a common metaphysical world view: 'Although Bo and Peep's message sounded bizarre to practically everyone who read about it in the newspapers, it was firmly grounded in the metaphysical world-view. ${ }^{13}$ In short, in most cases there was no conversion.

There is a similarity here with the sect of the Buddha as it is described in the Buddhist literature. As pointed out earlier, the five monks in the deer-park did not change their lifestyles radically when joining the Buddha, nor did the matted hair ascetics, nor did all those who went over from other sects, such as Sāriputta and Moggallāna, who initially belonged to the following of Sañjaya, nor did General Sīha who was a Jain. On the contrary, it is clear from the texts that a large number of those who joined the early Samgha were already part of a large religious and philosophical milieu of homeless wanderers. ${ }^{14}$ Some of the early Buddhists had to modify their meditational practice, their outward appearance or their diets, but their situation as religious seekers and wanderers did not change. In many cases, the basic elements of the lives of the early converts probably did not undergo the radical 
transformation that characterizes conversion. The question is, therefore, whether one is justified in talking about conversion to the Buddhist Samgha at all. ${ }^{15}$

As we saw in the previous chapter on the conversionist tendencies of the early Samgha, the early Buddhists tried to win followers in a number of ways. We also saw from the testimony of the Sämaññaphalasutta and many other texts that there appeared to be a high degree of competition among the different sects and their leaders and that people tended to go in and out of the different sects as it suited them.

Of course, I am not arguing that the different movements at the time were exactly the same, nor am I saying that it was a completely unproblematic affair to change sectarian affiliation. The Mahāvagga I.38 gives restrictions on the ordination of the former members of other sects. If a former member of another sect refutes his preceptor and returns to the other sect and later comes back to join the Samgha, he should not be ordained. Members of other sects who desire ordination in the Samgha should be given a four-month period of probation before ordination. In other words, there were clear borders between the different movements. But these rules are also a strong indication that there was quite a lot of traffic between the different religious movements. People listened to debates between leaders and chose their group on the basis of arguments and, of course, on the basis of the general status of a leader or a group in wider society. It was not a terribly dramatic thing to go from one sect to another. It was, in many cases, a process of debating and reasoning.

\section{Religious motivation and the decision to leave the world}

According to Dutt's assertion in his overview of the early spread of Buddhism, the Buddha had to convert his recruits from other religions. ${ }^{16}$ It is relatively easy to subscribe to this kind of matterof-fact statement if we forget to examine the concepts that we use to describe the world. Is it meaningful to talk about conversion from other religions in this context? Of course, there are a number of stories about fierce debates between Buddhists and the leaders or members of other sects but these are almost always rational discussions. If the opponent decides to become a Buddhist it is because he is convinced by argument, not because he is overwhelmed by some sudden religious realization. He is not converted. 
According to the Buddha biographies certain sights or omens made the Buddha-to-be renounce his life as a prince and take up the life of a religious wanderer. These sights made the young prince aware of the problem of birth, ageing, sickness and death, and this scared him. These four - birth (jāti), ageing (jarā), sickness (vyādhi), death (marana) - are all causes of samvega (samvegavatthu) according to Buddhaghosa. I will return to the important concept of samvega in the next chapter. This fear is the core of Siddhärtha's religious motivation. When he is told by his charioteer that he will grow old, become sick and die like the people he sees, he is terrified. Canto 3:37: 'This being so, turn back the horses, charioteer; go quickly home again. For how can I take my pleasure in the garden, when the fear of old age rules in my mind?' It is clear from the Buddhacarita and from the other biographies that what causes the prince's perturbation, his samvega, is the realization of the inherent suffering of life.

Thus, not only in the biography of the Buddha himself does the dissonance between expectations and attitudes derived from a pleasant and protected life, on the one hand, and the harsh realities of the world, on the other, appear as a motivational factor, a cause of samvega. However, these stories are elaborated and to some extent, of course, purely legendary. They are interesting primarily as a highly formalized illustration of a sequence of events leading up to a person's religious motivation. Still, I believe that they hold a significant truth, namely that conversion in the context of early Buddhism, and other contemporary soteriological movements for that matter, took place only when people decided to leave the world and join the milieu of religious wanderers.

We can make this point a little more realistic by bringing it closer to our own times. In his study of a doomsday cult John Lofland writes about tension as a motivating factor in the joining of the cult. He defines tension so that it clearly would include cognitive dissonance, although he does not use this term: 'This tension is best characterized as a felt discrepancy between some imaginary, ideal state of affairs and the circumstances in which they actually saw themselves. ${ }^{17}$ In other words, there are clear parallels between Lofland's description of a modern religious movement and the accounts we find in early Buddhist literature. Significantly, Lofland emphasizes that the psychological tension that was present in all the subjects in his study before conversion cannot explain why they chose to join the cult in question. ${ }^{18}$ Lofland observes that all 
those who joined the group had experienced tension and that this tension was a necessary condition for joining a sect. However, a number of other elements must be present. For example, first of all, the converts would go through a state of religious seekership, which implies that conversion is preceded by volition and conscious searching.

We should look for the same kind of volition and conscious searching in early Buddhist converts, but from the accounts that the Buddhist texts themselves present us with there is clearly a case to be made for a degree of determinism too. From the Buddhist point of view, external motivational factors were often important in the early converts to Buddhism. Gokhale has analysed monks and nuns of the early Samgha on the basis of the Theragāthās and Theri $g \bar{a}$ thās. Many of them are said to be able to recall the immediate reason for conversion. Gokhale classifies the reasons under a few main headings and he gives the number of monks and nuns who can be classified under each heading:

1 The impact of the personality of the Buddha accounted for $43 \%$ of conversions.

2 The impact of the personality of one of the leading disciples accounted for $24 \%$ of conversions.

As we are approaching the conclusion to this chapter, then, it seems increasingly difficult to answer the basic question of internal versus external factors in the conversion process: Is the Pauline paradigm relevant for Buddhism?

\section{Conclusion}

I started this chapter by saying that there is a discrepancy in the way that Buddhist texts present the conversion process of the Buddha and some other central figures, on the one hand, and the impression we get of the conversion process of people who were already part of the religious milieu, on the other. The paradigmatic Buddhist conversion is the rapid and overwhelming realization that life is suffering and the following dramatic break with life in the world to seek salvation.

I have argued that there is an important distinction between the conversion processes of people with different social backgrounds. 
The individuals who went in and out of different sects at the time of the Buddha belonged to a large milieu of religious seekers. Therefore, the conversion took place not when they decided to join the early Buddhist Samgha but rather at the moment when they decided to leave worldly life and become religious wanderers. This solution is also congruent with the life-story of the Buddha. His conversion resulted in his joining a number of different religious teachers before he decided to find his own way to salvation. The real conversion in this context takes place in the process of going from a life as gahapati to a life as a wanderer. Once that crucial step had been taken, people seem to have gone in and out of different religious movements without the emotional perturbation and the change in personality that is characteristic of conversion in the true sense of the word.

We should now return to the question at the beginning of this chapter and ask whether we can gain a new and better understanding of conversion as a general religious phenomenon and as a crosscultural category for investigation by looking at Buddhist conversion stories. What does the paradox that we have identified in these stories tell us about conversion in general? Clearly, it shows us the importance of understanding the socioreligious background of an individual who joins a religious sect. Conversion implies movement and we cannot hope to understand it without thoroughly examining both the place of arrival and the place of departure in each instance. Many of the early Buddhists arrived from a state of religious seekership that was extremely close to Buddhism: there was very little movement. The word conversion seems to be inappropriate in these cases.

But in a broader perspective, the early Buddhist conversion stories are particularly interesting precisely because they contain opposing conceptions of conversion. These stories testify to the great importance of both external and internal factors in the conversion process. They speak of the great importance of the strong and charismatic leader, or sometimes other powerful external factors, and at the same time they speak of the importance of the rational faculties of potential followers. The study of these conversion stories may therefore contribute to deepening our understanding of conversion as a complex process that may express itself on many points along a sliding scale of volition and determinism, even in one individual. 



\section{SOCIAL PSYCHOLOGY AND THE RELIGIOUS MOTIVATION OF THE EARLY BUDDHISTS}

The basic argument of this book is that in order to understand why a religion comes into being we should devote more attention to the religious motivation of individuals than is usual in the study of religious history. In this chapter, I wish to explore how some central theories from social psychology may contribute to our understanding of religious motivation in early Buddhism.

Up until the 1950s theories of motivation were dominated by drive theory, both in mainstream psychology and in the psychoanalytic tradition. Much of psychoanalytic thought is still permeated by the idea that the need to satisfy drives is the basic motivating force in human life, and sex and aggression are often prominent candidates in the explanation of behaviour. On the other hand, there is an important tradition of research in motivation that has abandoned the cruder forms of drive theory and seeks to explain human behaviour from a number of different angles. I wish to explore to what extent the findings of this tradition can be applied to explain why people chose to follow the movement of the Buddha and, thus, why Buddhism came into being. In doing so I have no intention of presenting a total picture of the vast field of motivational research nor of giving any definite answers with regard to my particular object of study, early Buddhism. From motivational theory I will pick an approach that sees psychological incongruity, the discrepancy between an internal state and an external stimulus, as a basic motivating factor, and from this general approach I will pick two more specific conceptualizations of motivation, namely, the theory of cognitive dissonance and a theory of secondary control. I should emphasize again that I do not believe that the exercise of applying these theoretical constructs to early Buddhist textual material will render radically new answers to the question of why 
Buddhism arose. My aim is, first of all, to open a discussion about the use of modern psychology in the study of ancient and alien religious traditions.

\section{Psychological incongruity}

A large body of psychological research has shown that people need a certain complexity in their stimuli, a certain challenge from the environment. If the incongruity between the environment and the standard of reference is too small, people will seek a more challenging situation. If the challenge is too great they will avoid it and seek a situation that corresponds to a higher degree with their standard of reference. There are, in particular, two conceptualizations of psychological incongruity that I will look at in this chapter. First, there is Festinger's famous theory of cognitive dissonance. ${ }^{1}$ I will apply this theory to understand the motivation of the members of the early Samgha. Second, I believe that research and theory on perceived control can be useful for the understanding of religion. I will apply the theory of Rothbaum et al. ${ }^{2}$ and view early Buddhism as an attempt to gain control indirectly over an unpredictable world by gaining insight into reality and changing one's cognition of the environment.

However, before I apply these two theoretical constructs to my material I wish to point out that the need to avoid incongruity between the individual and the world is a subject that is not limited to psychology. For instance, sociologists of knowledge approach the same basic need to harmonize the internal world with one's perception of the external world from a different angle and with a different terminology. Transformations in a person's worldview are seen as an adaptation to the environment. These sociologists have also put religious motivation in the context of such needs to adapt subjective reality to the objective world. ${ }^{3}$

Most of the time people are able to safeguard a necessary degree of symmetry between objective and subjective reality by procedures of reality maintenance. Subjective reality is maintained through the normal interaction with the institutions of society and through interaction with other people. But when the subjective reality that the person has received through socialization and internalization can no longer be maintained in the face of the external world, the subjective reality must be radically transformed in order to be in harmony with objective reality. And because in the history of 
humankind religion has served to validate and define reality, because religion has provided the crucial link between objective and subjective reality, a transformation in subjective reality often means religious conversion. The convert is re-socialized and must accept the subjective world that is given to him or her by the new community, and the past is often interpreted in the light of a new internalized truth. Thus, religious conversion is an alternative strategy when the individual is no longer able to maintain consistency between perceptions and inner structure of belief and values through normal adjustment.

Buddhism, along with a number of other sects, was a reaction against beliefs and values that were no longer in harmony with a society undergoing drastic and rapid change. At the time of the Buddha the society or societies of northern India were undergoing great changes. The Brahminical tradition could not satisfy the religious needs of a considerable proportion of the population, particularly in the growing towns. A number of sectarian leaders as attested by the Sämaññaphalasutta and other texts - appeared on the scene to offer new and more credible banners to the people. At the time of the Buddha four great kingdoms, Avanti, Vatsa, Kosala and Magadha, were growing. At the same time parts of the population of the sixteen great countries (mahäjanapada) organized themselves into chiefdoms, ganasamghas, with councils and assemblies. Other janapadas supported kings. The chiefdoms were ruled by ksatriya lineages and there was a sharp demarcation between the ruling families and the people who worked for them as employees or slaves. Cities grew as commercial and political centres. Industries grew in the cities and a monetary system developed.

In addition to soldiers, ministers, and religious officials employed by the kings there were money-lenders, medical practitioners, potters, weavers, dyers, reed- and leaf-workers, leather-workers, architects, smiths, hunters and butchers. The urbanization and the proliferation of trade and industry, not to mention the maintenance of communities of mendicants, required a considerable agricultural surplus, and some scholars attribute the advancement in agricultural techniques to the use of iron. Irrigation was also a central element in agricultural development and thus a significant variable in the social change.

The climate of the Ganges plain must have been warm and wet, and both the jungles that were gradually cleared and burnt and the 
muddy fields that were created must have provided close to perfect living conditions for a number of different parasites and insects that served as carriers of maladies, as pointed out by Gombrich. ${ }^{4}$ People probably lacked resistance to the diseases of this environment that they had inhabited for only a few generations, and the Buddhist literature contains passages about the threat of sickness. In the Mahāvagga of the Vinaya Pitaka (MV I.18) a number of people join the Samgha because they are afflicted with different diseases and are in need of treatment. In the Theraga $\bar{t} t h \bar{a}$ 55 we are told that Añjana joined the Buddha as a result of a panic in the Vajjian territory. The people of the area are said to have been afraid of three things: drought, sickness and evil spirits. According to this text, the Buddha quieted the panic, and it seems that it was the Buddha's ability to ease the fear that made Añjana join the Order of monks. On the other hand, it seems that the quality of life had improved for a large number of people during this period. Luxury goods, such as salt, pottery and textiles of different sorts, became available and the material culture improved in general. The successful gahapatis could invest part of their earnings in business and thereby augment their wealth. As Thapar says: 'There is evidence of an improvement in living conditions ...'.5

To sum up my steps so far, I am trying to outline an analysis of a religious transformation by emphasizing the importance of three elements in the explanation. First, we have the social situation in which the religious transformation took place. Second, we have the religious movement: Buddhism. I have suggested that Buddhism was a reaction against a state of incongruity between objective reality and the subjective reality of a large number of people at the time. These two standards needed to be synchronized. Faced with the inability to adjust in the normal, step-by-step process of modification of subjective reality, people embraced the solutions offered by a few charismatic leaders who were able to define the problems and point the way out. It was a switching of worlds, the cutting of the Gordian knot of the consistency problem, a throwing away of all traditional religious banners. With these two elements we describe the origins of Buddhism in a way that has been done by previous historians. The attempt here to offer a new understanding of this process is defined by the contribution of a third element in the explanation: motivation conceptualized as psychological incongruity. To do justice to the individual convert and to obey what I would call the motivational imperative, one 
should try to describe the causal mechanism going from the starting point (social conditions), through the individual, to the reaction (religious movement).

\section{Cognitive dissonance and religious motivation}

My argument is that a basic religious motive for the earliest Buddhists was a need to reduce an incongruity between their own inner structure of beliefs, attitudes and values, on the one hand, and an external world experiencing rapid change, on the other. The theory of cognitive dissonance was formulated by Festinger in 1957. ${ }^{6}$ Basically, Festinger believed that cognitions can stand in different relations to each other. First, two or more cognitions can have a consonant relationship, they are harmonious, or one follows from another. Second, cognitions can have an irrelevant relationship. Finally, cognitions can have a dissonant relationship. When a person has cognitions that stand in a dissonant relationship, it causes discomfort, which motivates him or her to reduce the dissonance between cognitions and achieve consonance.

Let us look briefly at how the theme of cognitive dissonance is reflected in early Buddhist literature. I mentioned earlier that according to the Buddha biographies there were certain sights or omens that made the Buddha-to-be renounce his life as a prince and take up the life of a religious wanderer. The realization of birth (jāti), ageing (jarā), sickness (vyādhi) and death (marana) were the causes of samvega (samvegavatthu). On three pleasure excursions outside the palace he saw an old man, a sick man and a corpse. These sights were illusions created by gods in order to bring about a disturbance in the mind of the prince. In Canto 3.4 we are told that his father, the king, was aware of the distressing sight the world might present, and he forbade the appearance of afflicted common folk on the royal road.

The Sanskrit word denoting religious perturbation here is samvega. We have encountered this word in earlier chapters. It is a noun made from the root sam-vij which means to tremble or start with fear. The translator E. H. Johnston explains the term in the following way:

Samvega as a religious term denotes the first step towards conversion, when the perturbation of mind is produced by 
something and leads to consideration of the inherent rottenness of the world and so to the adoption of the religious life. ${ }^{7}$

What the king is afraid of, then, is his son's conversion, his adoption of the religious life. In order to protect his son from the distressing sights of the world he clears away those whose limbs were maimed or senses defective, the aged and the sick - but to no avail. The prince is destined to become a Buddha. The term samvega occurs several times both in the Pâli canon and in Buddhist texts in Sanskrit. Through the discussion of cognitive dissonance and samvega I am trying to address a problem of how to analyse the religious motivation of early Buddhists with the language of psychology. This is an instance of a general problem in the study of religions. How can we describe a religious movement in a language that does not belong to that movement or to the culture in which it arose? In the words of Milton Yinger:

A serious difficulty associated with virtually all efforts to measure religion is the limitation of the dimensions or scales to one or to a few closely related religious traditions. This puts serious limits on any efforts to develop generalizations about the relationships of religion and society that are capable of being applied across cultural lines and across time periods. Measurements having crosscultural validity must abstract from specific social and cultural systems those qualitites that are intrinsic to the phenomenon of religion whatever the form of their expression. ${ }^{8}$

The sociology of religion must shun categories dictated too specifically by the characteristics of a particular theological tradition and must develop categories that facilitate cross-cultural comparison. Observing phenomena in real life, the scholar must conceptualize ideas in the language and form of expression used by the community in which the observations are being made. Later, he or she must present the observations in terms that are shared by the community of scholars, terms that are abstracted from their particular context and that make comparisons across cultural and temporal boundaries possible. In this leap the discussion of reductionism becomes relevant. The transformation of communicative experience to data for scientific investigation must contain an arbitrary element. However, this does not mean that we cannot 
do our best to construct analytical categories that correspond as far as possible with the concepts used by the participants of the religious life themselves. The now so familiar idea that the scholar's task is to bridge the gap between experience-near and experiencedistant concepts - between inside and outside, subjective and objective, emic and etic - is just as essential to traditionally hermeneutical disciplines as to the social sciences. Gadamer pointed out that it is madness for the historian to try to leave out his or her own concepts in the study of a historical epoch or tradition. ${ }^{9}$

I am suggesting that in samvega and cognitive dissonance we may have a pair of concepts - one used by the early Buddhists themselves and the other by Western psychologists - that can be applied to bridge the gap between the experience-near and the experience-distant, the subjective and the objective, in the study of the religious motivation in early Buddhism. Let me investigate this possibility a bit further.

It is clear from the Buddhacarita and from the other biographies that what causes the prince's perturbation, his samvega, is the realization of the inherent suffering of life. But what makes this realization so powerful in the case of the prince is the dissonance between his original cognition of his own life and this new knowledge that he himself must grow old, suffer and die. The sight of sickness, death and old age does not have this enormous impact on others whose previous ideas of life converge to a greater degree with the facts. His father, the king, for instance, is a realistic man. His ideas of his own life are in harmony with the objective truths of life. Canto 2:34: 'He did not, like one wanting in self-control, indulge in the pleasures of the senses, he cherished no improper passion for women, with firmness he overcame the rebellious horses of the senses, and conquered his kinsmen and subjects by his virtues.' Canto 2:38: 'He spoke what was pleasant and not unprofitable; he stated what was true and not disagreeable; for selfrespect made him unable to say even to himself a pleasant falsehood or a harsh truth.'

In contrast, the prince has lived a life of pleasure, hidden behind the walls of the royal abode, and the discrepancy between his cognition of his own life and the unavoidable facts of the world is overwhelming. This cognitive dissonance gives the prince a strong feeling of discomfort, which motivates him to equalize the discrepancy. Obviously, the facts of life cannot be changed, and the only solution is to bring his own life into some sort of harmony with these facts. 
The reaction of the young prince is extreme. His father has managed to achieve harmony between his life as a king and the facts of the world by choosing a realistic middle way between the pleasant falsehoods of imagined immortality and indulgence in the pleasures of the senses, on the one hand, and the harsh truths of suffering and death, on the other. The young prince rejects everything; his family, his amusements, his wealth and the duties of his social standing. The Buddha is essentially what William James called the sick soul:

Make the human being's sensitivity a little greater, carry him a little farther over the misery-threshold, and the good quality of the successful moments themselves when they occur is spoiled and vitiated. All natural goods perish. Riches take wings; fame is a breath; love is a cheat; youth and health and pleasure vanish. Can things whose end is always dust and disappointment be the real goods which our souls require? ${ }^{10}$

\section{Insight and secondary control}

In his study of the Śrāmanyaphalasūtra Graeme MacQueen distinguishes a few major themes in the text. ${ }^{11}$ One of these major themes he calls 'Internal and External Mastery'. This is a common theme in early Buddhist literature as well as in the literature of other Indian traditions. The figure of the king symbolizes external mastery and the figure of the sramana, sometimes the Buddha himself, symbolizes internal mastery. The conflict between the two roles is also seen in the Buddha biography in which the child is predicted to become either a cakravartin - i.e. an all-conquering king - or a Buddha. MacQueen illustrates his point by analysing the Khantivādi Jâtaka in terms of the dichotomy between external and internal mastery. In this Jātaka, a king cuts a peaceful ascetic to pieces with his sword in a fit of anger. The complete control and calmness of the ascetic is sharply contrasted with the wrath of the king. In the Śrāmanyaphalasūtra, King Ajātaśatru is overcome with fear. The reason for his fear is the silence of the large company of monks who are staying in Jīvaka's mango grove. In the same way it is the superior calmness of the ascetic that causes King Kalabu's anger to grow out of proportion in the Khantivādi Jätaka. In other words, it is the kings' inability to understand and believe in inner 
mastery and peace that is the reason for their agitation. To be faced with silence is to be forced to look inward, and for the parricide Ajātásatru introspection is not very pleasant. According to MacQueen, Ajātásatru's questions about the visible fruits of the life as a sramana further show his inability to understand anything apart from external, material values. The fruit of the life of the sramana is exactly the complete internal mastery that is embodied in the assembly of monks before him.

Several of the classical writers in the study of religion have touched upon the human need to control external events. Spinoza, Hume, Frazer, Radin and Malinowski all observed that religion was born as the individual tried to cope with more or less uncontrollable aspects of the world. I wish to continue this discussion of the applicability of the idea of psychological incongruity to understand the religious motivation of early Buddhists by introducing the concept of secondary control.

In the psychological study of perceived control it is often assumed that inward behaviours - passivity, withdrawal and submissiveness - are signs that show that a person has given up hope of control over factors that affect his or her life. Rothbaum $e t$ $a l$. have shown that such behaviour can better be understood as an alternative way of gaining control. ${ }^{12}$ The primary way for a person to exert control is to act on the environment and control aspects of the world by outward behaviour. Instead of seeing inward behaviours as a sign of relinquished control, such behaviours can be expressions of a secondary way of exerting control. This secondary control means bringing oneself into line with the environment instead of bringing the environment into line with the self. It is this secondary control that Gautama chooses by becoming a Buddha instead of a cakravartin. The renouncer's way of overcoming psychological incongruity by changing the self is the opposite of the violent strategy chosen by King Kalabu in the Khantivāda Jātaka and King Ajātasatru in the Śrāmanyaphalasūtra. Through meditation and other practices the religious mendicants manipulate their own feelings and attitudes to make them correspond with the facts of life and death. The kings, on the other hand, manipulate the environment to fit their feelings and attitudes. There is a parallel here with Festinger's theory that attitudes change to fit cognitions of reality, as discussed above.

Rothbaum et al. distinguish between four main types of secondary control. One of these types - interpretive control - I 
find particularly apt to contribute to the understanding of the psychology of early Buddhism because the wish to understand, to gain insight into reality, is a very important aspect of the road to salvation in Buddhism. A substantial part of the power of the Buddha was his superior insight or knowledge. For the Buddha, salvation consists of awakening to the ultimate truth. What the Buddha offers his followers is first of all an interpretation of the nature of existence $(d u k k h a)$, the knowledge of the origin of this state (dukkhasamudaya), the consolation that this situation can be ended (dukkhanirodha) and the way that will end the state of suffering (dukkhanirodhagāminīpatipadā).

In the words of Rothbaum et al.: 'Interpretive control refers to the search for meaning and understanding. ${ }^{13}$ Interpretive control fits with our general discussion of psychological incongruity as a source of religious motivation. It is another way of seeing the search for consistency or symmetry between external conditions and internal states, as Rothbaum et al. observe: 'The studies on interpretive control indicate that, rather than changing the world persons sometimes attempt to change themselves (specifically their views) so as to better accept the world. ${ }^{14}$

We can get a better understanding of the idea of redemptive insight or knowledge in Buddhism by looking at the concept of pañ $\tilde{a}$. Pañ $\tilde{a} \bar{a}$, insight, reason or understanding, leads to freedom. Pañña is better than any wealth (dhana) since by pañña one reaches perfection (vosāna), the venerable Rațhapāla explains to King Koravya in the Ratțhapāla Sutta of the Majjhimanikāya. Gautama dealt with an uncontrollable world not by trying to gain the power to actually modify it - not by becoming a cakravartin - but by trying to understand its essence, by awakening to the truth, by becoming a Buddha. He adopted a strategy which was the opposite of that of the men of the world like Kalabu and Ajātaśatru. His followers also gained a feeling of control through the sharing of his interpretation of existence and suffering. In the Mahālisutta the Buddha tells Mahāli about the highest and most excellent things for the sake of which the monks lead the religious life:

And then further Mahāli, a monk, freed from the intoxications by the destruction of the intoxications having, by himself, understood, having realised, having attained release of the mind (ceto-vimutti) and release by insight (paññ $\bar{a}$-vimutti) abides in the present existence. That, Mahāli, is a condition higher and 
more excellent for the sake of which the monks lead the religious life under me. ${ }^{15}$

In the Kassapasīhanādasutta the Buddha explains to Kassapa:

From the time, O Kassapa, when a Bhikkhu has cultivated the heart of love that knows no anger, that knows no illwill - from the time when, by the destruction of the intoxications he dwells in that emancipation of the mind (ceto-vimutti), that emancipation by insight ( paññ $\bar{a}$-vimutti), that is free from those intoxications, and that he, while yet in this world, has come to realise and know - from that time, O Kassapa, is it that the Bhikkhu is called a Samana, is called a Brahmana. ${ }^{16}$

Pañ $\tilde{a} \bar{a}$-vimutti is usually mentioned together with ceto-vimutti. Gombrich has shown that these two concepts originally referred to the same thing. ${ }^{17}$ Later scholastic Buddhist interpretation of these terms would explain them as different and see paññ $\bar{a}$ as the superior of the two. Insight became ever more important. This development was closely connected with the later scholastic view that one could gain enlightenment without meditation, something that was never envisaged by the Buddha himself, according to Gombrich. ${ }^{18}$ This does not mean that insight was unimportant to the Buddha. Release of the mind and release by insight were central to the Buddha's idea of salvation, although one might perhaps say that release of the mind is most fundamental because release by insight only describes a way to the goal.

\section{Conclusion}

I have tried to suggest an approach to religious motivation with examples from early Buddhist literature. The approach that I have chosen sees psychological incongruity, the discrepancy between an internal standard and an external stimulus, as a basic motivational factor leading the individual towards religious innovation or conversion. Two conceptualizations of psychological incongruity were used: the theory of cognitive dissonance and the concept of secondary control.

A number of objections could be made to the application of modern psychological constructs to early Buddhism. One of the sins committed in this chapter is summed up in one disquieting 
word: reductionism. The social scientific study of religion seeks to develop generalizations about religion that can be applied across cultures and time periods. It seeks concepts and measurements that have cross-cultural validity. In doing so it adopts a reductionist method. The objections that some scholars have to the application of social scientific theory to religion are often based on a fear of reducing the different manifestations of a religion to simpler factors and in this process losing the essence, the irreducible sacred core, of the religion. The discussion of reductionism and autonomy is complex, and scholars who are sympathetic to a particular religious tradition often find the questions raised vexing and choose to avoid them altogether. In a previous chapter I criticized determinism, especially the biological type, in the study of the conversion process.

Many years ago Penner and Yonan defined four areas of particular importance for a clarification of the scientific status and the research strategies of religious studies. These were the questions of definition, reduction, explanation and understanding. The authors argued that scholars disqualify themselves by running around the first hurdle in the study of religion, i.e. the question of definition, and by avoiding this problem they also keep away from the other three issues. Indeed, all four questions are closely inter-related and need to be confronted head on, although to hope for an easy solution is naive. Unfortunately, the term 'reduction' has become a booword employed by scholars who wish to avoid the more complex methodological issues in the study of religion, and this attitude is classically represented in theories that speak of religion as a sui generis phenomenon and insist on approaching the subject through the 'incredibly obscure operation of understanding', as Penner and Yonan called it. ${ }^{19}$ The fear of reduction and reductionism often builds on the misunderstanding that it is the phenomena themselves that are reduced rather than our theories about them. Reduction in any normal sense of the word is about reducing theories to simpler theories, and if scholars understand this and still insist that reduction has no place in the study of religion it must be because they see theories about religion as irreducible. This, however, simply amounts to an anti-scientific stance that should have no place in academia.

In the end, what we want to know is whether human beings have so much in common despite obvious cultural differences that it is possible to explain their feelings and their behaviour by theories made in a particular culture, or whether human beings, as relativists 
assert, become human solely through enculturation and have nothing in common on which to base comparison or cross-cultural analysis. A psychological theory that seeks to explain some aspect of religion, independent of time and place, must reduce particular observations of feelings, ideas and behaviour, which are necessarily culture-specific, to observations that are independent of the culture in which the observations were made. Such a theory presupposes a universal human nature, and some scholars would say that no such thing exists. The discussion of cultural relativism is a large topic in anthropology but has never gained the same prominence in the field of religious studies, and since a serious exposition here would bring us too far astray, I will simply agree with Argyle and Beit-Hallahmi that just as religious beliefs display similarities across cultures so do the psychological mechanisms involved in belief, ritual and myth. ${ }^{20}$ 



\section{RELIGIOUS MOTIVATION AND THE ROLE OF FEAR}

May the fearful become fearless and those oppressed by grief find joy. May those who are anxious be rid of their anxiety and feel secure.

Śāntideva ${ }^{1}$

The link between fear and religious motivation has been a valid subject of investigation for scholars in modern anthropology and psychology, and writers in search of the psychological origins of religion have taken a special interest in this subject. ${ }^{2}$ In the Christian world these links have been highlighted by Kierkegaard among others. Fear often has a religious role in India too. However, except for a recent semi-scholarly essay on fear and Buddhism, nothing has been written on the subject of fear in Indian religions. ${ }^{3}$ In this chapter I wish to illuminate certain aspects of fear in the religious thought of the Indian sub-continent and Buddhism in particular. It will become clear, I hope, that fear has an important role to play in religious motivation in Buddhism.

Let me make a few reservations before I continue. The point of departure for the discussion of fear in this chapter is a specific puzzle in Buddhist literature, and Indian literature in general, that deals with the life of the religious renouncer and the way towards the adoption of this life. I will define the problem in more detail over the following pages. Fear is a vast subject in Indian literature, and a number of different approaches could be adopted to the topic and a number of links explored. For instance, it might be fruitful to look at the innumerable associations between fear and sexual desire, between the horrible and the erotic. ${ }^{4}$ Perhaps the most interesting link would be the one leading to Indian drama. The Nātyás àstra of Bharata Muni has terrifying (bhayānaka) as one of the eight 
tastes or sentiments (rasa) that a drama can apply in order to move its public. To the terrifying sentiment belongs the emotion of fear (bhaya). In the famous chapter on sentiments, the Rasādhyāya, Bharata Muni explains:

Now (the rasa) called bhayānaka has fear as its permanent emotion. It arises from such vibhāvas as ghastly noises, seeing supernatural beings (ghosts), fear and panic due to the (cries) of owls (or the howling of) jackals, going to an empty house or to a forest, hearing about, speaking about, or seeing the imprisonment or murder of one's relatives. It should be acted out by such actions as trembling of the hands and feet, darting motions of the eyes, the hair standing on end, changing facial color (i.e. going white with fear) or stuttering. ${ }^{5}$

The Nätyásāstra's theory of sentiment has had a substantial impact on Indian thought on emotions outside literary theory and drama, too, from at least the third or fourth century $\mathrm{AD}$, and it is not unlikely that monks and scholars who discussed the role of fear in a religious context have had knowledge of Bharata Muni and other theorists' treatment of the terrifying sentiment and its corollary, fear. However, the possible links between the dramaturgical and the religious ideas of fear is an example of one fascinating line of enquiry that I must leave out of this chapter. I am going to restrict my discussion to one area, namely the double role of fear in some of the textual religious traditions of India. As will soon become clear, the role of fear in Indian religion, and especially in Buddhism, seems to be somewhat paradoxical and this is the point of departure for this chapter. Before we go into this in detail, however, I will take a brief look at fear in its more familiar forms, the little fears of the everyday life of renouncer and householder, what may be called trivial fears.

\section{The trivial fears of monks and householders}

Fear and the desire to escape it is a theme in Buddhist Pāli literature. In its trivial sense fear is a factor of both the individual and social life of the Buddhist monk. Fear is one side of the multifaceted emotional complex of every human being, and freedom from fear is an aspect of the general calming of the mind that is the goal of 
Buddhist meditation. The overcoming of fear often becomes a meditative practice. In the chapter on pleasure, Piyavagga, of the Dhammapada several verses explain the interconnection between the pleasant and painful feelings. What is pleasurable (piya) and also affection (pema), fondness (rati), desire (kāma) and craving (tanh $\bar{a})$ all lead to grief (soka) and fear (bhaya). ${ }^{6}$ Typically, when one is free from the pleasurable feelings, one will also be free from grief and fear. Overcoming fear is part of the monk's way to detachment from worldly matters. The Dhajagga Sutta says that when the monk recollects (anussarati, sarati) the Buddha, the Dhamma and the Samgha they will experience no fear (bhaya), paralysis (chambhitatta) or bristling of body hair in excitement (lomahamsa). ${ }^{7}$

In the Bhayabherava Sutta of the Majjhima Nikāya the Buddha speaks about the overcoming of the fears of dark and remote places as an exercise of the mind. He explains how he approached horrifying places like orchard shrines, woodland shrines and tree shrines on auspicious nights and dwelt there in order to encounter fear:

And while I dwelt there, a wild animal would come up to me, or a peacock would knock off a branch, or the wind would rustle the leaves. I thought 'What now if this is the fear and dread (bhayabherava) coming?' I thought: 'Why do I dwell always expecting fear and dread? What if I subdue (pativineti) that fear and dread while keeping the same posture that I am in when it comes upon me?' While I walked, the fear and dread came upon me; I neither stood nor sat nor lay down till I had subdued that fear and dread. While I stood, the fear and dread came upon me; I neither walked nor sat nor lay down till I had subdued that fear and dread ... ${ }^{8}$

There are several different enumerations of things that cause fear in the Pāli texts, and many of these are negligible as subjects of scholarly investigation. For instance, the Sutta Nipāta says that there are five causes of fear that can disturb the monk, namely gadflies (damsa), moths or mosquitoes (adhipāta), creeping animals (sirimsapa), contact with humans (manussaphassa) and four-legged beasts (catuppada). ${ }^{9}$ In this context fear is discussed as something that must be calmed along with other affects. The Buddha explains to Sāriputta the mind-set that should be cultivated by the monk 
who settles down far away by the root of a tree, in a cemetery or in a mountain cave. The Sutta Nipāta, then, just like the Bhayabherava Sutta above, is not talking about an existential fear that makes people renounce the world, but rather minor fears that must be calmed by the monk who is engaged in meditation.

Fear in its trivial sense is also a force that controls social life. Typically, four types of fear are thought to guide the monk in a social setting. The fear of self-reproach (attānuvāda bhaya), fear of reproach by others (parānu bhaya), fear of punishment (danda bhaya) and fear of lower worlds (duggati bhaya) all make the monk avoid unwise actions and function as a social being. ${ }^{10}$ The fear of reproach by the laity, for instance, seems to have been an important force in the shaping of the Buddhist Samgha.

Fear can be destructive and paralysing. The trivial fear of the common man is not only unprofitable but directly harmful from the perspective of the renouncer. Fear is one of the four motives (thāna) by which people do evil deeds, the Buddha tells Sigāla. ${ }^{11}$ Fear as motivation in the everyday life of the householder is destructive. The gift to the Samgha given out of fear (bhayadāna) is impure (avisuddha) says the Mahāyāna literature on giving. ${ }^{12}$ Lamotte suggests that this is because impure attachment or interest of any kind makes the gift impure while the only pure (visuddha) gift is the one given with complete detachment. However, as I have tried to show elsewhere, there has been a tendency to make giving a more pragmatic activity in which all modes of donating produce merit. ${ }^{13}$

While fear should not be a form of motivation in the everyday life of the monk or the householder fear is at the core of religious motivation. Without fear gods and men do not realize the need for religious exertion. Thus, one must discard the wrong fear and embrace the right fear. Ling speaks of the fundamental difference between, on the one hand, dangers that it is possible to escape, like armies, mad elephants, yakkhas, etc. and, on the other hand, the great danger of death, personified in Māra, which is ultimately inescapable. ${ }^{14}$ It is the realization of such great and inescapable dangers - death, birth, old age - that is the basis of the non-trivial fear that is the subject of this chapter. One must choose the right fear. In the words of the Dhammapada: 'They who fear when they ought not to fear and do not fear when they ought to fear, such men, following false doctrines, enter the evil path. ${ }^{15}$ What makes one experience of fear good and another bad? 


\section{The paradox of fear}

If we start looking a little closer at the role of fear in Indian religious thought it becomes apparent that the subject has a fundamental doubleness to it. On the one hand, fear is the natural state of samsāric existence. The basic facts of life - such as birth, sickness, ageing and death - cause fear in living beings. Conversely, freedom from fear is an important aspect of complete religious realization. On the other hand, fear is a necessary state of mind in the striving to escape samsāric existence and achieve freedom. Fear should be cultivated as the basic motivating factor in the religious life. Thus, fear is both a negative thing from which beings should try to escape through religious exertion and a positive thing without which the very same exertion is impossible. In other words, if one starts to look into the ideas about fear in Buddhism, and Indian soteriologies in general, it soon becomes clear that it is a complex subject, and the fact that it has been neglected by indologists and historians of religion becomes difficult to comprehend.

The double function of fear is perhaps most apparent in Pāli Buddhism and the textual basis of this tradition will provide the most important examples in this chapter. The Buddha leads his followers from the fear of samsāric existence towards freedom from fear. He is the Dispeller of anguish, terror and fear (ubbegam uttāsam bhayam apanuditar). ${ }^{16} \mathrm{He}$ is the Bestower of fearlessness (abhayada). ${ }^{17}$ But at the same time his function is to create dread in gods and men. When a Buddha arises in the world and teaches the Dhamma the gods experience fear, agitation and trembling. ${ }^{18}$ In the Perfection of Wisdom literature (prajñāpāramitāa) too it is a common assertion that the teaching of emptiness ('sunyata) is too terrifying to be taught to people who have not reached a certain stage in spiritual development. ${ }^{19}$ What is the difference between the fear that the Buddha creates and the fear that he destroys?

The same paradox can be found in Jainism. According to several medieval Jain authors, freedom from fear (nih́sanka) is a primary part (arga) of right view or belief (samyaktva). For instance, Cāmuṇararāya lists seven types of fear: fear of this world (iha-loka), fear of the next world (para-loka), fear of sickness (vyädhi), fear of death (marana), fear of being without protection (agupti), fear of being without defence (atrāna) and fear of something unexpected (akasmika).$^{20}$ These kinds of trivial everyday fears are detrimental to the religious life and must be destroyed. Jaini has listed fear (bhaya) as one of nine 'everyday passion-tinged experiences', 
which will gradually disappear as an individual becomes more spiritually advanced. ${ }^{21}$ Thus, fear is a symptom of low spiritual attainment in Jainism too. At the same time it is clear that a certain kind of fear is a prerequisite for success in the religious life. In Jainism samvega has more or less the same function as in the Buddhist examples below. In works by some of the medieval Jain authors samvega has been codified as part of the lists of right view or right belief - samyaktva or samyagdrști. Pūjyapāda, the Digambara commentator of the Tattvārthasütra - who lived perhaps in the fifth century AD or slightly later - defined samvega as the ever-present fear of transmigraton, whereas the greatest of the Śvetāmbara authors, Hemacandra, defined samvega as 'the desire for moksa arising from the realization that the pleasures of gods and men are, in the last resort, unsatisfying. ${ }^{22}$ For the Jain authors samvega is the unease or fear that arises from the basic facts of life in samsāra. Thus, both fear and freedom from fear have been listed as right views for the Jains.

In the following I will look more closely at the two roles of fear in Indian religion and especially in Buddhism. First, I will look at freedom from fear as the goal of religious striving or as a characteristic feature of salvation; second, I will look at fear as a means to religious achievement or as the basis for religious motivation. Finally, I will try to put the double role of fear in the context of the religious history of India. I am going to argue that in Buddhism, from which I take most of my examples and in which the doubleness is most clearly expressed, fear was part of the arsenal of the great missionary movement that spread Buddhism throughout the subcontinent and to Sri Lanka from around the middle of the third century BC It is likely that Buddhist missionaries used the induction of fear as a technique to make people more receptive to the new movement and its teaching and, conversely, the dispelling of fear was an effective way of binding fresh converts to the community. ${ }^{23}$ As I will try to show, traces of such an active use of fear can be found in the Pâli texts. I believe the widely accepted view that Buddhism spread simply because of the exemplary manners of its proponents and the rational and pleasing nature of its teaching is naive. 


\section{Freedom from fear as the aim of religious striving}

All men fear punishment and death, according to the Buddha, but the Arahant has passed beyond all fear (sabbabhayam atikkanto). This is one of the paradoxes with which King Milinda presents the Venerable Nāgasena in the Questions of King Milinda. But this is not really a paradox, Nāgasena explains, because the Arahant is an exception to the general statement that all men fear death. ${ }^{24}$ For the Arahant all causes of fear have been cut off. Freedom from fear is a constituent of Arahantship. The Arahant is free from fear and terror (pahinabhayabherava). ${ }^{25}$ As we are told in the verse of Sambula Kaccāna in the Theragāthā the monk had no fear (bhaya) although he stayed in a horrible cave (bherave bile) and in spite of a rainstorm roaring outside. ${ }^{26}$ The commentary explains that although all other creatures cry out in fear at the thunder and lightning the thera had no fear inside his horrible den because he had achieved insight. In other words he is on the way to Arahantship.

The Buddha himself had many similar experiences with dreadful things. Typically, Māra, the evil one, approaches the Buddha in order to frighten him and make him stray from his path. On one occasion, for instance, Māra approaches the Lord in the form of an enormous cobra in order to cause fear (bhaya), paralysis (chambhitatta) and make his body hair bristle with excitement (lomahamsa). The Buddha sees through the plan of his evil adversary and he explains that all living beings may try to frighten him and still they will never succeed. ${ }^{27}$ Not only the Buddha Gotama had to struggle with fear in order to achieve perfection. This is a common theme in the life of previous Buddhis as well. In the Buddhavamsa it is said that Buddha Kassapa, the twenty-fourth Buddha, created the flower of fearlessness (abhaya puppha) ${ }^{28}$ The Madhurathavilāsin̄ explains in its commentary to this verse that the flower is the eightfold way leading to the city of no fear (abhayapura) which, of course, is the equivalent of Nibbāna. ${ }^{29} \mathrm{It}$ was fear and dread at the sight of old age, sickness and death that made the Buddha Vipassi forsake the world, as I will return to shortly. One of the characteristics of a Buddha according to later Buddhist literature both of the Mahāyāna and the Hīnayāna sects is the four assurances (vaisāradya). According to the Abhidharmakośabhasyam these assurances are the assurance that he has attained supreme comprehension with respect to all dharmas, the assurance 
that he has knowledge of the destruction of the defilements, the assurance that he can fully explain the dharmas and the assurance that he can explain the path leading to definitive deliverance. ${ }^{30}$ These assurances are or entail absence from fear.

The word vais̄a radya signifies 'absence of fear' (nirbhayatā). By reason of the fact that he knows that he has understood all the dharmas, destroyed all the defilements, etc., the Buddha is free from fear in the assemblies. ${ }^{31}$

The way towards freedom from fear is a central concept in the idea of salvation in Pāli Buddhism. Buddhaghosa concludes his exposition of the four noble truths by giving seven different similes of the truth of suffering, its origin, its cessation and the path to its cessation. One of these similes is based on fear. According to Buddhaghosa, the four noble truths can be understood as fear (bhaya), the origin of fear (bhayamūla), the freedom from fear (nibbhaya) and the means to attain this (tadadhigamupaya). ${ }^{32}$ The expressions released from fear (bhaya pamutta) and set free in fearlessness (abhaye vimutta) are descriptions of the nibbānic state..$^{33}$ Nibbāna is freedom from fear.

The idea that freedom from fear is an aspect of the highest religious or spiritual attainment is certainly older than Buddhaghosa and, indeed, older than Buddhism. According to the Chândogya Upanișad, gods and men become free from fear and immortal by uttering the sound Om. ${ }^{34}$ Fear is one of the characteristics of the self (ätman) according to the Chāndogya and Brhadāranyaka Upanisads. ${ }^{35}$ The self is immortal, free from fear, it is Brahman, says the Chāndogya Upanișad 8.3.4. ${ }^{36}$ Reaching the state of no fear implies realizing the self. In the Prásna Upanișad freedom from fear (abhaya) is one of the characteristics of the highest stage which only can be reached by meditation on the syllable Om. ${ }^{37} \mathrm{In}$ the Katha Upanisad freedom from fear is found in heaven. Here one has no fear of death or old age, Naciketas explains to Yama. ${ }^{38}$ The Taittirìy U Uanișad also makes it clear that freedom from fear is a characteristic feature of the perfected state: 'For when a man finds within that invisible, incorporeal (anätmya), indistinct, and supportless essence, the fearless stage on which to rest, then he becomes free from fear. When, on the other hand, a man creates a hollow or a fissure within it, then he experiences fear. ${ }^{39}$

In commenting on this verse of the Taittirīya Upanișad, Śanikara 
picked up the topic of fear and offered an explication of the nature of fear emphasizing the doctrine of non-duality. One attains fearlessness (abhaya) by recourse to the true essence (sadvastu), Śankara said. One does not attain the cessation of fear through recourse to what is not the true essence. In other words, only by recourse to Brahman does one attain freedom from fear. Fear is produced by someone else, Śankara continued. It is not the case that one's fear is produced by oneself. When one becomes steadfast in one's true being (svarūpapratiștha), then one neither sees, hears nor discerns any more. When one sees no other and does not create a splitting (bheda) within the self one has reached freedom from fear. Then there is nothing outside the self to create fear in the self. It is the idea of duality caused by ignorance (avidy $\bar{a}$ ) that is the basis of fear, according to Śankara and, as we saw above, the Taittiriya Upanișad naturally lends itself to this interpretation by stressing that the creation of a fissure (dara) in the self is the cause of fear. ${ }^{40}$

The Brhadāranyaka Upanisads, too, suggests that the state of fearlessness is reached when one realizes that there is no other, that there is nothing apart from the self. The first being became afraid, it says, and therefore one becomes afraid when one is alone: 'Then he thought to himself: "Of what should I be afraid, when there is no one but me?" So his fear left him, for what was he going to be afraid of? One is, after all, afraid of another. ${ }^{41}$ Verily, Ś ankara said in his commentary to this verse, fear arises from a second (dvitīya), from another object (vastvantara). This second, the other object, appears only through ignorance (avidy $\bar{a}) .{ }^{42}$ When one attains the realization that the self is alone, that everything else is caused by ignorance, there is nothing to cause fear any more. One has reached salvation.

Thus, the idea that freedom from fear is an important aspect of the highest spiritual attainment is present in the Upanișads and in the Vedānta as it is represented by Śankara. When we look at freedom from fear as a characteristic of the goal of religious striving there are clear parallels in Buddhism, Jainism and Hindu soteriology. When one has no idea of another any more and when one does not create a splitting or fissure within the self then there is nothing to be afraid of, according to the Upanișads referred to above. It is the overcoming of duality caused by illusion, according to the Advaita interpretation.

Not surprisingly perhaps, there are parallels to this explanation 
of the origins of fear in Madhyamaka Buddhism. ${ }^{43}$ The spiritual and fervent poetry of the scholar monk sanntideva - who probably flourished in the eighth century AD and is associated with the great Buddhist university at Nālandā - is an interesting source for the understanding of the role of fear in this tradition. Indeed, large parts of his Bodhicaryāvatāra can be seen as attempts to induce fear of samsāra and a motivation to escape its afflictions. The horrors of samsāric existence are graphically described and, most importantly, a sense of great urgency for the religious life is conveyed. How can you lead a normal life when Yama, the god of death, is sizing you up at every turn, when you have entered the mouth of death, when you hear the hellish bellowings and behold the grief-stricken faces of relatives? Quaking from terror, your body caked in excrement what will you do $?^{44}$ Of course, says Śāntideva, you must enter the path of the bodhisattva and exert yourself to achieve perfection.

The Prāsanigika tradition of the Madhyamaka, of which Saantideva was a representative, holds that nothing exists apart from the mind. One possible meaning of dependent origination (pratītyasamutpāda) for the Prāsangikas is origination in dependence on the designating mind. ${ }^{45}$ But if fearful objects do not really exist from where does the fear arise? In the answer to this question Śantideva reveals a certain affinity with the Vedāntic ideas of the origination of fear:

So too tigers, lions, elephants, bears, serpents, and all malign beings, and all the guards of hell, ogresses, demons, / All these are bound through the binding of a single mind, and through the taming of a single mind, all are tamed, / Since all fears and incomparable sufferings arise from the mind alone. So it was taught by the Teacher of Reality. / ... Every single thing arises from the evil mind, sang the Sage. So there is nothing dangerous in the three worlds other than the mind. ${ }^{46}$

All fears arise from the mind and when the mind is controlled fear will cease. Sanntideva seems to explain the origin of fear from the existence of the mind. Later, however, he summarizes an opponent's argument for the existence of a self which says that fear demonstrates the existence of an ' $\mathrm{I}$ ' ${ }^{47} \mathrm{In}$ other words, he refutes the induction of an 'I' from the existence of fear. Is there a weakness in the reasoning of Santideva on this point? Also in the Śikṣa 
Samuccaya, Śāntideva's other great work, it is clear that fear originates in wrong ideas about identity. 'Fear arises from the holding on to the self [ätmagrāha].' it says. ${ }^{48}$ The bodhisattva who lives in forest seclusion must get rid of the sense of self, achieve detachment and realize that there is nothing to be afraid of apart from that which the mind creates.

In Pāli Buddhism, too, fear ultimately arises from the mind's involvement with the outside world. There are fundamental differences concerning the reality of the world and the self in Vedānta, Madhyamaka and Pāli Buddhism ${ }^{49}$ However, in all these philosophies it is the interaction of the mind with external objects that causes fear. Fear springs from acquaintance or intimacy (santhavāto bhayam jātam), according to the Sutta Nipāta. ${ }^{50}$ The Pâli texts that deal with meditation all stress the importance of detachment from the world and from one's own sense experiences.

The idea of detachment is also part of some of the most important symbols and metaphors of Buddhahood and Arahantship. The lotus is often used as a symbol because it grows in muddy water without getting tainted by its dirty surroundings. Animals like the elephant and the rhinoceros also symbolize loneliness and detachment from the world. The Buddha or the Arahant is often called a lion. This is because the lion symbolizes strength and royal power, but also, I think, because the lion lives alone, away from the other animals it is aloof, separate and completely detached. As I will return to consider shortly, the Buddha, just like the lion, causes fear but is never subject to fear himself. In the Sutta Nipāta there is a story about the Brahimn Sela - and 300 followers - who wishes to go and see the Buddha. As they set out Sela tells his companions that they must thread carefully on their way to the Lord because lords are hard to approach like lions that roam alone (durāsadā hi te bhagavanto sìh $\bar{a}$ va ekacarā $).{ }^{51}$ The Buddha and the Arahants are unapproachable lions. They are aloof, separate, with minds drawn away from the disturbing sights of the world. The Brahmin Sela tells the Buddha that he is an unattached lion free from fear and terror (sīho si anupādāno pahīnabhayabheravo). ${ }^{52}$ Complete detachment is a prerequisite for freedom from fear.

These brief remarks suffice, I think, to conclude that there are clear parallels across the Indian religious traditions concerning freedom from fear as an important aspect of religious realization. There are also indications that fear is a source of motivation and a prerequisite for religious striving in a range of Indian soteriological 
traditions. Patañjali's Yogasūtra 1.21 indicates that samvega is a feeling that puts extra energy and commitment into the meditation practice. Samvega is here a quality that makes samādhi easier to attain. ${ }^{53}$ However, neither Patañjali nor the commentators discuss the nature of samvega and it is therefore difficult to judge how close it is to the concept in Buddhism or Jainism. I will concentrate on Buddhist material in the following exposition of fear as a means to religious achievement.

\section{Fear as religious motivation}

I have discussed earlier how birth, ageing, sickness and death are considered to be causes of samvega. According to the Buddha biographies, the young Gotama was motivated by the same kinds of experiences. On three pleasure excursions outside the palace he saw an old man, a sick man and a corpse. As the Thüpavamsa sums up the prelude to the great renunciation, the prince was overcome by fear (samvegajāta)..$^{54}$

The term samvega occurs several times in the Pâli canon. In the Sangìti Suttanta the Venerable Sāriputta lists samvvega, the agitation over agitating conditions (samvejaniyesu thānesu), as a point in his summary of the Buddhist doctrine. ${ }^{55}$ In the Forest Suttas of the Samyutta Nikāya monks who stay in forests become neglectful of their religious discipline in different ways. One is indulging in wrong and evil thoughts during their siesta, another is falling asleep, while some have excessive contact with the laity. As a consequence, the devas of the forests wish to agitate them (samvejetukāma $\bar{a}$ ) out of compassion and address the monks with verses. The idea is that when the monks are properly agitated, when they experience a sufficient amount of samvega, their religious discipline will improve. ${ }^{56}$ In the Sayings on the Limbs of Wisdom in the Samyutta Nikaya, samvega is one of the results on meditating on the idea of a skeleton. ${ }^{57}$ Other objects of meditation, which would have the same effect of creating fear and disgust with transient things like the human body, are corpses in different stages of decay.

The same list is found in the Ariguttara Nikāya, in which we are told that the idea of a skeleton (atthikasañña), the idea of a wormeaten corpse (pulavakasañ $\tilde{a}$ ), the idea of a discoloured or bluish corpse (vin̄ilasaññā), the idea of a festering corpse (vipubbakasañ $\tilde{a} \bar{a}),{ }^{58}$ the idea of a corpse full of holes (vicchiddakasañña), and 
the idea of a swollen corpse (uddhumātasañña) are all signs of concentration (samādhinimitta). ${ }^{59}$ This kind of meditation is reflection on impurity (asubhakammațthāna). In the Abhidamma the ten impurities - corpses in different stages of decay - are part of a compendium of meditation subjects..$^{60}$ Those who night and day follow the teaching (sāsana) of the Buddha always have the realization of impurity (asubhasaññin), says the Itivuttaka ${ }^{61}$ The Itivuttaka devotes one sutta to samvega. ${ }^{62}$ The monk who is possessed with two things lives at ease and is disposed towards the destruction of the a asavas - the intoxications of the mind which traps man in samsāric existence - and is thus on his way to Arahantship. The two things are samvega and exertion (padhāna), which comes as the result of samvega.

We saw above that the Buddha is sometimes thought of as a lion in his detachment from the affairs of the world and the lion becomes an important metaphor, too, in the ideas of the induction of religious fear. An interesting explication of the function of fear in Pāli Buddhism is found in the simile of the lion. ${ }^{63}$ Here the role of the Buddha in the world of gods and men is compared to the role of the lion in the world of animals. When the lion roars all other animals experience fear, agitation and trembling (bhayam samvegam santāsam āpajjanti). They creep into their holes, jump back into the water, run off into the forest or fly up in the air. The king's elephants break their bonds, void their excrements and run to and fro. In the same way, when a Buddha arises in the world and teaches the Dhamma the gods experience fear, agitation and trembling. ${ }^{64}$ They realize that they are impermanent, unstable, not to last and imprisoned in a person (mayam hi kira bho aniccā addhuvā asassatā sakkāyapariyāpannā $t i$ ). In other words, they are subject to the vicissitudes of samsāra just like other creatures. The function of the Buddha in the simile of the lion is to create fear through his teaching. The content of the Dhamma is intended to evoke fear in those who listen, and when this fear is effectively translated into religious motivation one will strive to attain Nirvāna.

Samvega occurs with the same meaning of an emotional perturbation motivating the religious life in the Prātimokșasūtra of the Sarvāstivādins. It is part of the pessimistic introductory description of the condition of the world. Everything is in rapid decay, soon men will be like beasts, and the importance of the religious life is growing correspondingly. The monk should cultivate 
his affliction and open his eyes for the miseries of the world. Samvega is a desired mental state, which will make the monks listen attentively to the teaching of the Buddha. ${ }^{65}$

Buddhaghosa enumerates eight causes of samvega, the attha samvegavatthu, which should be contemplated by the monk when the mind needs to be encouraged on the path of religion. These are birth (jāti), ageing (jarā), sickness (vyādhi), death (marana), suffering of loss (apāyadukkha), suffering of past and future rooted in the round of rebirth (atite vattamūlaka dukkha), and the suffering of the present rooted in the search for nutriment (pacuppanne $\bar{a}$ ārapariyețthimūlaka dukkha) ${ }^{66}$ Later in the Visuddhimagga Buddhaghosa spells out the connection between religious motivation and fear in more detail. ${ }^{67}$ First, he looks at knowledge of appearance as fear (bhayatupațhānañāna). To the person who has this knowledge the formations (sankhāra) and their inevitable cessation and dissolution appear, in the past, present and future, as terrible beasts, lions, tigers, yakkhas, rakkhasas, etc. Then follows knowledge of contemplation of danger (ädinnavānupassanānāana) whereby the three types of becoming (bhava), the four great elements (mahābhüta), the five constituent elements (khandha), the six inner and outer ayyatana, i.e. the sense organs and their objects, the seven types of consciousness (viññanna), etc. appear as terrible dangers such as snakes, murderers, disease, etc. Then, as the result of seeing everything as great dangers, comes knowledge of contemplation of dispassion (nibbidānupassanāñāna). Finally, there is the knowledge of the desire for deliverance (muñcitukamyatāñāna).

According to Buddhaghosa, then, when the monk meditates on fear he comes to see all formations and all becoming as danger. All forms that life may take are dangers because everything is necessarily subject to dissolution and cessation. From seeing all formations as danger he grows dispassionate. From the dispassion and detachment arises the desire for deliverance. It is a commonplace in the Pāli literature that dispassion and detachment is a prerequisite for - or even a constituent of - religious realization. Virāga is often used to achieve nibbāna. But in Buddhaghosa's exposition of fear dispassion presupposes fear and is a stage in between fear and the desire for freedom. In fact, says Buddhaghosa, tradition has it that the three kinds of knowledge leading up to the knowledge of the desire for deliverance are essentially the same thing. ${ }^{68}$ The appearance as fear comprises contemplation of danger 
and contemplation as dispassion. What we are left with, then, is a complex of fear and contemplation of danger leading up to the desire for deliverance or nibbāna. Religious motivation is in fact a result of fear in Buddhaghosa's exposition.

Mahāyāna Buddhism also has the idea that fear is an essential motivating factor on the way to embracing the path of the bodhisattva. Śāntideva's Bodhicaryāvatāra is apparently meant to induce such motivation: 'Realizing that you are like a captive fish, how right it is for you to be afraid right now' and 'Out of the fear of suffering, and while meditating on the praises, one should create desire. ${ }^{69}$ In meditating on the Buddhas and bodisattvas one should remain possessed of fear. ${ }^{70}$ Suffering and fear are indeed constructive and positive things for Sanntideva as long as they lead to the adoption of the religious life:

The virtue of suffering has no rival, since, from the shock it causes, intoxication falls away and there arises compassion for those in cyclic existence, fear of evil, and a longing for the Conqueror. $^{71}$

The way from fear to the adoption of the life in religious exertion is described in a vivid and personal manner by the Madhyamaka scholar. Someone who is taken away to have a limb cut off is seized with fear and sees the world in a completely different way. But even this is nothing compared with the fear experienced by the one who realizes the horrors of samsāric existence. It is a tremendous fear that transforms his life:

With cowering glances I search the four directions for deliverance. What saint will deliver me from this great fear? / Right now I go for refuge to the mighty Protectors of the world, who have undertaken the care of the world, the Conquerors who remove all fear. / Trembling with fear I give myself to Samantabhadra, and again freely I give myself to Mañjughoșa. / Terrified I cry out in anguish to the Protector Avalokita whose conduct overflows with compassion. I have done evil. May he protect me. / I have transgressed your command. Now, at seeing the danger, terrified, I go to you for refuge. Destroy the danger, quickly! ${ }^{72}$

If we return to the Śikṣa Samuccaya we will find more material 
that shows how fear was thought to be a determining motivating factor for the adoption of the religious life. Fear is a prominent theme in the praise of the life of seclusion in the forest. The bodhisattva who has left the world and dwells in the forest observes that the life of seclusion alone does not make anybody an ascetic. Indeed, there are a number of beings who live in the forest - such as animals, robbers, candāalas - and are nevertheless devoid of ascetic qualities (śramanaguna). So what is the difference between the bodhisattva and these other forest-dwellers? It is the bodhisattva's motivation. He must ask himself: To what end have I come into the forest? The answer is fear (bhayabhīta):

It was fear that brought me to the forest. Fear of what? The fear of worldly society, the fear of company; the fear of passion, hatred, delusion; the fear of pride, intoxication, hypocrisy, pain; the fear of praise, envy, and jealousy; the fear of form, sound, smell, taste, touch; I was afraid of the ideas of individuality and possession, afraid of arrogance and of doubt, afraid of the Māra of the elements of being, the Māra of sin, the Māra of death, the Māra of the gods; ${ }^{73}$

Sañntideva's list continues. The aspiring bodhisattva was frightened by different kinds of ideas and feelings of worldly life as well as the prospect of rebirth in hell or other low forms of existence. He concludes: 'It was the fear of all such terrible things that led me to go into the forest.' 74

The forest itself, however, is full of fear and dangers, and without the right attitude to these fears no advancement is possible for the monk dwelling in the wilderness. A clue to understanding the role of fear in Buddhism is the determination and skill that is needed to take advantage of it. For the common man fear is destructive simply because he is not able to employ it in a constructive way. For the advanced monk the opposite is the case. A good example of how fear is thought of as something which must be taken control of and channelled correctly is found in the summary of the five fears. There are future or potential fears (anägatabhaya), which when contemplated upon (sampassati) should make the monk live to attain the unattained. ${ }^{75}$ These are about the dangers that may cause 
the monk's death in the forest. Animals, for instance, are a prominent threat to his health:

Take the case of a monk, forest-gone, who reflects thus: I am now quite alone in the forest; and living here alone, a snake may bite me, a scorpion may bite me, or a centipede may bite me, and cause my death; and that would be a hindrance to me. Behold now, I will put forth energy to attain the unattained, to master the unmastered, to realize the unrealized. ${ }^{76}$

The list continues with all the different fears of forest life that may lead to the death of the monk. Interestingly, the fears include not only the threat from animals - apart from poisonous creatures, there are lions, tiger, hyenas, etc. - but also the fear of social breakdown due to famine and bad crops or the movements of people threatened by robbers. ${ }^{77}$ This reveals how even the forest-dwelling monk in the last instance is dependent on the world for his existence and religious practice. The point of all these different fears, however, is to use them in a constructive way. All the fears that are not yet realized but which the monk can behold in the future (anägatabhaya) must make the monk exert himself (viriyam a arabhati) to attain the unattained..$^{78}$ The expectation of horrors should cause a motivating fear that sets the mind firmly on the right path.

It is clear, then, that in Buddhist literature, both in the Hīnayāna and the Mahāyāna, fear is seen as an important means to religious achievement. However, as far as I have been able to determine, this is not the case in other Indian soteriologies, except, to some extent, in Jainism. Of course, there are a great number of traditions that I have not been able to look at in this brief survey and a more thorough examination of the role of fear in different branches of Hinduism may prove me wrong. However, if we accept for now the assumption that freedom from fear as the goal of the religious life is a general idea in Indian religions, whereas fear as an essential means on the way towards the goal is more or less peculiar to Buddhism, then we may want to ask why this is the case. Why was Buddhism alone in developing the idea of fear as a primary incentive to religious striving? To answer this I think we need to look at the ideas of mission in early Buddhism and the role of fear in missionary activity. 


\section{The induction of fear: an alternative view of Buddhist missionary activity}

I think it is clear from the discussion above that fear is an important topic in any discussion of religious motivation in Buddhism. From the literature I have looked at in this chapter it appears that freedom from fear is an aim of religious striving in different Indian soteriologies, whereas the idea of fear as a means to religious striving -fear as motivation - is found first of all in early Buddhism and, perhaps to a lesser extent, in Jainism. How did fear come to have this position in Buddhism? We may find a clue to answering this question by looking again at the conversion stories in the early Buddhist literature. Gombrich has pointed out that although the term 'skill in means' (upāyakauśsalya) is of later origin, the skill of adapting the message to the audience is of enormous importance in the Pāli canon. ${ }^{79}$ MacQueen has shown that one of the major themes of the Srāmanyaphalasütra is the Buddha's skill as a teacher. ${ }^{80}$ Having quoted passages from the Upāli Sütra in which the householder Upāli, a lay supporter of the Jains, is converted by the Buddha to the frustration of Nirgrantha Jñātiputra, MacQueen says:

So the Buddha was accused of knowing an enticing device (or, knowing conversion magic: āvattanim māyam jānāti). Whether he knew such or not, there is no doubt but that he must have been a highly skilled teacher. ${ }^{81}$

In the Śramanyaphalasūtra, the Buddha employs his skill in means in converting Ajātaśatru and the Buddhist literature gives many other examples of the Buddha's conversion magic. As in the case of the Jaina lay supporter in the Upāli Sütra, the missionary activity of the Buddha often takes place at the expense of other sects and a sense of contest is often reflected in such passages. Fear is an essential part of some of the paradigmatic conversion stories in this literature. As we have seen earlier, the biography of the Buddha himself is the prime example, but fear is also a prominent factor in the conversion stories of other people. This makes it natural to ask the question whether the emphasis on fear could have something to do with the missionary stance of Buddhism.

In one of the most outspoken expressions of the missionary zeal of the early Buddhists in the Pāli literature it is evident that fear is 
used as a means to convert new people to the growing movement of renouncers. In Chapter 2 I looked at the Mahävagga of the Vinaya Pitaka I.15-20, in which the Buddha tries to win over a group of matted hair ascetics, jatilas, to his movement. The Buddha performs many wonders in order to show that he is of greater perfection than his competitors. However, in the Buddha's competition with the jatilas his magical powers have little effect. The leader of the matted hair ascetics believes himself to be of greater power and of greater religious perfection than the Buddha and has no wish to give up his current practices in order to join the Buddhists. When every attempt has been made to convert the ascetics the Buddha finally resorts to his ultimate weapon, namely his ability to induce fear and unease. The Buddha induces samvega in the ascetic in order to convert him to Buddhism. Fear has become a weapon in the competition for followers; the creation of fear has become an important means of conversion.

If we look at one of the most important stories of missionary activity in the Pāli literature - the visit of the Tathāgata to Lañkā in the first chapter of the Mahâvamsa - we get a strong impression of the importance of fear in the spread of Buddhism to new territories. In fact, the Mahâvamsa sets the visit of the Buddha to Ceylon in the context of the conversion of the jatilas. During the Buddha's campaign of proselytizeing among the matted hair ascetics, Kassapa of Uruvelā prepares for a great sacrifice. The Buddha reads the mind of Kassapa and sees that he wishes the Buddha to stay away. This, of course, is part of the competitive stance of the relationship between the Buddha and the jatilas. Instead of appearing at the sacrifice of Kassapa the Buddha begs for alms and eats a meal, and then he goes to Lanika because he knows that the island will be a stronghold of his doctrine. When he arrives there is a great gathering of yakkhas living on the island:

To this great gathering of the yakkhas went the Blessed One, and there, in the midst of that assembly, hovering in the air over their heads, at the place of the (future) MahiyanganaThūpa, he struck terror (samvega) to their hearts by rain, storm, darkness and so forth. The yakkhas, overwhelmed by fear (bhaya), besought the fearless Vanquisher (abhaya jina) to release them from terrors, and the Vanquisher, destroyer of fear (abhayada), spoke thus to the terrified yakkhas: 'I will banish this your fear (bhaya) and your distress (dukkha), O 
yakkhas, give ye here to me with one accord a place where I may sit down.' The yakkhas thus answered the Blessed One: 'We all, O Lord, give you even the whole of our island. Give us release from our fear. ${ }^{.82}$

The Buddha descends among the yakkhas and dispels their fears and the cold and darkness. Then he preaches to the yakkhas, who are too shaken to put up any resistance, and converts them all to his Dhamma. In short, the Buddha uses certain techniques to induce fear (samvega and bhaya) in the potential converts and when they are sufficiently perturbed he promises to deliver them from their fear and distress. It seems that when the early Buddhists went out to win followers one of their strategies of proselytizeing was to induce fear in potential converts and, at the same time, offer a path to fearlessness. (This is, of course, a pattern familiar to social scientists who study conversion techniques in modern sects.)

This view of Buddhist missionary activity contradicts much of what has been said about the spread of the Buddha's Dhamma both by scholars and by Buddhist texts themselves. It is often said in the Pâli literature that the behaviour of the monks and nuns is supposed to bring satisfaction or pleasure ( $p a s \bar{a} d a$ ) to non-believers (appasanna) and increase the number of believers (pasanna). ${ }^{83}$ Dutt's summary of Buddhist missionary activity as relying exclusively on the excellent personalities of its propagators and the rationality of its doctrines is typical of a tendency among scholars to see Buddhism, and, more importantly, all its historical and geographical manifestations, as inherently peaceful, tolerant and cognitively pleasing. ${ }^{84}$ Wijayaratna points out that the Pāli texts constantly emphasize the need for monks and nuns to exhibit exemplary behaviour in front of lay people. As he asserts: 'The Buddha's teaching spread thanks to the exemplary conduct of his disciples. ${ }^{85}$ Lamotte seems to have had an ambivalent view of the early spread of Buddhism. On the one hand, he realizes that the Buddhist missionary activity involved zealous persuasion and even straightforward frightening of potential converts:

In order to gain the sympathy of the masses, the third century missionaries exploited the eternal themes of popular preaching, suitable for striking the imagination and provoking a psychological shock. The discourses listed by the chronicle struck all the sensory key-points in turn. The missionaries began 
by commiserating over the wretchedness of humanity, threatened by hell, condemned from all eternity to old age, disease and death, a slave to its own body and senses ... Then they celebrated the joy and peace which a virtuous and zealous man enjoys ... ${ }^{\text {, } 6}$

Interestingly, Lamotte builds his view of the nature of Buddhist missions, in part, on the contents of the discourses that the missionaries are said to have preached to the people of different countries and ends up with a picture that is very close to that of the preachers of hellfire and damnation that we are used to from medieval Christianity. However, on the other hand, he does not seem to be very comfortable with this position for he changes his view in the conclusion to the chapter on the Buddhist missions when he asserts that "private initiative played its part in the missionary movement, but the efforts of individuals fade before the intrinsic expansionary power of the Good Law which required nothing more than politically favourable circumstances to manifest itself. ${ }^{87}$

I think the idea that Buddhism spread primarily through its own inherent qualities is a naive view of missionary activity. The Buddhist texts themselves do indeed emphasize the exemplary conduct of the members of the Samgha and the inherent qualitites of the Dhamma, but when we try to reconstruct actual Buddhist missionary activity in Asia a blind trust in such assertions is misguided. References to 'fire and brimstone preaching' are not at all prominent compared with the references to mendicants who light up the world with their holiness. But this is only what we should expect. The few references that contradict the general impression of peaceful conversions are the most interesting for a study of religious motivation. It is not altogether unlikely that a number of references to mission in Buddhist texts might have been invented or revised in order to make the Dhamma seem like the natural religion that people of all countries embrace happily, whereas in reality it was preached with far more fervent techniques of persuasion. ${ }^{88}$

As we saw in the simile above, the Dhamma of the Buddha is supposed to make gods and men tremble and shake - like animals hearing the roar of the lion - and adopt the religious life which leads to freedom from fear. Fear is presented as a fact of samsāric existence just like pain or unease $(d u k k h a)$. We saw above that, 
according to Buddhaghosa, the four noble truths can be understood as fear (bhaya), the origin of fear (bhayamūla), the freedom from fear (nibbhaya) and the means to attain this (tadadhigamupāya). A characteristic of Buddhist philosophy and soteriology is its stress on the point of departure. The situation of living beings is one of pain and fear, the Pāli texts say, and they explains what this situation entails and how it originates. This emphasis on the point of departure, the situation from which one must seek deliverance, gave early Buddhism a particularly dynamic missionary stance. The sense of urgency created in potential converts through this strategy probably made them more receptive to the missionary efforts of the Buddhists.

The weapon of fear has been part of the missionary arsenal of Buddhists and perhaps other Indian traditions, but again fear is worthless without its negation, freedom from fear, and the ability to induce fear must be seen in conjunction with the ability to relieve fear and soothe the minds of people in distress. The Buddha induces fear and he is the bestower of fearlessness (abhayada), as the Mahāvamisa says. According to Mahāyāna mythology, Avalokitésvara typically bestows fearlessness on terrified beings (bhītānām sattvānām abhayam dadāti) and a common epithet of this popular bodhisattva is abhayada. ${ }^{89}$ Another figure of the Mahāyāna pantheon who is associated with freedom from fear is Amoghasiddhi. He is the one of the Dhyānī Buddhas and is depicted iconographically with his right hand showing the sign of no fear, abhayamudrā.

We may note that the gift of no fear (abhayadāna) is an important aspect of the life of the Indian renouncer in the Hindu tradition too, although here it takes on a very different role. The renouncer must give the gift of no fear to all beings. The Hārī tasmr ti, for instance, prescribes the vow of abhaya towards all beings for the person who is about to become a samnyāsin..$^{90}$ Sprockhoff has discussed the gift of no fear in the context of the adoption of the life of a saṃnyāsin (samnyāsasvīkāra). According to Sprockhoff the samnyāsa ceremony has three core elements, among which is the gift of no fear to all beings. ${ }^{91}$

\section{Conclusion}

Fear is an essential aspect of samsāric existence and the goal of the life of the renouncer is attaining the stage at which there is freedom 
from fear. Fear is, in other words, a painful thing from which human beings should try to free themselves. On the other hand, fear is absolutely necessary. Without fear nobody would strive for religious realization. Without fear nobody would exert themselves to achieve deliverance from fear. Thus, fear becomes a sine qua non of religious motivation in many Buddhist texts.

The point of departure for this chapter was the initial appearance of a contradiction in the treatment of fear in Indian religions and, in particular, in Buddhism. The solution to this puzzle is the fact that fear has very different functions under different circumstances: it is the talents and discipline of the individual that makes the difference. The advanced are able to apply fear in a constructive way, as a motivating factor in their religious life. In those who are not able to channel fear into religious motivation it is just a confusing and destructive feeling creating problems in everyday life.

I mentioned at the beginning of this chapter that the links between fear and religion have been a valid topic of scholarly investigation in anthropology and psychology in the West. In a study that attempts to say something about experiences which are so basic to human existence across cultures it seems reasonable to return to a general angle of approach in the concluding comments. We saw that fear of sickness and death was a basic idea in the Buddhist material I have examined. If we adopt a bird's-eye view of human religiosity, it seems that fear is a basic factor of human emotional life but that, although it is addressed by religious doctrine, there does not seem to be a straightforward relationship between beliefs and fear. To put this statement in perspective let us look at some data from a non-Indian context. The relationship between fear of death and religiosity has been the point of departure for a substantial number of social scientific studies in a modern Western, in most cases Protestant Christian, setting. Still, the relationship is an elusive one and no certainty has been achieved as to the exact correlations or the possible causal connections because there have been a number of different findings. Some researchers have discovered negative correlations between religiosity and fear, others have found positive correlations, and others again have not found any significant correlation whatsoever. The confusion is due to different methods, different definitions of fear or religiosity and different samples in the different studies. One serious shortcoming is the lack of distinction between different aspects of fear of death and religion. 
In the studies that have taken this problem seriously, however, it seems that one can detect a certain negative correlation between religiosity and the fear of at least certain aspects of death. Hoelter and Epley, for instance, broke fear of death into distinct dimensions. ${ }^{92}$ Using their multidimensional scale they found that religious people are less likely to fear the unknown aspects of death. They suggested that religiosity may serve to reduce these aspects of fear by dealing directly with them through the belief system. ${ }^{93} \mathrm{~A}$ more recent study by Thorson and Powell concluded that people who are more religious are less concerned with death. In their study those who had more anxiety concerning death were lower in religiosity. ${ }^{94}$ These researchers also used a multidimensional scale, which brought out some of the subtler points of their findings. For instance, it seems that one reason for the lower anxiety among the more religious is the fact that they look forward to an afterlife. ${ }^{95} \mathrm{~A}$ negative correlation between fear of death and belief in an afterlife is also reported by Osarchuk and Tatz. ${ }^{96}$

If we compare these modern Christian examples with our ancient Indian texts we have two large and multifarious religious traditions in different times and with fundamentally different beliefs about the nature of life, death and possible afterlives, and still one unambiguous parallel between the two is their preoccupation with and anxiety about death. As the Christian cases show, although the belief in an afterlife in heaven may make some people less anxious about death, clear correlations between beliefs and emotions in this area are more or less impossible to come by. Fear of death seems to be a universal phenomenon, and a prime undertaking of religious doctrines is to address this fear. Still, at least as far as the limited samples in this chapter are concerned, fear of death does not seem to vary significantly with different beliefs.

First of all, it seems unlikely that the double role of fear identified in Indian - and in particular Buddhist - material is exclusive to the religions under investigation here. I would think that fear could be both an aspect of the miserable state of human beings on earth and, at the same time, the motivational basis for religious striving, independently of the actual belief system in question. In order to complete the full circle we may return to the great Western writer on religious fear, Kierkegaard. For Kierkegaard despair and anxiety were key concepts of his religiosity. According to Kierkegaard, the possibility of despair is man's advantage over the beasts because it implies spirit, to become aware of the despair is the Christian's 
advantage over the natural man, and finally, to be healed of the sickness of despair is the Christian's bliss. ${ }^{97} \mathrm{By}$ acting on feelings of despair and anxiety and by embracing the Christian message a person can free himself from despair. In other words, despair becomes a motor in a religious process for Kierkegaard. It seems, then, that the role of fear as a motivating factor in religious life is not especially Indian after all. 



\section{RELIGIOUS MOTIVATION AND THE MERIT OF GIVING}

In Chapter 2, I suggested that the early Buddhist Samgha changed from a conversionist to an introversionist relationship to the world at least partly because a number of people joined the Samgha for the wrong reasons. They did not have the right religious motivation for being monks or nuns and therefore they damaged the image of the Samgha among lay people. The right image was important because the Samgha depended on the world outside for protection and for material support. In this chapter I wish to take a closer look at the metaphysical and ideological foundation of the relationship between Samgha and laity by looking at the ritual of giving to the Order of monks.

Any attempt to understand the social psychology of the relationship between the Buddhist Samgha and the laity must take into account the institution of giving. The thesis I wish to put forward here is that the classical Buddhist worldview contains fundamental contradictions that threaten to surface in the ritual of giving and receiving. In discussing these contradictions I hope to illuminate the ambivalent relationship between the monk and lay person, between Samgha and laity, that I looked at in Chapter 2 . Thus, I wish to continue my discussion of the fundamental issues of religious motivation in Buddhism from a slightly different angle from the previous chapters.

The general observation about the ambiguity of giving in Indian religions is not original. Indeed, the most puzzling character of the gift in an Indian setting is its ambiguity; several writers have pointed out that the Brahmin is reluctant to receive gifts. Мапи has a long list of hells with telling names - 'Excessively burning', 'Crushing', 'Iron Spike', 'Forest of Sword Leaves', etc. - that the unlucky Brahmin must visit if he were to accept gifts from the wrong person. ${ }^{1}$ 
The trouble with the gift for the Brahmin is that it forms unwanted bonds of dependency vis-à-vis the king, as Mauss observed in his classic study. ${ }^{2}$ But there is more to it than that. From the recipient's point of view the gift is potentially poisonous. The gift contains impurity, according to the writers who followed the Dumontian paradigm. Heesterman argued that the Brahmin officiant in Vedic times took over the death-impurity of the patron by accepting gifts, but that this role was fundamentally changed through the individualization of the ritual. ${ }^{3}$ Parry says that the Brahmins of Benares become living sewers as they received the death-impurity of mourners conveyed in the gift. ${ }^{4}$ The poison in the gift is really inauspiciousness (nāsubh), says Raheja in an important challenge to the Dumontian sociology of hierarchy based on impurity $(\bar{a}$ sauca $) .{ }^{5}$ Thus, new generations of sociologists and anthropologists were able to show that Mauss had been unable to account for the uniqueness of the Indian gift because he did not grasp the peculiar metaphysics of impurity or inauspiciousness.

There are two specific contradictions in the idea of the gift that I wish to discuss here. First, there is a contradiction in how the relationship between the giver and the recipient is perceived. On the one hand, the gift is seen as a sacrifice and the renouncer has taken the place of the gods on earth. On the other hand, it is seen as a charitable gift and the renouncer is a beggar. Second, there is a contradiction concerning the fundamental ethics of giving. On the one hand, the qualities of the recipient are thought to determine the merit of the gift. On the other hand, the intention of the giver is supposed to determine the merit earned. These two contradictions are interlinked. They may threaten to undermine the relationship between the renouncer and the householder. If it is the intention behind the gift that determines its results for the giver, there is no reason to distinguish between different types of recipients. Why, then, should anyone give to the renouncer? However, these contradictions seem to have been used creatively to invest all gifts with merit. When the gift is seen as a sacrifice the excellent qualities of the recipients are in the foreground. When the gift is seen as charity it is the good intentions of the giver that are highlighted. The good qualitites of the recipient ensure the merit in an act of sacrifice whereas the bad qualities of the recipient do not affect the merit in an act of charity. Gifts are never in vain if the giver can switch between the two alternative merit-making mechanisms as he pleases. 
Gift giving in Indian religion could be broken down and analysed in at least five parts. This is what the two main Jain traditions tend to do. They distinguish between the recipient ( $p \bar{a} t r a)$, the giver (dātr), the thing given (dātavya, dravya), the manner of giving (dānavidhi) and the result of giving (dänaphala). ${ }^{6}$ I wish to illuminate the relationship between the recipient and the giver. Therefore, I will limit my study to these two factors. I will refrain from going into the metaphysics of the thing given and engage instead in discussions about whether the giver gives part of himself in the gift and what sort of substance or quality may be conveyed.

My main material will be some central works on giving in Buddhist and Hindu literature: first, Pāli Buddhist texts such as the Khandhakas of the Vinaya Pitakas, the Dakkhināvibhangasutta and the Petavatthu; second, the Dharmásāstras, the Dharmasūtras and the Anu's āsanaparvan and the Bhagavdgītā of the Mahābhārata; third, I will use mainly secondary material to look at some ideas about giving in Jainism. I will also use inscriptions to some extent and draw on relevant ethnographic material. By looking at these texts I wish only to illuminate the contradictions mentioned above and have no intention of presenting an exhaustive analysis of the vast Indian literature on giving, a survey of which can be found in Kane's study of the dharmaśāstra literature.

\section{The giver}

First, I will take a brief look at the giver in a Buddhist setting. In the collection of his articles on the origins of Mahāyāna Buddhism, Gregory Schopen uses the evidence of inscriptions to show that the majority of donors to the Samgha were in fact monks and nuns themselves. ${ }^{7}$ This should make scholars devote more attention to the different forms of religious motivation among the members of the Samgha. Here, however, I am primarily interested in lay people as donors, because my overall aim is to investigate the dynamics in the relationship between the religious group and the outside world in order to understand the motivation that made people make the radical move from the world to the Samgha. In theory, the members of the Samgha are superior to the lay person in every way and they deserve unconditional respect and support. The lay person's potential power vis-à-vis the monks is suggestive of the ambiguous nature of their relationship. The Buddhist literature in Pāli has a number of different accounts that show how lay people have been 
in a position to influence not only individual decisions of the monks but the whole structure of the Buddhist Samgha. This power derives from the monks' dependency on the support of the laity. For instance, in the Mahāvagga X there is a story about a monk of Kosambi who is suspended for a certain offence. The monk does not accept his punishment and a group of monks takes his side against the group that has suspended him and a dispute arises in the Samgha. There are attempts to solve the dispute within the Samgha, and the Buddha is drawn into the problems, but the matter is not settled until the lay followers of Kosambī also flex their muscles against the Samgha. They decide to put pressure on the trouble-making monks by withdrawing all their respect and offerings. From the Pāli literature it is clear that this kind of pressure from lay people had to be taken seriously. When in Mahāvagga I.43 (MV I.43) a thief goes forth among the monks, people talk negatively about this. ${ }^{8}$ The Samgha is forced to react to the criticism from members of the laity because they are materially dependent on them. In MV II.2 the monks gather on the fourteenth, fifteenth and eighth days of the half-month. People come up to them to hear Dhamma but the monks sit in silence. The people get angry and ask how the monks can sit in silence like dumb pigs ( $m \bar{u} g a s \bar{u} k h a r \bar{a})$. To meet the negative feedback, the Buddha orders the monks to recite Dhamma. In MV I.25 monks go begging wrongly dressed and they are greedy and eat in an unbecoming manner. People react negatively to their bad behaviour, and because of their reactions the Buddha allows preceptors. In MV I.32 the monks are subject to criticism when they behave badly after their preceptors leave or die, so the Buddha allows teachers in order to meet the criticism. In the MV II monks walk around during all seasons, including the rains, trampling down crops and grasses and destroying many little creatures. People react to this and as a consequence the Buddha makes rules for life during the rainy season. This sequence of events is repeated again and again in the Khandhaka section of the Vinaya Pitaka, and I discussed some of this material in Chapter 2.

The point is that there appears, from the Pāli texts, to have been a constant pressure from the laity on the monks to behave according to the rules. The tension between givers and recipients also seems to be a prominent feature of Theravāda Buddhist sociology of modern times. As Spiro observed of Buddhism in Burma, to persistently maintain a class of human beings as demigods and 
watch them live in luxury and ease while one toils in the fields must create ambivalence towards the monks. ${ }^{9}$

It is clear that the giver has certain powers vis-à-vis the recipients in Indian religions. Communities of renouncers are dependent on the society for their subsistence and the householders or lay people are in a position to withdraw support if the recipient does not satisfy certain criteria. On the other hand, the giver, too, must have certain qualities. Texts on giving from the Hindu, Buddhist and Jain traditions emphasize that the person who gives alms must have the correct attitude towards the recipient. The Digambaras have established a set of qualities that should be present in a worthy giver of gifts. These are: faith ( $s r a d d h \bar{a})$, which means confidence in the results of the donation; devotion (bhakti), which means love for the virtues of the recipient; contentment or joy in giving (tusti $i)$; zeal (sattva) in giving; disinterestedness or lack of desire for worldly rewards (lobhaparityāga); and patience $(k s a m \bar{a}) .{ }^{10}$ The $\bar{S}$ vetämbaras have several different lists of qualities in a giver. Among the qualities given by one such list, in the Tattvārthabhāsya, we find the word aparibh $\bar{a} v i t v \bar{a}$. This word is from the root pari-bh $\bar{u}$ which carries meanings such as 'be superior to', 'subdue', 'despise', etc. Williams translates aparibhāvitva as 'absence of condescension towards the recipient' ${ }^{11}$ In other words, the giver should have a frame of mind in which he does not think of himself as superior to the recipient. The condescension that naturally arises in the charitable donor towards the beggar would undermine the structure of the relationship between monk and lay person if it were allowed to exist and be expressed.

Why does the giver give gifts? Indian religions share a belief in rebirth. When a living being dies, some part of it does not disappear with the physical body but is reborn in a new state. If one has acquired merit, in Pāli, puñña, one is reborn as a human being or as a god in a world of gods, devaloka. If one has acted badly and not acquired merit, one is reborn as a lower life form or in a dreadful hell. Therefore, it is important to earn merit. In Buddhist texts there is often said to be three ways of doing this: dāna, giving, sìla, good conduct, and bhāvanāa, contemplation. Each of these is a puñnakiriyavatthu, a thing that leads to merit. Admittedly, the issue of merit is not always explicitly brought out in Buddhist material on giving. Paranavitana has collected over 1,200 inscriptions in Ceylon made between $300 \mathrm{BC}$ and $\mathrm{AD} 100$ registering donations, 
often of caves, to the Samgha. Here donors give their names and often their relation to a member of the Order. However, no mention is made of the desire to gain merit. If they say anything at all about their motivation, the donors simply state that they give gifts for the benefit of the Samgha. ${ }^{12}$ Respect for, and devotion towards, the Buddhist Samgha is undoubtedly an important motivational factor. Still, it is reasonable to say that the idea of merit making is the metaphysical foundation of such donations.

The giver gives in order to acquire merit. Acquiring merit may lead to a favourable rebirth. However, in order to attain salvation in a real sense, one must, first, be reborn in the state of a human being, in which neither pain nor pleasure is too overwhelming to contemplate salvation, and, second, follow the right practice. This cannot be done as a householder. The Buddha said: 'Vaccha, there is no householder who, without abandoning the fetter of householdship, on the dissolution of the body has made an end of suffering. ${ }^{\prime 3}$ To attain Nirvāna one must first of all become a monk or nun. ${ }^{14}$ However, says the Buddha, a very large number of householders have gone to heaven on the dissolution of the body.

The idea of merit making was pan-Indian. In the numerous inscriptions recording grants of land to Brahmins during the late fifth century AD the merit acquired from the gifts was thought to "erect a ladder leading to heaven (svargasopānapaikkti). ${ }^{15}$ Another standard phrase accompanying grants was that the donation was given to increase the merit (punya) for mother, father and self and in order to obtain a reward (phala) both in this world and in the next. ${ }^{16}$ Often, grants of land are thought to ensure 60,000 years in heaven for the giver, but merit is never thought of as leading to complete salvation. Against the ethics of merit and favourable rebirth stands the path of the uncompromising salvation-seeker. Whereas the lay person needs to do good deeds, the ascetic aims at doing nothing. The essential question of what doing nothing really means is answered in different ways by different religions in India. Through some form of ascetic practice the monk or renouncer can stop the influx or generation of new karma and get rid of karma that has been accumulated from earlier actions. To the ascetic, merit is basically no better than demerit because both tie him to samsāra. The medieval Jain author Kunda Kunda said: 'A gold fetter binds a person as much as an iron one. Similarly good or bad deeds performed bind the soul. ${ }^{17}$

Let us look briefly at some Jain ideals of giving to illuminate 
the difference between the ethics of the lay person and the ascetic. It has been noted that there is a paradox in the way that Jains practise the danavrata, the vow of giving. ${ }^{18}$ Reynells suggested that when ostentatiously donating costly gifts, wealthy Jains seem to be breaking the vow of aparigraha, non-attachment to worldly possessions. ${ }^{19}$ Norman has picked up this topic and tried to show that no paradox is involved. ${ }^{20}$ There is no canonical injunction against giving openly, he says. One could also point out that several prominent Jain authors have listed ostentatious giving as the practice of a good layman, and Williams has shown that this is the case.

In Digambara Jain classifications of giving, dāna or datti, the concept of samadatti, gifts to equals, is one type. ${ }^{21}$ According to the medieval Jain teacher Jinasena, the celebrated author of the Mahäpurāna, samadatti is the giving away of gifts, such as land, gold, horses, elephants, chariots and daughters, to a recipient who is equal to oneself in terms of status and piousness. Another medieval Jain author, Āsāadhara, distinguishes between gifts that are made for the sake of one's well-being in a future life and gifts that are made for one's well-being in this life. To the last category belong the flashy gifts such as gold, horses, elephants and daughters. ${ }^{22}$ The distinctions between alms-giving and ostentatious giving are not clear-cut. There is no reason why an ostentatious act of giving should be less meritorious, as long as the giver has the qualitites that are required, among which are, admittedly, disinterestedness. ${ }^{23}$ Hemacandra, who sets the standards for Śvetāmbara śrāvakācāra with his Yogásāstra, also seems to prescribe a certain degree of lavishness. If one does not sow wealth openly and constantly, one cannot achieve the right conduct, he says. ${ }^{24}$ As Cort has pointed out, it seems that we can get a deeper understanding of Jain giving if we realize that there is an alternative ideological framework that centres on well-being and balanced living in society, including, of course, piousness and alms-giving, rather than isolation and moksa. ${ }^{25}$

Giving produces merit for the giver. However, in some Buddhist texts we are told that it is possible to transfer to others the merit that is earned by giving to the Samgha. This is illustrated by the story of Nandā in the Petavatthu. Nandā was the wife of the householder Nandasena who lived in a village not far from Sāvatthī. Nandā was irreligious and disrespectful toward her husband, and when she died, she was reborn as a petī, an ugly and suffering ghost. One day Nandasena meets the ghost who had been his wife 
in a previous life. At first, the widower does not recognize his beloved behind the terrible appearance of the pet $\bar{\imath}$, but when she tells him her story, he wishes to lead her home and give her food and clothes and let her see her children. However, Nandā knows that her husband would not be able to help her in a direct way:

What is given by your hand into mine does not profit me. But as regards the monks, who are abounding in the moral precepts, free from passion, and learned, / Regale them with food and drink and transfer to me the benefit of the gift. Then I shall be happy, blest in the fulfilment of all desires. ${ }^{26}$

Nandasena follows his wife's advice and makes abundant gifts to the monks and transfers the merit to Nandā. As a result she is able to come out of the world of petas and join her husband and enjoy food and wear clothes. The practice of merit transference clearly contradicts the Buddhist theory of karma, which says that an individual is totally responsible for all his acts and must bear their consequences alone. One's fate after death cannot be influenced by others, according to canonical Buddhism.

It is the same for Hindu cosmology. According to Manu: 'A living creature is born alone and alone he dies; he alone reaps the benefits of good deeds and the consequences of bad deeds. ${ }^{27}$ Still, we find the practice of merit transference abundantly documented in Hindu sources. We have a large number of inscriptions from the late fifth century AD, or the late Gupta period, collected by J. F. Fleet, recording grants of land to Brahmins. The motivation behind the donations are often explicitly stated and are essentially the same as in Buddhist and Jain sources. One, Mahārāja Hastin, has recorded a number of grants of land to Brahmins and he always gives the same motivation for doing so: he wishes to increase the merit of himself and of his parents. ${ }^{28}$ The Mahārāja Jayanātha gives the same reasons for giving grants of land to Brahmins: it is for the increase of his own merit (svapunyābhivrddhaye) and for the benefit of the feet of the Lord (Bhagavatpāda), i.e. Viṣnu. Another, Dhanyaviṣnu, says that he has built a temple to Viṣnu the Boar in order to increase the merit of his parents..$^{29}$ And another, Mātrcheța, says that he has built a stone temple to the sun in order to increase the religious merit of himself and his parents. But religious merit cannot only be transferred over one generation. Almost all the records of grants of land to Brahmins state that the merit produced by a gift of land 
is not exclusive to the original donor but is shared by all his predecessors as long as they do not reclaim the land, in which case they go to hell for an extended period. ${ }^{30}$

The Jains have always insisted that acts and their fruits are exclusively the responsibility of the individual. In the words of the tenth century $\bar{a} c \bar{a}$ rya Amitagati: 'Except for karma earned for oneself by oneself, no one gives anything to anyone. ${ }^{31}$ According to P. S. Jaini, the Jains have been able to keep out practices that contradict the individual idea of karma such as śräddha and transference of merit. ${ }^{32}$ Why did the practice creep into Buddhism? It has been suggested that the transference of merit in Theravāda Buddhism was a borrowing from Mahāyāna doctrine in which bodhisattvas can save others by their enormous store of merit. ${ }^{33}$ According to Gombrich, however, the practice of merit transference originated out of emotional needs to escape the responsibility of orthodox karma doctrine. By transferring merit one could improve the situation of dead relatives, and one's own state after death could be influenced in the same way. When dead relatives received merit, they were thought to say 'thank you', anumodati. Orthodox writers wished to integrate the practice with the laws of karma. They said that in reality no merit was transferred and the dead did not give thanks; they simply rejoiced in the good deed. Anumodana meant rejoicing not thanking. ${ }^{34}$ However, the orthodox solution does not necessarily destroy all hopes that one can influence the karma of others. When one can rejoice in the good deeds of other people to the extent that one is reborn as a god, what does it matter that one cannot really give gifts of merit? This seems to be the attitude among many Theravāda Buddhists of today.

\section{The recipient}

The first lay followers of the Buddha were the two merchants, Tripusa and Bhallika, who chanced to pass by the place where the Buddha was sitting right after his enlightenment. When Tripusa and Bhallika presented the Buddha with food, it was for their welfare, benefit and happiness for a long time (dīrgharätram arthāya hitāya sukhāya) says the Catusparișatsūtra. Moreover, the Buddha accepted the alms for the welfare of beings (hitāya prāninām). When receiving alms, the Samgha does the favour of giving the laity the opportunity of earning merit. Under special circumstances, the Samgha may refuse to accept the alms of a lay 
follower. In Cullavagga V.20 the begging bowl is turned upside down on the lay follower Licchavi Vaddhha, and he is suspended from eating with the Samgha. He has lied about the chastity of the venerable Dabba the Mallian and the Buddha decides the proper reaction. It is Annanda who informs the transgressor about his punishment. The Buddha has decreed that if a lay follower is possessed of certain bad qualities, the monks should turn the begging bowl on him, in other words they shall refuse to accept alms from him. This means that he cannot earn merit, and one can easily imagine that it also means social disgrace. Evidently, the turning upside down of the begging bowl on a lay follower was quite a penalty, for when Ānanda told Vaddha about the decision of the Samgha the poor man fainted and fell on that very spot. Fortunately for the Licchavi, the Buddha also allows the monks to turn upright the bowl on a lay follower. ${ }^{35}$

The renouncers, whether Hindu, Buddhist or Jain, often seem to be under some sort of obligation to accept the gifts presented to them. In order not to accept there must be some fault in the giver or the gift that makes the giving valueless or harmful. The opportunity to give is at the same time an opportunity to invest in the future for the donor. What is given is thought to increase manifold either in this life or in the next. In the Hindu Dharmaśāstra literature, as well as in the Anuśa asanaparvan, there is often some sort of association between what is given and what is received later as a result of the gift. If one gives a lamp, one may get good eyesight in the next life; if one gives a pair of sandals, one may get an excellent vehicle for travelling; if one gives food, one will get to eat in the world beyond; if one gives the gift of non-injury to beings, one will enjoy excellent health, etc. Gifts are investments, and their interest rates may be extremely high, if we are to believe Brahmin and monk writers.

In spite of the obligation to receive gifts, a recurring theme in the behaviour and the ideology of the recipient is an initial unwillingness to accept. Here we touch on the fundamental ambiguity of the institutionalized giving. Marcel Mauss observed:

The recipient puts himself in a position of dependence vis-àvis the donor. This is why the Brahmin must not 'accept' gifts, and even less solicit them, from the king, and would demean himself if he did anything other than take gifts. ${ }^{36}$ 
For the Brahmin the gift is dangerous to accept, Mauss says, because of the bonds that are established in the gift. The same danger is found in Buddhism and Jainism. The monks do not solicit gifts, they only put themselves in a position in which it is convenient to give them food. There is a constant need to maintain the fiction that the Brahmin, the ascetic or the monk is not dependent on the householder and that the asymmetry in the relationship between giver and recipient is the natural thing. The recipient reluctantly accepts what is offered as a favour to the giver. Laidlaw observes that for the Jains the giving to the renouncer does not really take place. By denying that supatradan, gift to the good recipient, is a dan (gift), the householder frees the renouncer from any dependency. ${ }^{37}$

We saw that the giver is expected to possess certain qualities. The same is the case for the recipient. In his exposition of the Samgha the great Buddhist writer Buddhaghosa explains that a gift is something given with thoughts of the next world. ${ }^{38}$ The wish for, and the possibility of, acquiring merit for the next world by giving to monks is the basis for the institution of alms-giving. The idea of the Buddhist monks and the Samgha as a field of merit (puñ$\tilde{n} a k k h e t t a)$ is found in a number of Pāli texts, both canonical and post-canonical. In the Pătika Suttanta the Buddha says that the Order should be respected and revered and given gifts and homage; it is the world's unsurpassed field of merit. ${ }^{39}$ Likewise, in the Sangiti Suttanta the Samgha is again described as the world's unsurpassed field of merit. ${ }^{40}$ In the first story of the Petavatthu the field of merit, embodied in one monk, provides the opportunity to achieve a good rebirth in a seemingly mechanistic and straightforward manner. Here the elder Moggallāna sees a thief who is about to be executed. In order to save him from rebirth in hell, the monk approaches the thief and accepts a gift of sweetmeat and water from him, and because Moggallāna is an unsurpassed field of merit the thief is reborn in a world of gods. According to the Petavatthu, the Buddha explained how this is possible in the following manner: 'Like unto fields are the Arahants; the givers are like unto farmers; resembling seed is the gift; from this is produced fruit. ${ }^{41}$ Buddhaghosa explained the meaning of the concept of field of merit in his chapter on the Samgha. ${ }^{42}$ He says that the Samgha is called 'The world's unsurpassed field of merit' because the Samgha is a place where the merit of the world can grow. Just as the field where the king or 
his councillor sows rice or barley is called 'the rice or barley field of the king', in the same way the Samgha is a field for the growing of merit. The Jains also have the idea of the Order of monks as a field of merit. According to Williams, the early Jain author Haribhadra uses the term ksetra in this sense twice in his Dharmabindhu.$^{43}$ The great medieval writer Hemacandra enumerates seven ksetras in which the layman should sow his wealth. These are Jain images, Jain temples, Jain scriptures, monks, nuns, laymen and laywomen.

The lay person can sow good deeds in the field of merit, but the quality of the soil determines the harvest. In Theravāda Buddhism, the qualities of the recipient of a gift are often said to determine the merit that the gift produces for the donor. For a gift to be efficient in terms of merit, the monks should, first of all, be of pure conduct. There is also the idea that the longer a person has been a monk, the greater is the merit produced from giving him alms. The Cullavagga IV is concerned with questions of the purity and dignity of the Samgha in the eyes of monks and lay people. For instance, one story tells about a group of monks who are constantly offered inferior food by householders because they are newly ordained and of little merit. One day these monks go to a meal and the householder giving the meal makes them sit on the porch and gives them only broken rice and sour gruel. Naturally, the newly ordained monks are not happy about their treatment.

According to the Dakkhināvibhangasutta, the Buddha distinguished between gifts to individuals and to the Samgha. ${ }^{44}$ Gifts to individuals (pātipuggalikā dakkhin̄a ) are of fourteen types. The first type is to a Tathāgata and the last type is to those who have been reborn as animals (tiracchānagata). Between these two extremes there are a number of different individuals to which one may donate. Gifts given to those reborn as animals increase a hundredfold, whereas a gift to a Tathāgata is meritorious beyond expression. The same hierarchy of recipients and merit are found in modern Burmese Buddhism. The feeding of a hundred dogs is equivalent in merit to feeding one human being, the feeding of one lay person is equivalent to one novice, a hundred novices equals one monk, etc. ${ }^{45}$ In the Dakkhina âvibhangasutta donations to the Samgha are of seven types. These are distinguished by three criteria: whether the Buddha is the leader of the Samgha or the donation takes place after his death; whether one gives to the whole Samgha or only to parts of it; and whether it is given to monks or nuns. 
Never is a gift to an individual of greater fruit (mahapphalataram) than a gift to the Samgha as a whole. But, says the same text, gifts can be given by worthy donors to unworthy recipients because the gift is purified or hallowed (visujjhati) by the giver (dāyaka). Even if a gift is given by an unworthy donor to an unworthy recipient, it is still fruitful, says the Buddha. Here we are at the heart of the ideology of gift giving. The Dakkhināvibhangasutta uses the contradictory ideas of merit making to show that gifts are meritorious under all circumstances.

In Jainism there have been different opinions on the question, but in general Jains use a fivefold classification of recipients set out by the medieval writers Amrtacandra, Amitagati, Vasunandin and Âsâdhara. In their list the best recipient is the Jain ascetic, the next best is a Jain layman who is on his way up the scale of religious realization that at some point ends in monkhood, the least satisfactory recipient is a non-practising layman who has the right belief, a poor recipient is a person of righteous life but without the right belief and the wrong recipient is person devoid of both right belief and good conduct. ${ }^{46}$ Another important Jain author, Somadeva, has a list of different recipients based on the aspect of the religion in which they specialize. Astrologers and specialists in practical sciences constitute one type, orators and debaters and writers another type, etc.

A similar hierarchical order of gift and merit is found in Hinduism. Manu says 'A gift to a non-priest yields the basic (reward); to someone who says he is a priest, double; to a teacher, a hundred thousand (times); and to one who has crossed to the far shore of the Veda, endless (reward). For a small or great reward for a gift is obtained after death according to the particular qualities and the amount of faith of the recipient. ${ }^{, 47}$ This is a basic theme in the Dharmaśāstra literature. The Yajñavalkyasmrti says that both asceticism (tapas) and learning (vidya ) must be present for a person to be worthy of a gift. A person who lacks either must not accept donations. ${ }^{48}$ Right learning and right conduct seem to be two general qualities that should be present in the recipient of a gift in Hindu thought. Мапи says that a king must ascertain the presence of learning and virtue (srutavrtta) in an ascetic in his realm. If these qualities are present, the king must protect him in every way, like a father protects a son. ${ }^{49}$ When the king has confiscated the property of criminals, he may choose to give it to a Brahmin who is possessed of learning and virtue (srutavrttopapanna).$^{50}$ As the farmer who 
sows seed in barren soil reaps no harvest, so the donor who gives the offering to someone ignorant of the Rg Veda obtains no fruit. ${ }^{51}$ Manu has long lists of those who are unworthy of offerings. ${ }^{52}$

In the Mahābhārata, Bhīṣma tells Yudhișthira that a priest of the sacrifice ( $r$ tvij), a family priest (purohita), a teacher, a disciple, relatives and kinsmen can be considered worthy of worship and honour if they are furnished with learning and virtue (srutavrttopasamhita) ${ }^{53}$ Other important qualities in a recipient, according to Bhīsma, are absence of anger (akrodha), truthfulness in words (satyavacana), non-injury to beings (ahimsāa), self-control (dama), sincerity (ārjava), absence of malice (adroha), absence of pride (nātimāna), modesty (hri) , patience (titikșa), asceticism (tapas) and tranquillity (sama). A person who has these qualities is considered to be the right recipient (pätra).$^{54}$ The quality of ahims $\bar{a}$ is often said to be a necessary quality of a worthy recipient of gifts in the Anuśa āsanaparvan. Non-injury to others is associated with one's own health. ${ }^{55}$ Moreover, the accepting of gifts is surrounded by a number of rules. If one accepts gifts without observing these rules, it will have disastrous consequences: 'If he does not know the rules regarding the law for accepting material objects, a wise man should not accept (gifts), even if he is fainting with hunger. An ignorant man who goes about accepting gold, land, a horse, a cow, food, clothing, sesame seeds and clarified butter is reduced to ashes, as if he were wood. ${ }^{56}$

M. E. Spiro says that the Burmese have reversed the relationship between donor and recipient in that the merit in giving derives from the spiritual qualities of the recipient, not from the qualities of the donor. ${ }^{57}$ As we have seen, this is no reversal or innovation, but is an essential aspect of the idea of giving in Buddhism, Jainism and Hinduism. Perhaps the most telling examples of this are found in stories in Buddhist literature in which thieves and murderers are reborn in heaven because they give gifts to prominent members of the Samgha.

\section{Sacrifice and charity}

From the above we may conclude that there is a large number of rules pertaining to the giving and the receiving of gifts in Indian religion. But there also emerges a fundamental ambiguity. On the one hand, the gift is a sacrifice and the giver has an obligation to perform it. If the monks or the ascetics, who have taken the place 
of the gods on earth, refuse to accept the gift, it has negative consequences for the donor. On the other hand, the renouncer is a poor beggar who is completely dependent on the charity of householders. As Trautmann has suggested, gifts can be imagined in two fundamentally opposite ways. On the one hand, the gift can be seen as going upwards to superior beings. On the other hand, it can be seen as going downwards to dependants..$^{58}$

The paradigmatic action in the Vedic worldview was the sacrifice, yajña. The most important sacrifices were complex and time-consuming. The relationship between the king and the priest, between the sponsor and the sacrificer, was likewise the paradigmatic social relationship in ancient India. Oldenberg suggested that the purohita functioned as the alter ego of the king in Vedic religion. ${ }^{59}$ Through the merit acquired by the correct performance of the Vedic sacrifice, the sacrificer made for himself, in addition to worldly benefits, a loka, in the Atharvaveda often called a sukrtäm loka - the sphere or condition of those who have earned the rewards of well-performed rites - or a sukrtasya lokathe sphere of ritual and religious merit. ${ }^{60}$ The substantive sukrtam denotes the merit, the positive results of the correct performance of the sacrifice. According to Gonda: 'This idea runs therefore in the ritual sphere of Vedism parallel with - or it is in this sphere the predecessor of - what in later times when the doctrine of transmigration has fully developed is, with a derivative of the same root $k r$-, called a man's good karman ... ${ }^{61}$ Thus, in Vedic religion correct ritual was the means to make merit. This would soon change, however. When the idea of transmigration and repeated death was fully developed the idea of complete release from the cycle of rebirth came to be the ultimate soteriological goal and at the same time the Vedic sacrifice lost its significance. Perhaps around the middle of the first millennium BC, there took place significant changes in the conception of the sacrifice. The Mundaka Upanișad attacks the Vedic ideas of ritual: 'Deeming sacrifices and gifts as the best, the imbeciles know nothing better. ${ }^{62}$ However, wise people know, as the Kaușitaki Upanișad says, that when one breathes, speech is offered in breath and when one speaks, breath is offered in speech, and: 'It is because they knew this that people in ancient times refrained from offering the daily fire sacrifice. ${ }^{63}$ The fire of the Vedic sacrifices burns inside the ascetic, and it is there that the real sacrifices are performed. The ascetic, samnnyāsin, is one who takes the sacred fire from the hearth and places it within himself. As it is 
written in the Samvartasmrti: 'By placing the sacred fire within himself, a twice born person should adopt the life of mendicancy. ${ }^{64}$

With the rise of Buddhism and Jainism the real sacrifice came to be the gifts to the order of monks instead of the traditional Brahminical rituals. In the Kütadantasutta the Brahmin Küțadanta approaches the Buddha to learn about sacrifices. The Buddha tells him about bloodless sacrifices. Alms-giving and the building of monasteries are much better in terms of merit and easier to perform than the traditional sacrifices of the Brahmins, the Buddha asserts. ${ }^{65}$ This idea is also found in Hindu thought. Manu says: 'What is offered as an oblation in the mouth of a priest is better than daily fire sacrifices; it is never spilt, dropped or destroyed. ${ }^{\prime 66}$ But how can the giving of food to religious specialists be a substitute for sacrifice to the gods? Marcel Mauss believed that in alms-giving humans have taken the place of the gods. But, as he also observed, the giving of alms has a double nature:

Alms are the fruits of a moral notion of the gift and of fortune on the one hand, and of a notion of sacrifice, on the other. Generosity is an obligation, because Nemesis avenges the poor and the gods for the superabundance of happiness and wealth of certain people who should rid themselves of it. ${ }^{67}$

We have moved our focus to another aspect of gift giving which has been little commented on in connection with Indian religion: charity. This topic is often met with in the Dharmásāstra literature. The Atrismrti prescribes charity thus: 'He who gives food during famine [durbhikșa]; he who gives gold in a prosperous time [subhiksa]; and he who gives water in a forest fares gloriously in the celestial regions. ${ }^{68}$ The Samvartasmrti says: 'By an intelligent person, seeking his own well-being, these gifts and others should be made specially unto the poor, the blind and other distressed persons. ${ }^{69}$ Giving for charity has a long tradition in Jainism. The practice of giving to the needy regardless of religious and social affiliation is karunadana, the gift of charity. The medieval Digambara writer Vasunandin says that one should give not only to monks, but to the very young and the very old, the blind, the dumb, the deaf, strangers from another land and to the sick. ${ }^{70}$ Āsādhara, another medieval Digambara writer, prescribes the giving of food, water and medicines regardless of faith. The greatest of all medieval Jain authors, Hemacandra, also says that charity should 
be practised towards those who have fallen into evil circumstances. ${ }^{71}$ The karunadana found in Jainism is closely related to another important religious vow of the religion, the ahimsāvrata, the vow of non-violence, and to the abhayadāna, the gift of no fear, which is an important aspect of ahimsā. The Yajnavalkyasmrti lists the gift of no fear (abhaya) among gifts that makes the giver happy. ${ }^{72}$ The Hāritasmrti prescribes the vow of abhaya, non-fear, towards all beings for the person who is about to become a samnya $\overline{s i n} .^{73}$ The Brhaspatismrti prescribes the protection of life (jīvarakșana), and says that beauty, prosperity and good health are the fruits of ahims $\bar{a} .^{74}$

The Daksasmrti says that the nine sacred works are giving food to the manes, the deities, human beings, the poor, helpless, the ascetics, the father, the mother and the preceptor. ${ }^{75}$ In other words, the gods, the ascetics and the poor are all essentially in the same boat because they depend on charity from humans who have wealth to give away. According to Manu, dānadharma is divided into sacrifice and charity, it is aistikpaurtika. ${ }^{76}$ In his commentary on Manu 4.5, Medhātithi says that a gift given through compassion (karunāa) cannot be counted as part of dānadharma. ${ }^{77}$ Such remarks suggest that the experts on dharmasās tra had problems with integrating the different strands of thought that came together in the giving of gifts. The blending of ideas of sacrifice and charity can be found throughout the literature on giving. In the beginning of the Anu's̄āsanaparvan, Yudhiṣthira asks Bhīṣma where one finds the greatest fruit; in the sacrifice or the charitable gift. What gives the highest reward - that which is given on the sacrificial platform (antarvedyam) or that which is given out of kindness (anr's amsatya or -ta)? However, Bhīsma refuses to distinguish between gifts and sacrifices. He says that by doing an act of giving (dānakarma), one must think of oneself as performing a sacrifice $(i s \underline{t a}){ }^{78}$ The Āpastamba Dharmasūtra is explicit in its identification of gift giving and sacrifice:

This reception of guests is an everlasting ('srauta)-sacrifice (yajña) offered by the householder to Prajāpati. The fire in the stomach of the guest (represents) the Āhavanīya, (the sacred fire) in the house of the host represents the Gārhapatya, the fire at which the food for the guest is cooked (represents) the fire used for cooking the sacrificial viands (the Dakṣināgni). ${ }^{7} 79$ 
The Āpastamba Dharmasūtra continues with a detailed account of symmetries between the different parts of food-offering and the sacrifices. The different actions during the meal given to a guest have exact parallels in the different actions during the sacrifice, just like the three fires of the sacrifice have their parallels in the fires of the stomach of the guest and the fires in the house of the host:

Food (offered to guests) which is mixed with milk procures the reward of an Agniștoma sacrifice, food mixed with clarified butter procures the reward of an Ukthya, food mixed with honey the reward of an Atirātra, food accompanied by meat the reward of a Dvādaśāha, (food and) water numerous offspring and long life. ... When he gives food in the morning; at noon and in the evening, (these gifts) are the Savanas (of that sacrifice offered to Prajāpati). When he rises after his guest has risen (to depart), that act represents the Udavasānīyā ișți (of a Vedic sacrifice). When he addresses (the guest) kindly, that kind address (represents) the Dakșināa . When he follows (his departing guest, his steps represent) the steps of Viṣnu. When he returns (after having accompanied his guest), that (act represents) the Avabhr tha (the final bath performed after the completion of a sacrifice. $)^{80}$

The sacrifice and the giving of food are identical in terms of merit. The same idea is found in the Vasisța Dharmasūtra, but here the body of a Brahmin is the sacrificial fire. When food is offered in the mouth of the Brahmin, this is the same as giving the sacrificial victim to the flames: 'A Brāhmaṇa is a fire. ${ }^{81}$ Again, we are given a long list of parallels and symmetries between the gift to a Brahmin and a sacrifice. The body of the Brahmin is the altar, his mouth is the Âhavaniya fire, the fire in his abdomen is the Gārhapatya fire, and the Dakșināgni is in his navel, the sense organs are sacrificial vessels, etc. ${ }^{82}$ Manu also says that the mouth of a priest is the fire in which one should offer sacrifices. ${ }^{83}$ The Anúsāsanaparvan 152.19 says that a Brahmin is a god and the Śatapatha Brāhmana says that there are two kinds of gods: those in heaven and the Brahmins. Sacrifice is divided in two: oblations to gods and fees to Brahmins. ${ }^{84}$

The blending of sacrifice and charity is seen in practice in Aśoka's accounts of his own work for the propagation of dharma. In the fifth rock edict of Kalsi, Aśsoka says that he has established 
a completely new office in his state; that of the Mahāmātra. The Mahāmātras are occupied with promoting dharma and in charitable work throughout the kingdom. ${ }^{85}$ In a number of rock inscriptions, Aśoka lists support of 'sramañas and brähmanas together with support of the aged and other types of charity, such as kindness to slaves and non-injury to animals. ${ }^{86}$ We can also see the blending of these ideas in inscriptions recording grants of land to Brahmins in the Gupta period. One donor says that the wealth (dhana) formerly given to Brahmins is like the remains of offerings to gods (nirmālya). ${ }^{87}$ For this reason no good and sane man would take such wealth back and we may infer that this is the reason why the discontinuation of a grant is associated with extreme accumulation of demerit.

In conclusion, there are two different strands of ideas connected with the religious gift in Indian religion, including Hinduism, Buddhism and Jainism. On the one hand, giving is sacrifice. The giver is a humble servant, whereas the recipient is a god or, in a gods place, an ascetic, who is deserving of gifts and does the devotee a favour by accepting. On the other hand giving is charity. The recipient is a poor beggar who must be kept alive by the wealthy householder.

\section{Merit and intention}

The sacrifice, especially in the Buddhist and Jain ideologies, became the ritual giving to the order of monks or nuns, and this giving was essentially the same as charity. It was the intention of the giver that was the important aspect of giving because the intention produced merit. The ethic of intention is prominent in the major Indian religions. The locus classicus for this ethic is the Bhagavadgi $\bar{\imath} \bar{a}$, in which Kṛ̣na tells Arjuna not to worry about his acts as long as his intentions are good. But the Bhagavadgit $\bar{t}$ does not escape the contradictions inherent in the ideas of giving. On the one hand, it emphasizes intention. It applies the ontology of the three gunas to both sacrifice and alms-giving and in both activities it is exactly the same qualities that distinguish the sāttvika from the rājasa and tammasa. ${ }^{88}$ In the sacrifice the desire to taste its fruits is the heart of the matter and, likewise, in giving alms it is the expectation of getting something in return that determines the quality of the act. When something is given in order to repay somebody or in order to enjoy the fruits of the act (pratyupakārārtham phalam uddis ya vā) 
then the act is of rājasa quality. On the other hand, however, the Bhagavdagi $t \bar{a}$ sees the sacrifice as the hub of a reciprocal relationship between gods and men. Gods and men sustain one another. In return for sacrifice the gods give the food of one's desire (iștāan bhogān), whereas those who enjoy their gifts without giving anything in return are simple thieves. ${ }^{89}$

For the Buddhists the basic causes of kamma were greed, hate and delusion; lobha, dosa and moha. The Buddha says: 'Monks, there are these three originating causes of action. What three? Greed, hate and delusion. ${ }^{90}$ To free oneself from the entanglements of kamma one must strike at the mentality of the actor. It is the intentions of the actor that are the motor in the continued production of kamma and of continued existence. This is also the case with giving. As regards the laity and their wish for a favourable rebirth, it is not the giving of alms, in itself, that is meritorious and produces fruits, but the intention behind the acts, says the commentator Dhammapāla. ${ }^{91}$ In Jainism, the nature of karma is radically different from that of Buddhism. Still, it is the mentality behind the act that determines its results. For the Jains it is the passions that make the soul receptive to karma. The passions - anger, pride, deception and greed, which became a standard set - work as a kind of glue on the soul to which the substance of karma can stick..$^{92}$ Karmic dust would still be drawn to the soul but would not stick to it were the soul not moistened by the passions. ${ }^{93}$ In the words of the sixthcentury AD author Jinabhadra: 'For it is the intention which is the deciding factor, not the external act. ${ }^{94}$

However, if this was the case, a lay person could theoretically give anything to anyone and earn merit as long as the intention behind the act was right. Why should anyone donate to monks, nuns or Brahmin renouncers when they could earn their merit anywhere else? There were two ways in which the religious specialists could argue that giving to them would be more meritorious than giving to anyone else. First, they could say that there is a quantitative difference between the gift to the religious specialist and any other person. All living beings would theoretically have a place on a scale of merit on which the monk is at the top end. Second, they could say that there is a qualitative difference between giving to a religious specialist and to any other being. The first of these two solutions is based on the assumption that there are certain qualitites in the recipient that determine the efficiency of the donation. We have seen in the section above that this is a 
common view in Buddhist Pāli literature and in the ethnographic data on modern Theravāda Buddhism as well as in Hindu dharmaśāstra literature and medieval Jain texts on giving.

The second of the two solutions is based on a fundamental difference in the religious motivation of the giver. Medhätithi on Manu IV.5 says that the real dāna and pratigraha, giving and accepting, do not include donations made out of compassion..$^{95}$ Gonda has summed up this view thus: 'What is given out of pity or sympathy is not, the same authority observes, conducive to transcendental results, because it does not fulfil the conditions of dāna.' ${ }^{96}$ In Ceylon, Gombrich was told by Buddhist monks that there are two kinds of giving: that which is motivated by respect (gaurava) and that which is motivated by pity (anukampāva). The first variant is exemplified by a gift to the Samgha, the second by a gift to a beggar. ${ }^{97}$ The first, of course, is the better in terms of merit.

Among Jains of modern Jaipur the ideas of intention and the qualities of the recipient are mixed up to make a heterogeneous list of gifts (dan). ${ }^{98}$ There are five types of gifts, the Jains say. These are:

1 the gift of fearlessness;

2 a gift to a worthy recipient;

3 a gift given out of compassion;

4 a gift given out of duty;

5 a gift given to earn fame.

Laidlaw observes that the classificatory principles that underlie this list are divergent. The most important kind of gift, the gift to a worthy recipient, either a Jain renouncer or an idol, is classified according to the recipient, whereas the last three gifts are classified according to the religious motivation of the giver. The principles governing merit for the giver are completely different in the two cases. On the one hand there is the quality of the recipient, on the other hand there is the emphasis on intention. We may note that Hemacandra distinguished between gifts motivated by devotion (bhakti) and compassion (dayaya $){ }^{99}$

In practice, both of these solutions contradict the basic assumption that the intention behind the act determines its fruits. Theoretically, perhaps, the second variant could avoid this contradiction by insisting that the fundamental difference of giving to religious specialists, on the one hand, and giving to any other 
being, on the other, arises only from the difference in motivation. However, in the cases I have encountered the explanation of the difference always involves references to the qualitites of the recipient. The ethic of intention clashes with the theories of merit making.

I have looked at two sets of ideas about action and retribution that are fundamental to the worldview of Indian religions but which are incompatible. This incompatibility surfaces in the act of almsgiving. On the one hand we have the belief that the intention behind an act of giving determines its merit. On the other hand there is the idea that there is a graded or radical difference, in terms of merit, between giving to members of a group of religious specialists, on one side, and to all other beings, on the other. The philosophy that classifies recipients according to merit is an ideology serving the interests of the religious specialists. The aspirations to domination of this class rests on this ideology. If people do not believe in the special merit of giving to the renouncers, the renouncer will not receive alms. This has, of course, been clear to monks and Brahmins and they have worked to keep the ideology alive and gloss over its clash with the ethics of intention. By this I do not mean to say that they themselves have not believed in their ideology.

Applying the theories of Anthony Giddens, we can identify two main ways in which the ideology of the religious specialists gives legitimacy to the social structure of the relevant societies. ${ }^{100}$ First, the ideology of the religious specialists represents its sectional interests as universal ones. By assuming a subordinate position and giving the religious specialist alms the giver really serves his or her own interests according to the teachings of rebirth and merit making. Second, the ideology denies or transmutes the existence of contradiction in their worldviews by splitting the interests of the religious specialist and the householder into two different spheres. The householder should try to make merit by giving alms, whereas merit making is not in the interest of the religious specialist; nor is the monk really interested in the wealth bestowed on him by the householder. The values of monkhood and householdership are incommensurable. Consequently, contradictions do not exist and conflict should not arise. As Dumont observed, the gift is an exchange of material objects with no real value for spiritual goods. ${ }^{101}$ 


\section{Conclusion}

The thesis of this chapter was that there is a common ideology of the gift in the Hindu, Buddhist and Jain traditions and that this common ideology contains two fundamental contradictions. The first contradiction concerns the imagery of gift giving. On the one hand, the gift is seen as a sacrifice. On the other hand, it is seen as an act of charity. The second contradiction concerned the motivation for giving. On the one hand, the qualities of the recipient determine the merit achieved by the gift. On the other hand, it is the intention behind the giving that is important. These two contradictions go together. If the giving is seen as a sacrifice, the qualities of the recipient are naturally the focus of attention. If the gift is charity, the intention of the giver comes to the fore. These contradictions may, theoretically at least, undermine the relationship between renouncer and householder. However, it is interesting to note that these contradictions also can be used to interpret all gift giving in a positive way. In times when there are no worthy recipients the pious layman can earn merit by giving with the right intention, according to Theravāda Buddhist ideology. In the future there will be monks in yellow robes who are of bad conduct (dussīla) and of evil disposition (pāpadhammā) who will be given gifts for the sake of the Samgha, the Buddha says. Even then the gift will be of immeasurable worth. ${ }^{102}$ The Dakkhināvibhaingasutta concludes its exposition of gifts by listing possible combinations of worthy and unworthy donors and recipients. When the worthy donor gives to the unworthy recipient great fruit grows from the act. The giver purifies or hallows the gift (sā dakkhinā dāyakato visujjhati), it is said. When the unworthy donor gives to the worthy recipient great fruit grows from the act. Now, the recipient purifies the gift ( $s \bar{a}$ dakkhinā pațiggāhakato visujjhati). When the unworthy donor gives to the unworthy recipient there is great fruit although the gift is hallowed by neither. We must suppose, then, that it is the act in itself that is meritorious in this case. Finally, when the worthy donor gives to the worthy recipient the donation is, of course, fruitful. The giver always has a choice, it seems, between focusing on the qualitites of the recipient or his or her own right intentions. Giving, then, becomes meritorious a priori. 



\section{NOTES}

\section{INTRODUCTION}

1 Prebish, C. (1994) A Survey of Vinaya Literature, p. 140.

\section{THE HISTORICAL VALUE OF THE KHANDHAKA OF THE VINAYA PIT AKA}

1 Frauwallner, E. (1956) The Earliest Vinaya and the Beginnings of Buddhist Literature.

2 Ibid., p. 1 ff. (Following Frauwallner I use the term Pāli school for the school by which Buddhism was introduced into Ceylon.) For an overview of the literature on Vinaya see Prebish, op. cit.; and Prebish, C. (1979) 'Recent progress in Vinaya studies', In Narain, A. K. (ed.), Studies in Pāli and Buddhism. A Memorial Volume in Honor of Bhikkhu Jagdish Kashyap, p. 302.

3 Ibid., p. 2.

4 Ibid., pp. 1-23.

5 The Dipavamsa (Ch.VIII, p. 53 (translation p. 159)) says that Moggaliputta sent Majjhantika to Gandhāra, Mahādeva to Mahisa Yonakadhammarakkhita to Aparanta, Mahādhammarakkhita to Mahārațha, Mahārakkhita to Yonaka country, Majjhima, Durabhisara, Sahādeva and Mūlakadeva to Himavat, Sona and Uttara to Suvaṇnabhūmi and Mahinda to the island of Lankā. All are said to have preached different discourses and have converted people to Buddhism; Rakkhita is said to have preached the Anamataggiya (i.e. a group of ten suttas in the Samyutta Nikāya). The Mahāvamsa, Ch.XII, p. 94, gives the account of the mission in greater detail than the Dipavamsa. However, the theras who are dispatched by Moggaliputta are more or less the same and the places are the same except that Majjhantika preaches in Kaśmīr as well as in Gandhāra. The Mahâvamsa also says that Rakkhita, whose area of mission is not specified in the Dīpavamsa, is sent to Vanavāsa (southern India?). Moreover, Mahinda's companions to Lankā are specified in the former. 
6 Ibid.,p. 16: 'If we compare with these data the account of the missions in the Singhalese chronicles, we must at once state that the two sources look at the same things from different points of view. Aśsoka speaks of peoples, the missionary accounts speak of countries.'

7 Lamotte says: 'La Chronique singhalaise simplifie les faits à l'extrême en attribuant la conversion générale de l'Inde à l'action d'une poignée de missionnaires mandatés par Moggaliputtatissa et en fixant à cet événement mémorable la date précise de 236 p.N. ... Il va sans dire que l'initiative privée joua son rôle dans le mouvement missionnaire; mais l'effort des individus s'estompe devant la force intrinsèque d'expansion de la Bonne Loi qui, pour se manifester, ne demandait que des circonstances politiques favorables. Celles-ci furent réalisées par la création de l'empire Maurya et la conversion du grand empereur Ásoka. Tous les obstacles étant levés, la Bonne Loi fit en quelque sorte tache d'huile, gagnant de proche en proche presque toutes les régions du continent et s'étendant jusqu 'à Ceylan.' Lamotte, É. (1980) Le Traité de la Grande Vertu de Sagesse, Vol. V, p. 339.

8 v. Frauwallner, op. cit., p. 26.

9 Ibid., p. 27.

10 Ibid., p. 37.

11 Ibid., p. 38.

12 Lamotte, op. cit., p. 196.

13 Ibid., p. 727.

14 Ibid.

15 Gnoli, R. (1977) The Gilgit Manuscript of the Sarighabhedavastu, Part I, p. XVI ff.

16 Ibid., p. XIX.

17 Ibid., p. XX.

18 Panglung, J. L. (1981) Die Erzählstoffe des Mūlasarvāstivāda-Vinaya Analyziert auf Grund der Tibetischen Übersetzung, p. XII.

19 Gnoli, op. cit., p. XX.

20 Lamotte, op. cit., p. 195.

21 Frauwallner, op. cit., p. 50.

22 Waldschmidt, E. (1967). 'Vergleichende Analyse des Catuṣpariṣatsūtra', in Von Ceylon bis Turfan. Schriften zur Geschichte, Literatur, Religion und Kunst des indischen Kulturraumes, pp. 164-202.

23 Ibid., p. 202.

24 Bareau, A. (1963). Recherches sur la biographie du Buddha dans les SūtraPițaka et les VinayaPițaka anciens: de la quête de l'éveil a la conversion de Íāriputra et de Maudgalyāyana, p. 373.

25 Oldenberg, H. (trans.) (1879) The Vinaya Pitaka, Vol. 1, The Mahāvagga, p. XXII.

26 Pachow, W. (1955) A Comparative Study of the Pratimoksa, p. 68.

27 Oldenberg, op. cit., p. XXIII.

28 Ibid.

29 Schlingloff, D. (1963) 'Zur Interpretation des Prātimokṣasūtra', p. 538.

30 Horner, I. B. (trans.) (1951) The Book of the Discipline, Part 4, The Mahāvagga, p. XX. 
31 Frauwallner, op. cit., p. 131.

32 Ibid., p. 155 ff.

33 Ibid., p. 163-4.

$34 v$. Frauwallner, op. cit., Chapter 3, especially p. 54.

35 Ibid.

36 Dīpavamsa VI.1: Dve satāni ca vassāni aț̣hārasa vassāni ca sambuddhe parinibbute abhisitto Piyadassano. Moreover, in Dipavamsa VI.19-20 we are told that the time separating the birth of Mahinda, Ásoka's son from the Parinirvāna of the Buddha was 204 years. Mahāvamsa V.21: Jinanibbā̄nato pacchā pure tassābhisekato sātțhārasam vassasatadvayam evam vijāniyam.

37 v. Bechert, H. (1991) 'Introductory essay', Symposien zur Buddhismusforschung IV, Vol. 1 (ed. H. Bechert), Göttingen, p. 7.

38 Bechert, H. (1982) 'The date of the Buddha reconsidered', Indologica Taurinensia, X (2): 29-37.

39 Ibid., p. 36. Lamotte (op. cit., pp. 13-15) says that the modern historian could opt indifferently for the long or the short chronology. However, Bechert says in the introductory essay (see note 37 ) to the Symposien zur Buddhismusforschung IV (p. 7) that Lamotte has said later that the date of the Buddha should be brought forward. According to Bechert, this view is also expressed in Lamotte's later publications.

40 Bechert, H. (1991) 'The date of the Buddha - an open question of ancient Indian history', Symposien zur Buddhismusforschung IV, Vol. 1 (ed. H. Bechert), Göttingen, pp. 222-36.

41 Gombrich, R. (1992) 'Dating the Buddha: a red herring revealed', Symposien zur Buddhismusforschung IV, Vol. 2 (ed. H. Bechert), Göttingen.

42 Bechert; see note 40 above.

43 Bareau, A. (1991) 'Quelques considérations sur le problème posé par la date du Parinirvana du Buddha', Symposien zur Buddhismusforschung IV, Vol. 1 (ed. H. Bechert), Göttingen, pp. 211-21.

44 von Simson, G. (1991) 'Der zeitgeschichtliche Hintergrund der Entstehung des Buddhismus und seine Bedeutung fur die Datierungsfrage', Symposien zur Buddhismusforschung IV, Vol. 1 (ed. H. Bechert), Göttingen, pp. 90-9.

45 Härtel, H. (1991) 'Archaeological research on ancient Buddhist sites', Symposien zur Buddhismusforschung IV, Vol. 1 (ed. H. Bechert), Göttingen, pp. 61-89.

46 Schmithausen, L. (1992) 'An attempt to estimate the distance in time between Aśsoka and the Buddha in terms of doctrinal history', Symposien zur Buddhismusforschung IV, Vol. 2 (ed. H. Bechert), Göttingen, pp. 110-47.

47 Hirakawa, A. (1991) 'An evaluation of the sources on the date of the Buddha', Symposien zur Buddhismusforschung IV, Vol. 1 (ed. H. Bechert), Göttingen, pp. 252-95.

48 Kulke, H. (1991). 'Some considerations on the significance of Buddha's date for the history of north India', Symposien zur Buddhismusforschung IV, Vol. 1 (ed. H. Bechert), Göttingen, p. 100.

49 Ibid. 
50 Ibid.

51 Bareau, A. (1955) Les premiers Conciles Bouddhiques, p. 88

52 Ibid., p. 88

53 Ibid., p. 89

54 Ibid.

55 Hirakawa, op. cit., p. 269.

56 Hirakawa, in his paper at the Symposien zur Buddhismusforschung $I V$, Vol. 1, discussed the tendency in the oral transmission of Buddhist texts to call every long period of time a century.

57 Bechert (1982), op. cit., p. 36.

58 Franke, O. (1908) 'The Buddhist Councils at Rajagaha and Vesali', pp. 1-80. (Franke says: 'Herewith we are rid of the whole question as to its credibility.' p. 69)

59 Ibid., p. 70.

60 Hofinger, M. (1946) Étude sur le Concile de Vaisali, p. 159

61 Lamotte, op. cit., p. 153.

62 Bareau, op. cit., p. 32.

63 Ibid.

64 Bechert, H. (1995) 'Introductory essay', in Bechert, H. (ed.), When did the Buddha Live? The Controversy on the Dating of the Historical Buddha, pp. 19-20.

65 Oldenberg, op. cit., p. XXXV.

66 Ibid.

67 Ibid., p. XXXVII

68 Ibid., pp. XXII-XXIII.

69 Indeed, if we accept Oldenberg's general view of the documents of history, we should be able to infer the relative lateness of the Skandhaka from the love of details inherent in its precepts. He says: 'This is not the only instance in the history of Buddhism, as of history in general, that the further removed, with respect to time, documents, or pretended documents, are, from the events themselves, the more accurate becomes the knowledge they pretend to contain of them.' (ibid., p. XXII

70 Ibid., pp. XXXVIII-XXXIX

71 Lamotte, op. cit., p. 196

\section{RELIGIOUS MOTIVATION AND THE RELATIONSHIP BETWEEN THE EARLY SAM GHA AND THE LAITY}

1 Wilson, B. R. (1970) Religious Sects. A Sociological Study.

2 Wilson, B. (1963) 'The typology of sects', (trans. J. M. Robertson), Archives de Sociologie de Religion, 16: 49-63.

3 von Simson, G. (1991) 'Der zeitgeschichtliche Hintergrund der Entstehung des Buddhismus und seine Bedeutung fur die Datierungsfrage.' Symposien zur Buddhismusforschung IV, Vol. 1 (ed. H. Bechert), Göttingen, pp. 90-9.

4 Pachow, W. (1955) A Comparative Study of the Pratimoksa, p. 66. 
5 Theragāthā XLV [Psalms of the Early Buddhists. Psalms of the Brethren] (trans. Mrs Rhys Davids, 1913), pp. 49-50.

6 Theragāthā LXXXIV, ibid., p. 81.

7 Mylius, K. (1988) Geschichte der altindischen Literatur, p. 312.

8 Warder, A. K. (1956) 'On the relationship between early Buddhism and other contemporary systems', The Bulletin of the School of Oriental and African Studies, 18: 43-63.

9 Gunawardana, R. A. L. H. (1979) Robe and Plough. Monasticism and Economic Interest in Early Medieval Sri Lanka, pp. 137-39.

10 Carrithers, M. B. (1984) 'They will be Lords upon the Island: Buddhism in Sri Lanka', in Bechert, H. and Gombrich, R. (eds), The World of Buddhism, p. 143.

11 Spiro, M. E. (1982) Buddhism and Society. A Great Tradition and its Burmese Vicissitudes, p. $321 \mathrm{ff}$.

12 Ibid., p. 322.

13 Ibid., p. 325.

14 Wilson (1970), op. cit., pp. 36-48.

15 Basham, A. L. (1981) History and Doctrines of the Āj̄̄vikas

16 In the Mahāparinirvānasūtra 40 the same sect leaders as in the Śāmanyaphalasūtra are the subject of discussion. Here, it is Subhadra who approaches the Buddha and asks why each of these different leaders profess their own, special doctrine. The Buddha explains that only his doctrine leads to the desired goal of Arahantship because it is the only doctrine in which the Aryan eightfold path is found. Outside Buddhism there are no real Śramanas nor real Brahmins; see Waldschmidt, E. (1944) Die Überlieferung vom Lebensende des Buddha. Eine Vergleichende Analyse des Mahāparinirvānasūtra und seiner Textentsprechungen, Göttingen, p. 227 ff.

17 ... mahiddhiko kho mahāsamaṇo mahānubhāvo, ..., na tv eva ca kho arahā yathā ahan ti.

18 Horner, I. B. (trans.) (1951) Mahavāgga of the Vinaya Pitāka (MV) I.20.17.

19 Kassapa of the River is described by Dhammapāla in the commentary to Theragāthā CCIII as carrying on a hermit's life with 300 ascetics on the banks of the river Nerañjarā; hence his name. Here he recalls the fortunate day when the Buddha came to Nerañjarā and he regrets his fire-worship and false religion.

20 Rhys Davids, T. W. (trans.) (1977) Dialogues of the Buddha.

21 Ibid., Vol. II, p. 116-17.

22 Ibid., Vol. IV, p. 40.

23 Geiger, W. (ed.) (1958) The Mahāvamsa, Mahāvamsa XXXIII.9297. The Mahāvamsa itself says that Mahā Tissa was expelled for the offence of having frequented villagers, but both W. Rahula (History of Buddhism in Ceylon. The Anurādhapura Period, p. 83) and R. Gombrich (Theravada Buddhism. A Social History from Ancient Benares to Modern Colombo, p. 158) say that the real reason was probably the threat to the authority and prestige of the monks of the Mahāvihāra. 
24 Manné, J. (1991) 'Categories of sutta in the Pāli Nikāyas and their implications for our appreciation of the Buddhist teaching and literature', Journal of the Pali Text Society, XV: 73.

25 Horner, op. cit., p. X.

26 Ibid., p. XI.

27 The function of this formal act (pakāsaniyakamma) seems to be to free the Samgha of any responsibility as to the words and action of a particular monk.

28 In the following I use the enumeration given in Pachow, op. cit.

29 Gombrich (1988), op. cit., p. 95.

\section{RELIGIOUS MOTIVATION AND THE THEME OF CONVERSION IN BUDDHISM}

1 Richardson, J. T. (1989) 'The psychology of induction: A review and interpretation', In Galanter, M. (ed.), Cults and New Religious Movements, p. $218 \mathrm{ff}$. I have borrowed the term 'the Pauline paradigm' from this article.

2 Ibid., p. 219.

3 Pervin, L. A. (1993) Personality. Theory and Research, p. 12.

4 For a discussion of personal vs. situational determinants of behaviour, see Ross, L. and Nisbett, R. E. (1991) The Person and the Situation. Perspectives of Social Psychology.

5 Pervin, op. cit., p. 13.

6 Wilson, E. O. (1975) Sociobiology. The New Synthesis, p. 4.

7 Wilson, E. O. (1978) On Human Nature, p. 172.

8 Dilthey, W. (1983) Texte zur Kritik der historischen Vernunft, p. 49.

9 Richardson, op. cit., p. 221.

10 Gokhale, B. G. (1965) 'The Early Buddhist Elite', Journal of Indian History, XLII (2): 391-402.

11 Balch, R. W. and Taylor, D. (1978) 'Seekers and saucers: The role of the cultic milieu in joining a UFO cult', in Richardson, J. T. (ed.) Conversion Careers. In and Out of the New Religions, p. 52.

12 Ibid., p. 53

13 Ibid., p. 56.

14 See for instance Warder, A. K. (1956) 'On the relationship between early Buddhism and other contemporary systems', The Bulletin of the School of Oriental and African Studies, 18: 43-63; see especially p. 47.

15 Interestingly, R. L. Fox touches on the same problem in his treatment of the conversion of Constantine. Was the great emperor's conversion a radical break with paganism and the embracing of a new faith or was it a purely pragmatic inclusion of a new and hopefully powerful god into the pantheon in the face of great difficulties? See discussion in Fox, R. L. (1988) Pagans and Christians, p. $609 \mathrm{ff}$.

16 Dutt, N. (1980) The Spread of Buddhism and the Buddhist Schools, p. 26.

17 Lofland, J. (1966) Doomsday Cult, p. 34.

18 Ibid., p. 41. 


\section{SOCIAL PSYCHOLOGY AND THE RELIGIOUS MOTIVATION OF THE EARLY BUDDHISTS}

1 Festinger, L. (1957) A Theory of Cognitive Dissonance.

2 Rothbaum, F., Weisz, J. R. and Snyder, S. S. (1982) 'Changing the world and changing the self: A two-process model of percieved control', Journal of Personality and Social Psychology, 42: 5-37.

3 Berger, P. L. and Luckmann, T. (1991) The Social Construction of Reality, A Treatise in the Sociology of Knowledge, p. 176.

4 Gombrich, R. (1988), op. cit., p. 58.

5 Thapar, R. (1984) From Lineage to State. Social Formations in the Mid-First Millennium BC in the Ganga Valley, p. 99.

6 Festinger, op. cit.

7 Johnston (1935-36), p. 32, note 4.

8 Yinger, M. (1971) The Scientific Study of Religion, p. 32.

9 Gadamer, H.-G. (1965) Wahrheit und Methode, p. 374.

10 James, W. (1961) The Varieties of Religious Experience, p. 122.

11 MacQueen, G. (1988) A Study of the Srāmanyaphalasūtra.

12 Rothbaum et al., op. cit.

13 Ibid., p. 24.

14 Ibid., p. 26.

15 Dīgha Nikāya (trans. T. W. Rhys Davids, 1977) 1:156. Note that I have changed the translations of ceto-vimutti and pañ $\tilde{a}$-vimutti to conform to the translations by Gombrich in How Buddhism Began, referred to in note 17 below.

16 Dīgha Nikāya (op. cit.) 1: 167.

17 Gombrich, R. (1996) How Buddhism Began. Chapter 4 (pp. 96-134) of that book is a discussion of how the two concepts, ceto-vimutti and pañ $\tilde{a}$-vimutti, came to mean different things in the early development of Buddhist doctrine.

18 Ibid.

19 Penner, H. H. and Yonan E. A. (1972) 'Is a science of religion possible?', The Journal of Religion, 52: 124 and 130.

20 Argyle, M. and Beit-Hallami, B. (1997) The Psychology of Religious Behavior, Belief and Experience, London: Routledge and Kegan Paul, p. 230.

\section{RELIGIOUS MOTIVATION AND THE ROLE OF FEAR}

1 Śāntideva [1996] The Bodhicaryāvatāra (trans. K. Crosby and A. Skilton), p. 140.

2 See, for instance, Morris, B. (1994) Anthropological Studies of Religion, p. $141 \mathrm{ff}$.

3 Weerasinghe, H. (1997) 'Fear: A Buddhist interpretation', in Dhammajoti, K. L., Tilakaratne, A. and Abhayawansa, K. (eds), Recent Researches in Buddhist Studies. Essays in Honour of Professor Y. Karunadasa, pp. 612-29.

4 For references to this theme in śaivism see Doniger O'Flaherty, W. (1973) Asceticism and Eroticism in the Mythology of Siva, p. 236. 
5 Masson, J. L. and Patwardhan, M. V. (1970) Aesthetic Rapture. The Rasadhaya of the Nātyásāstra, Vol. 1, p. 54

6 Dhammapada 212-216.

7 Skilling, P. (ed.) (1994) Mahāsūtras: Great Discourses of the Buddha, Vol. 1, p. 305.

8 Bodhi, B. (1995) Majjhima Nikāya I.20-21, The Middle Length Discourses of the Buddha (trans. B. Nānamamoli), p. 104.

9 Sutta-Nipāta 964.

10 Añguttara Nikāya II.121

11 Dīgha Nikāya III, p. 182; Rhys Davids, T. W. and Rhys Davids, C.A.F. (eds) (1921) Dialogues of the Buddha, Part III, p. 174.

12 Lamotte, É. (1980) Le Traité de la Grande Vertu de Sagesse, Vol. V, p. 2249.

13 Brekke, T. (1998) 'Contradiction and the merit of giving in Indian religions', Numen, International Review for the History of Religion, 45: $287-320$.

14 Ling, T. O. (1962) Buddhism and the Mythology of Evil, p. 156.

15 Dhammpada 317 (trans. Radhakrishnan S.), in Radhakrishnan, S. (1992). The Dhammapada, p. 158.

16 Dīgha Nikāya III.148; Rhys Davids, T.W. and Rhys Davids, C.A.F. (1921) Dialogues of the Buddha, Part III, p. 141.

17 Mahāvamsa I.23-27

18 Samyutta Nikāya III, pp. 84-6; Añguttara Nikāya II, pp. 33-4.

19 Conze, E. (trans.) (1990) The Large Sutra on Perfect Wisdom, pp. 320-1.

20 Williams, R. (1983) Jain Yoga. A Survey of the Mediaeval śrāvakācāras, p. 43. The word sainka, however, is mostly taken to mean doubt, and the negative nih́sarika may sometimes have the meaning of freedom from doubt besides freedom from fear.

21 Jaini, P. (1990) The Jaina Path of Purification, p. 120.

22 Williams, R. (1991) Jaina Yoga, p. 42.

23 This missionary strategy is essentially similar to those used by many modern sects. For instance, social scientists have described how religious groups in America induce psychological distress in potential converts. When the convert is brought closer to the group he or she will feel a relief that will create strong emotional bonds and make it difficult to break away. See, for instance, Galanter, M. (1989) Cults. Faith, Healing and Coercion, pp. 87-97; Lofland, J. (1966) Doomsday Cult; Balch, R. W. and Taylor, D. (1978) 'Seekers and saucers: The role of the cultic milieu in joining a UFO cult', in Richardson, J. T (ed.), Conversion Careers. In and Out of the New Religions.

24 Milindapañho, p. 145 ff; Rhys Davids, T. W. (ed.) (1925) The Questions of King Milinda, p. 206 ff.

25 Samyutta Nikāya III.83.

26 Theragāthā 189-90.

27 Samyutta Nikāya I.106.

28 Buddhavamsa, p. 64.

29 The Clarifier of the Sweet Meaning, commentary on Buddhadatta Thera (1978) Chronicle of Buddhas (trans. I. B. Horner), p. 386. 
30 Poussin, L. de La Vallée (Trans.) (1971-80) L'Abhidharmakósa de Vasubandhu, 6 vols. Brussels: Institute des hautes Etudes Chinoises (English trans. L. M. Pruden), pp. 1141-2.

31 Ibid.

32 Rhys Davids, C. A. F. (ed.) (1921) The Visuddhimagga of Buddhaghosa, Vol. 2, p. 512. Ñyāṇamoli, B. (trans.) (1964) The Path of Purification, pp. 586.

33 Samyutta Nikāya I.154.

34 İ́ ádidásopaniṣadạ [1978] Ten Principal Upanshads with Śāikarabhāṣa, p. 367; Olivelle, P. (trans.) (1996) Upanișads, p. 101.

35 See, for instance, Chāndogya Upaniṣad 4.15.1, Bṛhadāranyaka Upanisad 4.3.21.

36 İs àdidásopanișadaḥ, op. cit., p. 574; Olivelle, op. cit., p. 169.

37 Olivelle, op. cit., pp. 285-6.

38 Ibid., pp. 232-3.

39 Translation in Olivelle, op. cit., p. 188.

40 The explication of Śankara's views on fear contained in his commentary on the Taittirizya Upanișad is based on the text in İ́sàdidásopanișadạ, op. cit., pp. 302-4.

41 Olivelle, op. cit., p. 13.

42 İ́ādidásopanișadạ, op. cit., p. 648.

43 General similarities and interbreedings between Vedānta and Buddhism has been treated in some detail by several authors. See, for instance, Jennings, J. G. (1947) The Vedāntic Buddhism of the Buddha.

44 Śāntideva, op. cit., p. 67.

45 Williams, P. (1994) Mahāyāna Buddhism, p. 61.

46 Śāntideva, op. cit., p. 34.

47 Ibid., p. 120.

48 Śāntideva [1957] Ś ikṣā Samuccaya (ed. C. Bendall), p. 198.

49 For an example of how the Madhyamaka sought to refute the idea of the Self in the Vedānta see Qvarnström, O. (1989) Hindu Philosophy in Buddhist Perspective.

50 Sutta-Nipāta 207.

51 Sutta-Nipāta 107.

52 Sutta-Nipāta 572.

53 t̄̄vrasamvegānāmāsannah; Kapila, M. (1940) Patanjala Darshana of the System of Yoga Philosophy (ed. P. J.Vidyasagara, with the commentary of Vyasa and Vachaspati Mishra), p. 25; also translated in Woods, J. H. (1914) The Yoga System of Patañjali.

54 Jayawickrama, N. A. (ed.) (1971) Thüpavamsa. The Chronicle of the Thüpa and the Thüpavamsa, p. 164.

55 Dīgha Nikāya III, p. 214; Rhys Davids, T. W. and Rhys Davids, C. A. F. (1921) Dialogues of the Buddha, Part III, p. 206.

56 Samyutta Nikāya I, p. 197 ff.; Rhys Davids, C. A. F. (1950) The Book of the Kindred Sayings, Part I, p. $250 \mathrm{ff}$.

57 Samyutta Nikāya V, p. 130; Woodward, F. L. (1956) The Kindred Sayings, Part V, p. 111.

58 Woodward's (see note 57) translation has left out vipubbakasaññ $\bar{a}$, the festering corpse. 
59 Añguttara Nikāya II, p. 17; Woodward, F. L. (1952) The Book of the Gradual Sayings, Vol. II, pp. 16-17.

60 Bodhi, B. (ed.) A Comprehensive Manual of Abhidhamma. The Abhidhammattha Sangaha of Ācariya Anuruddha, pp. $329 \mathrm{ff}$.

61 Itivuttaka, p. 93; Woodward, F. L. (1935) The Minor Anthologies of the Pali Canon, Part II, p. 182.

62 Itivuttaka, pp. 29-30; Woodward (1935), op. cit., p. 137.

63 Samyutta Nikāya III, pp. 84-6 and Añguttara Nikāya II, pp. 33-4.

64 The basically identical accounts in the Samyutta Nikāya and the Anguttara Nikāya differ in how they sum up the contents of this Dhamma. The Ariguttara Nikāya talks about the Dhamma that teaches the constitution, the origin, the ending and the way to end the existing person or individuality (sakkāya) whereas the Samyutta Nikāya describes the Dhamma as the teaching of the nature of body (rüpa), feeling (vedanā), perception (sañ $\tilde{a})$, activities or coefficients of

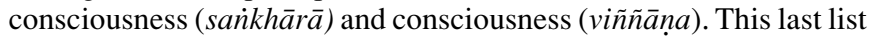
is, of course, a standard enumeration of the five khandhas and it seems reasonable to take the sakkāya of the Ariguttara Nikāya too as referring to the khandhas.

65 acirād dhi manuṣyāṇạm mrgasamjjñā (bhaviṣya)ti tasmāt sarvair àyuṣmadbhir udvignaih samvegam āpannaih tasyānuttaradaś abaladharadharmarājacakravartinah paurān sucaritakarmavipā kanirjātasya mrṣāvādapaiś unyapāruș yābaddhapralāpavivarjitasya satyānuvartivaca(nasya anvardha)māsāvavādānúsāsanaṃ śrotavyam, von Simson, G. (1986) Prātimokșasūtra der Sarvāstivādins, p. 2.

66 Rhys Davids, C. A. F. (1920) The Visuddhimagga of Buddhaghosa, Vol. 1, p. 135; Ñyānamoli, The Path of Purification, op. cit., pp. 140-1.

67 Visuddhimagga $645 \mathrm{ff}$.

68 Visuddhimagga 651.

69 Śāntideva, The Bodhicaryāvatāra, op. cit., pp. 68-9.

70 Ibid., p. 36.

71 Ibid., p. 51.

72 Ibid., p. 18; certain verses have been left out here.

73 Śāntideva, Ś ikṣā Samuccaya, op. cit., p. 198; translation in Sāntideva [1990] Ś ikṣā Samuccaya (trans. C. Bendall and W. H. D. Rouse) (1st edn 1922), p. 192.

74 Ibid.

75 Añguttara Nikāya, Vol. III p. $100 \mathrm{ff}$.

76 Añguttara Nikāya, Vol. III (trans E. M. Hare), p. 81.

77 Aniguttara Nikāya, Vol. III, p. 104.; for a study of Buddhism's relationship to the dangers of nature see Schmithausen, L. (1997) Maitri and Magic: Aspects of the Buddhist Attitude Toward the Dangerous in Nature.

78 Añguttara Nikāya, Vol. III, p. $100 \mathrm{ff}$.

79 Gombrich, R. (1996) How Buddhism Began. The Conditioned Genesis of the Early Teachings, p. 17.

80 MacQueen, G. (1988) A Study of the Śrāmanyaphalasūtra. 
81 Ibid., p. 261.

82 Mahāvamsa I.23-27; translation in Geiger, W. (trans.) (1934) The Mahāvamsa, pp. 3-4.

83 Wijayaratna, M. (1990) Buddhist Monastic Life (trans. C. Grangier and S. Collins), p. 130.

84 Dutt, N. (1980) The Spread of Buddhism and the Buddhist Schools, p. $22 \mathrm{ff}$.

85 Wijayaratna, op. cit., p. 130.

86 Lamotte, É. (1988) History of Indian Buddhism (English trans. S. Webb-Boin), p. 307.

87 Ibid., p. 310.

88 A similar point has been brought out in the works of René Girard, who says that a typical feature of myths is that they tend to undergo revisions through time whereby references to violence are cut away bit by bit until one is left with stories that seem peaceful if slightly half-baked, as in the myth of the death of Baldr or Zeus in Scandinavian or Greek mythology respectively; see Girard, R. (1989) The Scapegoat, p. 166 ff.

89 These examples are taken from Ejima, Y. (ed.) (1985) Index to the Saddharmapundarīkasūtra, Vol. 1, p. 76.

90 Hārītasmrti, 6.5, in Dutt, M. N. (trans.) (1978) The Dharam Shastra. Hindu Religious Codes, Vol. 1.

91 Sprockhoff, J. D. (1994) 'Zur 'Weihe' des Asketen', Wiener Zeitschrift für die Kunde Südasiens, 38: 61-83; see especially pp. 63-3 and pp. 77-80. See also Schmithausen, L., op. cit., p. 32, note 66.

92 Hoelter, J. W. and Epley, R. J. (1979) 'Religious correlates of fear of death', Journal for the Scientific Study of Religion, 18: 404-11.

93 Ibid., p. 410.

94 Thorson, J. A. and Powell, F. C. (1990) 'Meanings of death and intrinsic religiosity', Journal of Clinical Psychology, 46 (4): 379_ 91.

95 Ibid., p. 386.

96 Osarchuk, M. and Tatz, S. J. (1973) 'Effect of induced fear of death on belief in afterlife', Journal of Personality and Social Psychology 27: $256-60$.

97 See, for instance, Hannay, A. (1991) Kierkegaard, p. 202; Gardiner, P. (1988) Kierkegaard, p. 111.

\section{RELIGIOUS MOTIVATION AND THE MERIT OF GIVING}

1 Manu 4.87-91; Doniger, W. and Smith, B. K. (1991) The Laws of Мапи, p. 82.

2 Mauss, M. (1993) The Gift.

3 Heesterman, J. C. (1963) 'Brahmin, ritual and renouncer', Wiener Zeitschrift für die Kunde Süd- und Ostasiens, 7: 3 and 14-16.

4 Parry, J. J. (1994) Death in Banaras, p. 123; see also Parry, J. (1986) "The gift, the Indian gift and the "Indian Gift",

5 Raheja, G. G. (1988). The Poison in the Gift. 
6 Williams, R. (1983) Jaina Yoga. A Survey of the Mediaeval śrāvakācāras, p. 150. For a different sixfold classification belonging to the Hindu tradition see Kane, P. V. (1974) History of Dharmásāstra, Vol. 2, Part II, p. 843.

7 See Chapters 2 and 4 of Schopen, G. (1997) Bones, Stones and Buddhist Monks. Collected Papers on the Archaeology, Epigraphy, and Texts of Monastic Buddhism in India, Honolulu: University of Hawai'i Press.

8 The term going forth is a translation of pabbaja. It is a technical term which refers to the first of the two stages in the admission to the Samgha, the second stage being the full ordination, upasampadā. Pabbajā (or pravrajyā in Sanskrit) can be used in a more general sense referring to the adoption of the ascetic life.

9 Spiro, M. E. (1984) Buddhism and Society, p. 415

10 Williams, op. cit., p. 153.

11 Ibid.

12 Paranavitana, S. (1970) Archaeological Survey of Ceylon. Inscriptions of Ceylon, Vol. 1, Ceylon.

13 Ñāṇamoli, B. and Bodhi, B. (1995) The Middle Length Discourses of the Buddha. A New Translation of the Majjhima Nikāya, pp. 5889; Trenckner, V. (ed.) (1948) Majjhima Nikāya, Vol. 1, p. 483. The Kathâvatthu agrees that it is impossible to attain salvation as a householder; see Aung, S. Z. and Rhys Davids, M. (1979) Points of Controversy, pp. 157-8.

14 Although, according to the Cullavagga X, the Buddha initially refused when his foster mother, Pajāpatī, asked him to let women be allowed to go forth, several passages from other texts testify that women were seen as capable of attaining Nirvāna. For instance, the nun Samghamittā achieved salvation at the age of 59 (Mahāvamsa, XX.48 ff.). Saṃghamittā was the daughter of Aśsoka and the sister of Mahinda. She went to Ceylon after her brother, bringing a branch of the Bodhi tree, in order to establish the order of nuns on the island.

15 Fleet, J. F. (1888) Corpus Inscriptionum Indicarum, Vol. III, Inscriptions of the Early Gupta Kings and their Successors, p. $93 \mathrm{ff}$.

16 Ibid., pp. 179 and 189.

17 Shri Acharya Kunda Kunda (1990) Samayasara (translation and commentaries by J. L. Jain, p. 92.

18 Reynell, J. (1985) 'Renunciation and ostentation', Cambridge Anthropology, 9 (3): 20-33.

19 Ibid.

20 Norman, K. R. (1991) 'The role of the layman according to the Jain canon', in Carrithers, M and Humphrey, C. (eds), The Assembly of Listeners, pp. 31-9.

21 Williams, op. cit., p. $163 \mathrm{ff}$.

22 Ibid.

23 Ibid., p. 153.

24 Cort, J. E. (1991) 'Two ideals of the śvetāmbar Mūrtipūjak Jain layman', Journal of Indian Philosophy, 19: 394-5 and footnotes 11 and 14.

25 Ibid., pp. 391-420. 
26 Gehman, H. S. (trans.) (1993) Petavatthu: Stories of the Departed. The Minor Anthologies of the Pali Canon, p. 36 (second part).

27 Мапи 4.240, Doniger and Smith, op. cit., p. 96.

28 mātāpittror ātmanaś cha punyābhiṿ̂rddhaye; Fleet, op. cit., pp. 93112.

29 Ibid., pp. 158-61.

30 A large number of the records of grants of land quote a particular verse from the Mahābhärata to explain the significance of their gift. Typically they say: 'And it has been said by Vyāsa, the arranger of the Vedas - The giver of land abides in heaven for sixty thousand years; (but) the confiscator (of a grant), and he who assents (to an act of confiscation), shall dwell for the same number of years in hell! $\mathrm{O}$ Yudhiștira, best of kings, carefully preserve land that has previously been given to the twice-born; (verily) the preservation (of a grant) or more meritorious than making a grant! The earth has been enjoyed by many kings, commencing with Sagara; whosoever at any time possesses the earth, to him belongs, at that time, the reward (of this grant that is now made, if he continue it)!'

31 Quoted in Jaini, P. S. (1980). 'Karma and the problem of rebirth in Jainism', in Doniger O'Flaherty, W. (ed.), Karma and the Problem of Rebirth in Classical Indian Traditions, p. 235.

32 Ibid.

33 Bechert, H. (1992) 'Buddha-field and transfer of merit in a Theravāda source', Indo-Iranian Journal, 35: 95-108; whether or not Theravāda Buddhism borrowed the idea of transference of merit from Mahāyāna, Bechert is right in reminding us that a monk may have followed Mahāyāna teachings while belonging to a Hīnayāna school in terms of Vinaya. It is monastic discipline, not philosophy, that creates the important dividing lines between different Buddhist communities. However, that Mahāyānism was suppressed in Ceylon later, is clear from the accounts of the Mahāvamsa.

34 Gombrich, R. (1972) “ 'Merit transference' in Sinhalese Buddhism: A case study of the interaction between doctrine and practice', History of Religions, 11: 203-19.

35 anujānāmi bhikkhave imehi ațthah' angehi samannāgatassa upāsakassa pattạ̣ ukkujjitum.

36 Mauss, op. cit., p. 59.

37 Laidlaw, J. (1995) Riches and Renunciation, p. 316.

38 Dakkhin̄à ti pana paralokam saddahitvā dātabbadānam vuccati; Rhys Davids, C. A. F. (1920) The Visuddhimagga of Buddhaghosa, Vol. 1, p. 220 .

39 ... anuttarạ̣ puñ̃̃a-kkhettam lokassāti; Dīghā Nikāya XXIV.1.6, in Estlin Carpenter, J. (ed.) (1947) The Dīgha Nikāya, Oxford, 1947. Translation from Rhys Davids, T. W. (trans.) (1977) Dialogues of the Buddha, Part III, p. 11.

40 Dīgha Nikāya XXXIII.1.11.XIV (translation) Vol. 4, p. 219.

41 Gehman, op. cit., pp. 2-3 (second part).

42 Rhys Davids, C. A. F. (1920) The Visuddhimagga of Buddhaghosa, Vol. 1, p. 220; German translation in Visuddhi-Magga oder der Weg zum Reinheit, übersetzt von Nyanatiloka, p. 258. 
43 Williams, op. cit., p. 165.

44 Trenckner, V. (ed.) (1948) Dakkhiṇ̄̄ibhañgasutta, Majjhima Nikāya, p. 253 ff.; translation from Chalmers, Lord (1927) Further Dialogues of the Buddha, p. $299 \mathrm{ff}$.

45 Spiro, op. cit., p. 109.

46 Williams, op. cit., p. 152.

47 Mапи 7.85-6, Doniger and Smith, op. cit.

48 Yajñavalkyasmrti 1.200-202.

49 Мапи 7.135.

50 Мапи 9.245.

51 Мапи 3.142.

52 Мапи $3.150 \mathrm{ff}$.

53 Anúsāsanaparvan 37.6.

54 Anúsāsanaparvan 37.8-9.

55 ... arogyamahimsayā; Anúsāsanaparvan 57.19.

56 Мапи, 4.187-8, Doniger and Smith, op. cit., p. 91.

57 Spiro, op. cit., pp. 106-7.

58 Trautmann, T. R. (1981) Dravidian Kinship, p. 285.

59 Oldenberg, H. (1894). Die Religion des Veda, p. 377.

60 Gonda, J. (1966) Loka - World and Heaven in the Veda, p. 130

61 Ibid., pp. 125-6.

62 Mundaka Upanișad, in Olivelle, P. (trans.) (1996) Upaniṣads, p. 270.

63 Kaușītaki Upanișad 2.5, ibid., p. 208.

64 agnimātmani saṃsthāpya dvija pravrajito bhavet; Dutt, N. M. (ed.) (1978) Samvartasmrti 102, p. 344.

65 Rhys Davids (1977) Küțadanta Sutta, Dīgha Nikāya 1.127.

66 Manu 7.84, Doniger and Smith, op. cit.

67 Mauss, op. cit., p. 59.

68 Translated in Dutt, Samvartasmrti, op. cit., p. 325; the English has been slightly shortened by me.

69 Samvartasmrti 91; ibid., p. 343.

70 Williams, op. cit., p. 157.

71 Ibid.

72 Ganapati Sastri, M. T. (ed.) (1982) Yajñavalkyasmrti (with commentary of Bālakrīda of Viśvarūpāchārya), p. 142.

73 Hārītasmīti 6.5 .

74 Brhaspatismrti 71.

75 Dakșasmrti 3.8-14; translated in Dutt (1978), op. cit., p. 443.

76 Мапи 4.227.

77 Kane (1974), Vol. 2, Part I, p. 116.

78 Anús̄āsanaparvan 60.9 .

79 The Āpastamba Dharmasūtra 2.3.7.1-10, in Bühler, G. (trans.) (1965) The Sacred Laws of the Äryas, Part II, pp. 116-17.

80 Ibid.

81 Vasișta Dharmasūtra 30.2, in Bühler, op. cit., Part I, p. 138.

82 Ibid.

83 Мапи 3.98.

84 Kane, op. cit., Vol. 2, Part I, p. 118 and Vol.2, Part II, p. 840

85 Hultzsch, E. (1925) Corpus Inscriptionum Indicarum, Vol. 1, Inscriptions of Ásoka, pp. 33-4. 
86 See, for instance, the eighth, ninth and eleventh rock inscriptions of Kalsi; ibid., p. 37-8.

87 Fleet, op. cit., pp. 180 and 190.

88 Bhagavadgītā 17.20-22.

89 Bhagavadgìtā 3.11-12.

90 Ariguttara Nikāya 1.134 (translation), p. 117.

91 Masefield, P. (1980) Dhammapāla. Elucidation of the Intrinsic Meaning So Named the Commentary on the Peta-Stories (translated U Ba Kyaw), p. 10.

92 Dundas, P. (1992) The Jains, p. 84; Schubring, W. (1962) The Doctrine of the Jainas, p. 174.

93 Jaini, P. S. (1974) The Jaina Path of Purification, p. 112.

94 Quoted in Laidlaw, op. cit., p. 193.

95 Kane, op. cit., Vol. 2, Part 1, p. 116.

96 Gonda, J. (1975) " "Gifts" and "giving" in the Rgveda', in Selected Studies, Vol. 4, p. 134.

97 Gombrich, R. F. (1971) Precept and Practice. Traditional Buddhism in the Rural Highlands of Ceylon, pp. 248-9.

98 See Laidlaw, op. cit., p. 296 ff.

99 Cort, op. cit., pp. 394 and 395.

100 Giddens, A. (1979) Central Problems in Social Theory, p. 193 ff.

101 Dumont, L. (1980) Homo Hierarchicus, p. 117.

102 Trenckner, op. cit., p. 253 ff.; translation from Chalmers, op. cit., Further Dialogues of the Buddha, p. 299 ff. 



\section{BIBLIOGRAPHY}

Andersen, D. and Smith, H. (eds) (1948) Sutta-Nipāta, London: Pali Text Society.

Argyle, M. and Beit-Hallami, B. (1997) The Psychology of Religious Behavior, Belief and Experience, London: Routledge and Kegan Paul.

Aung, S. Z. and Rhys Davids, M. (1979) Points of Controversy, London: Pali Text Society.

Balch, R. W. and Taylor, D. (1978) 'Seekers and saucers: the role of the cultic milieu in joining a UFO cult', in Richardson J. T. (ed.), Conversion Careers. In and Out of the New Religions, Beverly Hills, CA: Sage.

Bareau, A. (1955) Les premiers Conciles Bouddhiques, Paris: Presses Universitaires.

Bareau, A. (1963). Recherches sur la biographie du Buddha dans les Sūtra Pițaka et les Vinaya Pitaka anciens: de la quête de l'éveil a la conversion de Íáriputra et de Maudgalyāyana, Paris: Presses Universitaires.

Bareau, A. (1991) 'Quelques considérations sur le problème posé par la date du Parinirvana du Buddha', Symposien zur Buddhismusforschung $I V$, Vol. 1 (ed. H. Bechert), Göttingen: Vandenhoeck \& Ruprecht.

Basham, A. L. (1981) History and Doctrines of the Ājīvikas, Delhi: Motilal Banarsidass.

Bechert, H. (1982) 'The date of the Buddha reconsidered', Indologica Taurinensia, X (2): 29-37.

Bechert, H. (1991) 'Introductory essay', Symposien zur Buddhismusforschung IV, Vol. 1 (ed. H. Bechert), Göttingen: Vandenhoeck \& Ruprecht.

Bechert, H. (1991) 'The date of the Buddha - an open question of ancient Indian history', Symposien zur Buddhismusforschung IV, Vol. 1 (ed. H. Bechert), Göttingen: Vandenhoeck \& Ruprecht.

Bechert, H. (1992) 'Buddha-field and transfer of merit in a Theravāda source', Indo-Iranian Journal, 35: 95-108 
Bechert, H. (1995) 'Introductory essay', in Bechert, H. (ed.), When did the Buddha Live? The Controversy on the Dating of the Historical Buddha, Delhi: Sri satguru Publications.

Berger, P. L. and Luckman, T. (1991) The Social Construction of Reality, A Treatise in the Sociology of Knowledge, Harmondsworth, UK: Penguin.

Bodhi, B. (ed.) (1993) A Comprehensive Manual of Abhidhamma. The Abhidhammattha Sangaha of Ācariya Anuruddha, Kandy: Buddhist Publication Society.

Brekke, T. (1997) 'The early Samgha and the laity', Journal of the International Association of Buddhist Studies, 20 (2): 7-33.

Brekke, T. (1998) 'Contradiction and the merit of giving in Indian religions', Numen, International Review for the History of Religion, 45: 287-320.

Brekke, T. (1998) 'The Skandhaka of the Vinaya Pitaka and its historical value', Wiener Zeitschrift für die Kunde Südasiens und Archiv für Indische Philosophie, XLII: 23-40.

Brekke, T. (1999) 'The role of fear in Indian religions with special reference to Buddhism', Journal of Indian Philosophy, 27: 439-67.

Brekke, T. (1999) 'The religious motivation of the early Buddhists', Journal of the American Academy of Religion, 67 (4): 849-66.

Brekke, T. (forthcoming) 'Conversion in Buddhism?', in Robinson, R. and Clarkes, S. (eds), Conversion in Indian Religions, Delhi: Oxford University Press.

Bühler, G. (trans.) (1965) The Sacred Laws of the Äryas, Delhi.

Carrithers, M. B. (1984) 'They will be Lords upon the Island: Buddhism in Sri Lanka', in Bechert, H. and Gombrich, R. (eds), The World of Buddhism, London: Thames and Hudson.

Carrithers, M. and Humphrey, Caroline (eds.) (1991) The Assembly of Listeners. Jains in Society, Cambridge: Cambridge University Press.

Chalmers, Lord (1927) Further Dialogues of the Buddha, London: Pali Text Society

Conze, E. (1990) The Large Sutra on Perfect Wisdom, Delhi: Sagar Publications.

Cort, J. E. (1991) 'Two ideals of the śvetāmbar Mūrtipūjak Jain layman', Journal of Indian Philosophy, 19: 391-420.

Dandekar, R. M. (1966) Anúsāsanaparvan of the Mahābhārata, Poona.

Dilthey, W. (1983) Texte zur Kritik der historischen Vernunft, Göttingen.

Doniger O'Flaherty, W. (1973) Asceticism and Eroticism in the Mythology of Śiva, London: Oxford University Press.

Doniger, W. and Smith, B. K. (eds) (1991) The Laws of Manu, Harmondsworth, UK: Penguin. 
Dumont, L. (ed.) (1980) Homo Hierarchicus (trans. M. Sainsbury, L. Dumont and B. Gulati), complete rev. English edn, Chicago: The University of Chicago Press.

Dundas, P. (1987-8) 'The tenth wonder: Domestication and reform in Medieval śvetāmbara Jainism', Indologica Taurinensia, XIV: 182-94.

Dundas, P. (1992) The Jains, London: Routledge.

Dutt, M. N. (trans.) (1978) The Dharam Shastra. Hindu Religious Codes, Vol. 1, Delhi: Cosmo Publications.

Dutt, M. N. (ed.) (1978) Āpastamba Dharmásāstra, New Delhi.

Dutt, M. N. (ed.) (1978) Gautama Dharmásāstra, New Delhi.

Dutt, M. N. (ed.) (1978) Mānava Dharmásāstra, New Delhi.

Dutt, M. N. (ed.) (1978) Yājñavalkya Dharmás̄āstra, New Delhi.

Dutt, N. (1980) The Spread of Buddhism and the Buddhist Schools, New Delhi.

Dutta, M. N. (1978-9) The Dharam Shastra, Hindu Religious Codes, six vols, New Delhi.

Ejima, Y. (1985) Index to the Saddharmapundarīkasūtra, Tokyo.

Festinger, L. (1957) A Theory of Cognitive Dissonance, Stanford, CA: Stanford University Press.

Fleet, J. F. (1888) Corpus Inscriptionum Indicarum, Vol. III, Inscriptions of the Early Gupta Kings and their Successors, Calcutta.

Fox, R. L. (1988) Pagans and Christians, San Francisco: University of California Press.

Franke, O. (1908) 'The Buddhist Councils at Rajagaha and Vesali', Journal of the Pali Text Society, VI.

Frauwallner, E. (1956) The Earliest Vinaya and the Beginnings of Buddhist Literature, Rome: Instituto Italiano per il Medio ed Estremo Oriente.

Freer, L. (ed.) (1960) Samyutta Nikāya, London.

Gadamer, H.-G. (1965) Wahrheit und Methode, Tübingen: JCB Mohr.

Galanter, M. (1989) Cults, Faith, Healing and Coercion, Oxford: Oxford University Press.

Ganapati Sastri, M. T. (ed.) (1982) Yajñavalkyasmrti, with commentary of Bālakrīda of Viśsvarūpāchārya, New Delhi.

Gardiner, P. (1988) Kierkegaard, Oxford and New York: Oxford University Press.

Gehman, H. S. (trans.) (1993) Petavatthu: Stories of the Departed. The Minor Anthologies of the Pali Canon, Oxford.

Geiger, W. (trans.) (1934) Mahāvamsa, London.

Geiger, W. (ed.) (1958) Mahāvaṃsa, London.

Giddens, A. (1979) Central Problems in Social Theory, Cambridge: Cambridge University Press.

Girard, R. (1989) The Scapegoat. Baltimore, MD: Johns Hopkins University Press. 
Gnoli, R. (1977) The Gilgit Manuscript of the Sarghabhedavastu, Part I, Rome: Instituto Italiano per il Medio ed Estremo Oriente.

Gokhale, B. G. (1965) 'The early Buddhist elite', Journal of Indian History 42 (2): 391-402.

Gombrich, R. F. (1971) Precept and Practice. Traditional Buddhism in the Rural Highlands of Ceylon, Oxford: Oxford University Press.

Gombrich, R. F. (1972) 'Merit transference' in Sinhalese Buddhism: A case study of the interaction between doctrine and practice', History of Religions, 11: 203-19.

Gombrich, R. F. (1988) Theravada Buddhism. A Social History from Ancient Benares to Modern Colombo, London: Routledge.

Gombrich, R. (1992) 'Dating the Buddha: a red herring revealed', Symposien zur Buddhismusforschung IV, Vol. 2 (ed. H. Bechert), Gottingen: Vandenhoeck \& Ruprecht.

Gombrich, R. F. (1996) How Buddhism Began. The Conditioned Genesis of the Early Teachings, London: Athlone.

Gonda, J. (1975) “ "Gifts” and "Giving” in the Rgveda', Selected Studies, Vol. 4, Leiden.

Gunawardana, R. A. L. H. (1979) Robe and Plough. Monasticism and Economic Interest in Early Medieval Sri Lanka, Tucson, AZ: University of Arizona Press, pp. 137-9.

Hannay, A. (1991) Kierkegaard, London: Routledge.

Hardy, E. (ed.) (1958) Añguttara Nikāya, Vol. III, London: Pali Text Society.

Hare, E. M. (trans.) (1952) Añguttara Nikāya, Vol. III, London: Pali Text Society.

Hare, E. M. (trans.) (date) Woven Cadences of Early Buddhists [SuttaNipāta], London: Pali Text Society.

Härtel, H. (1991) 'Archaeological research on ancient Buddhist sites', Symposien zur Buddhismusforschung IV, Vol. 1 (ed. H. Bechert), Gottingen: Vandenhoeck \& Ruprecht.

Heesterman, J. C. (1963) 'Brahmin, ritual and renouncer', Wiener Zeitschrift für die Kunde Süd-und Ostasiens, 7.

Hirakawa, A. (1991) 'An evaluation of the sources on the date of the Buddha', Symposien zur Buddhismusforschung IV, Vol. 1 (ed. H. Bechert), Gottingen: Vandenhoeck \& Ruprecht.

Hoelter, J. W. and Epley, R. J. (1979) 'Religious correlates of fear of death', Journal for the Scientific Study of Religion, 18: 404-11.

Hofinger, M. (1946) Étude sur le Concile de Vaisali, Louvain la Neuve.

Horner, I. B. (trans.) (1942-66) Vinaya Pitakam, London: Pali Text Society. Horner, I. B. (trans.) (1957) Majjhima Nikāya, London: Pali Text Society. Horner, I. B. (trans.) (1978) The Clarifier of the Sweet Meaning, commentary on the Chronicle of Buddhas by Buddhadatta Thera, London: Pali Text Society. 
Hultzsch, E. (1925) Corpus Inscriptionum Indicarum, Vol. 1, Inscriptions of Ásoka, new edn, Oxford: Clarendon Press.

İsādidásopaniṣadạ̣ (1978) Ten Principal Upanshads with Śāikarabhāṣya, Delhi.

Jacobi, H. (trans.) (1964) Jain Sūtras, Delhi.

Jaini, P.S. (1980) 'Karma and the Problem of Rebirth in Jainism', in Doniger O'Flaherty, W. (ed.), Karma and the Problem of Rebirth in Classical Indian Traditions, Berkeley, CA: University of California Press.

Jaini, P.S. (1980-1). 'The Buddhist and Jaina concepts of man and society as revealed in their religious literature', Sambodhi, 9 (1-4): 40-51.

Jaini, P.S. (1990) The Jaina Path of Purification, Delhi: Motilal Banarsidass.

James, W. (1961) The Varieties of Religious Experience, New York: Simon and Schuster.

Jayawickrama, N. A. (ed.) (1962) Samantapāsādikā, Vol. 1, The Inception of Discipline and the Vinaya Nidāna, London: Pali Text Society.

Jayawickrama, N. A. (ed.) (1971) Thüpavamsa. The Chronicle of the Thüpa and the Thüpavamsa, London: Pali Text Society.

Jennings, J. G. (1947) The Vedāntic Buddhism of the Buddha, London.

Johnson, W. J. (1995) Harmless Souls, Delhi: Motilal Banarsidass.

Johnston, E. H. (ed.) (1935-6) The Buddhacarita or the acts of the Buddha, Calcutta: Baptist Mission Press.

Kane, P. V. (1974) History of Dharmásāstra, Vol. 2, Poona: Bhandarkar Oriental Research Institute.

Kapila, M. (1940) Patanjala Darshana of the System of Yoga Philosophy (ed. P. J.Vidyasagara; with the commentary of Vyasa and the gloss of Vachaspati Mishra), Calcutta.

Kulke, H. (1991). 'Some considerations on the significance of Buddha's date for the history of north India', Symposien zur Buddhismusforschung IV, Vol. 1 (ed. H. Bechert), Göttingen: Vandenhoeck \& Ruprecht.

Laidlaw, J. (1995) Riches and Renunciation, Oxford: Oxford University Press.

Lamotte, É. (1980) Le Traité de la Grande Vertu de Sagesse, Vol. V, Louvain la Neuve: Université de Louvain.

Lamotte, É. (1988) History of Indian Buddhism (English trans. S. WebbBoin), Louvain la Neuve: Université de Louvain.

Lath, M. (1991) 'Somadeva Suri and the question of Jain identity', in Carrithers, M. and Humphrey, C. (eds), The Assembly of Listeners. Jains in Society, Cambridge: Cambridge Univesity Press, pp. 19-39.

Ling, T. O. (1962) Buddhism and the Mythology of Evil, London: Allen \& Unwin.

Lofland, J. (1966) Doomsday Cult, Englewood Cliffs, NY: Prentice-Hall. 
MacQueen, G. (1988) A Study of the Śrāmanyaphalasūtra, Wiesbaden.

Manné, J. (1991) 'Categories of sutta in the Pāli Nikāyas and their implications for our appreciation of the Buddhist teaching and literature', Journal of Pali Text Society, XV: 73.

Masefield, P. (1980) Dhammapāla. Elucidation of the Intrinsic Meaning So Named the Commentary on the Peta-Stories (trans. U Ba Kyaw), London: Pali Text Society.

Masson, J. L. and Patwardhan, M. V. (1970) Aesthetic Rapture. The Rasadhaya of the Nātyásāstra, Poona: Deccan College.

Mauss, M. (1993) The Gift (trans. W. D. Halls), London: Routledge.

Michaels, A. (1997) 'Gift and return gift, greeting and return greeting in India. On a consequential footnote by Marcel Mauss', Numen, 44.

Misra, G. S. P. (1972) The Age of Vinaya, New Delhi: Munshiram Manoharlal.

Morris, B. (1994) Anthropologival Studies of Religion, Cambridge: Cambridge University Press.

Morris, R. (ed.) (1882) Buddhavamsa and the Caryā Piṭaka, London: Pali Text Society.

Mylius, K. (1988) Geschichte der altindischen Literatur, Bern.

Ñānamoli, B. (trans.) (1964) The Path of Purification, Colombo.

Ñānamoli, B. and Bodhi B. (1995) The Middle Length Discourses of the Buddha. A New Translation of the Majjhima Nikāya, Boston.

Narain, A. K. (ed.) (1979) Studies in Pāli and Buddhism. A Memorial Volume in Honor of Bhikkhu Jagdish Kashyap, Delhi.

Norman, K. R. (1991) 'The role of the layman according to the Jain canon', in Carrithers, M. and Humphrey, C. (eds), The Assembly of Listeners. Jains in Society, Cambridge, pp. 31-39.

Oldenberg, H. (1879) Dīpavamsa, London: Pali Text Society.

Oldenberg, H. (trans.) (1879-83) Vinaya Pitakam, Vols 1-5, London: Pali Text Society.

Oldenberg, H. (1894) Die Religion des Veda, Berlin.

Oldenberg, H. and Pischel, R. (eds) (1966) Theragāthā and Therīgāthā, London: Pali Text Society.

Olivelle, P. (trans.) (1996) Upaniṣads, Oxford and New York: Oxford University Press.

Osarchuk, M. and Tatz, S. J. (1973) 'Effect of induced fear of death on belief in afterlife', Journal of Personality and Social Psychology, 27: 256-60.

Pachow, W. (1955) A Comparative Study of the Pratimoksa, Santiniketan Press: Santiniketan, India.

Pals, D. L. (1987) 'Is religion a sui generis phenomenon?', Journal of the American Academy of Religion, 55 (2): 259-82.

Pals, D. L. (1990). 'Autonomy, legitimacy and the study of religion', Religion, 20: 1-16. 
Panglung, J. L. (1981) Die Erzählstoffe des Mūlasarvāstivāda-Vinaya Analyziert auf Grund der Tibetischen Übersetzung, Tokyo.

Paranavitana, S. (1970) Archaeological Survey of Ceylon, Vol. 1, Inscriptions of Ceylon, Ceylon.

Parry, J. (1986) 'The gift, the Indian gift and the "Indian gift" , Man: The Journal of the Royal Anthropological Institute, 21.

Parry, J. J. (1994) Death in Banaras, Cambridge: Cambridge University Press.

Penner, H. H. and Yonan E. A. (1972) 'Is a science of religion possible?' The Journal of Religion, 52: 107-33.

Pervin, L. A. (1993) Personality. Theory and Research, New York.

Poussin, L. de La Vallée (Trans.) (1971-80) L'Abhidharmakósa de Vasubandhu, 6 vols. Brussels: Institute des hautes Etudes Chinoises (English trans. L. M. Pruden).

Prebish, C. (1979) 'Recent progress in Vinaya studies', in Narain, A. K. (ed.), Studies in Pāli and Buddhism. A Memorial Volume in Honor of Bhikkhu Jagdish Kashyap, Delhi.

Prebish, C. (1994). A Survey of Vinaya Literature, Taipei: Jin Luen Publishing House (The Dharma Lamp Series).

Preus, J. S. (1987) Explaining Religion. Criticism and Theory from Bodin to Freud. New Haven, CT: Yale University Press.

Qvarnström, O. (1989) Hindu Philosophy in Buddhist Perspective. The Vedāntatattvaviniśsaya Chapter of Bhavya's Madhyamakahrdayakārikā, Lund.

Radhakrishnan, S. (ed.) (1992) Dhammapada, Oxford: Oxford University Press.

Raheja, G. G. (1988) The Poison in the Gift, Chicago: Chicago University Press.

Rahula, W. (1966) History of Buddhism in Ceylon. The Anurādhapura Period, Colombo.

Reynell, J. (1985) 'Renunciation and ostentation', Cambridge Anthropology, 9 (3): 20-33.

Rhys Davids, C. A. F. (ed.) (1921) The Visuddhimagga of Buddhaghosa, London: Pali Text Society.

Rhys Davids, Mrs (trans.) (1913) Theragāthā, London: Pali Text Society. Rhys Davids, T. W. (1925) The Questions of King Milinda, London: Pali Text Society.

Rhys Davids, Mrs (trans.) (1932) Therīgāthā, London: Pali Text Society. Rhys Davids, Mrs (trans.) (1950-6) Samyutta Nikāya, Vols I-II, London: Pali Text Society.

Rhys Davids, T. W. (trans.) (1977) Dīgha Nikāya, London: Pali Text Society.

Rhys Davids, T. W. (trans.) (1977) Dialogues of the Buddha [Dīgha Nikāya], London: Pali Text Society. 
Rhys Davids, T. W. and Carpenter, E. (eds) (1947-9) Dīgha Nikāya, London: Pali Text Society.

Richardson, J. T. (1989) 'The psychology of induction: A review and interpretation', In Galanter, M. (ed.), Cults and New Religious Movements, Washington, DC.

Ross, L. and Nisbett, R. E. (1991) The Person and the Situation. Perspectives of Social Psychology, New York: McGraw Hill.

Rothbaum, F., Weisz, J. R. and Snyder, S. S. (1982) 'Changing the world and changing the self: A two-process model of percieved control', Journal of Personality and Social Psychology, 42: 5-37.

Śāntideva [1957] Śikșā Samuccaya (ed. C. Bendall), The Hague.

Śāntideva [1990] Śikṣā Samuccaya (trans. C. Bendall and W. H. D. Rouse), Delhi (1st edn 1922).

Śāntideva [1996] The Bodhicaryāvatāra (trans. K. Crosby and A. Skilton), Oxford: Oxford University Press.

Schlingloff, D. (1963) 'Zur Interpretation des Prātimokṣasūtra', Zeitschrift Der Morgenländischen Gessellschaft, 113.

Schmithausen, L. (1992) 'An attempt to estimate the distance in time between Aśsoka and the Buddha in terms of doctrinal history', Symposien zur Buddhismusforschung IV, Vol. 2 (ed. H. Bechert), Göttingen: Vandenhoeck \& Ruprecht.

Schmithausen, L. (1997) Maitri and Magic: Aspects of the Buddhist Attitude toward the Dangerous in Nature, Vienna.

Schopen, G. (1997) Bones, Stones and Buddhist Monks. Collected Papers on the Archaeology, Epigraphy and Texts of Monastic Buddhism in India. Honolulu: University of Hawai'i Press.

Schubring, W. (1962) The Doctrine of the Jains, Delhi: Motilal Banarsidass.

Segal, R. A. (1983) 'In defence of reductionism', Journal of the American Academy of Religion, 51 (1): 97-124.

Segal, R. A. and Wiebe, D. (1989) 'Axioms and dogmas in the study of religion', Journal of the American Academy of Religion, 57 (3): 591605.

Shri Acharya Kunda Kunda (1990) Samayasara (trans. J. L. Jain), Delhi. von Simson, G. (ed.) (1986) Prātimokșasūtra der Sarvāstivādins, Göttingen: Vandenhoek \& Ruprecht.

von Simson, G. (1991) 'Der zeitgeschichtliche Hintergrund der Entstehung des Buddhismus und seine Bedeutung fur die Datierungsfrage', Symposien zur Buddhismusforschung IV, Vol. 1 (ed. H. Bechert), Göttingen: Vandenhoeck \& Ruprecht.

Skilling, P. (ed.) (1994) Mahāsūtras: Great Discourses of the Buddha, Vol. 1, Oxford: Pali Text Society.

Skilling, P. (ed.) (1997) Mahāsūtras: Great Discourses of the Buddha, Vol. 2, Oxford: Pali Text Society. 
Spiro, M. E. (1982) Buddhism and Society. A Great Tradition and its Burmese Vicissitudes, Berkeley, CA: California University Press.

Sprockhoff, J. D. (1994) 'Zur 'Weihe' des Asketen', Wiener Zeitschrift für die Kunde Südasiens, 38: 61-83.

Thapar, R. (1984) From Lineage to State. Social Formations in the MidFirst Millennium $B C$ in the Ganga Valley, Bombay: Oxford University Press.

Thorson, J. A. and Powell, F. C. (1990) 'Meanings of death and intrinsic religiosity', Journal of Clinical Psychology 46 (4): 379-91.

Trenckner, V. (ed.) (1948) Majjhima Nikāya, Oxford: Pali Text Society.

Trenckner, V. (ed.) (1962) The Milindapañho, London: Pali Text Society.

Trautmann, T. R. (1981) Dravidian Kinship, Cambridge.

Waldschmidt, E. (1952) Das Catușpariṣatsūtra [Catuṣparișatsūtra], Eine kanonische Lehrschrift über die Begründung der buddhistischen Gemeinde. Text in Sanskrit und Tibetisch, verglichen mit dem Pāli nebst einer Übersetzung der Chinesischen Entsprechung im Vinaya der Mūlasarvāstivādins, Berlin.

Waldschmidt, E. (1967). 'Vergleichende Analyse des Catuṣpariṣatsūtra', in Von Ceylon bis Turfan. Schriften zur Geschichte, Literatur, Religion und Kunst des indischen Kulturraumes, Göttingen.

Warder, A. K. (1956) 'On the relationship between early Buddhism and other contemporary systems', The Bulletin of the School of Oriental and African Studies, 18: 43-63.

Weerasinghe, H. (1997) 'Fear: A Buddhist interpretation', in Dhammajoti, K. L., Tilakaratne, A. and Abhayawansa, K. (eds), Recent Researches in Buddhist Studies. Essays in Honour of Professor Y. Karunadasa, Colombo.

Wiebe, D. (1984) 'Beyond the sceptic and devotee: Reductionism in the scientific study of religion' Journal of the American Academy of Religion, 52 (1): 157-65.

Wijayaratna, M. (1990) Buddhist Monastic Life (trans. C. Grangier and S. Collins), Cambridge: Cambridge University Press.

Williams, P. (1994) Mahāyāna Buddhism, London and New York: Routledge.

Williams, R. (1983) Jain Yoga. A Survey of the Medieval śrāvakācāras, Delhi: Motilala Banarsidass.

Wilson, B. (1963) 'The typology of sects' (trans. J. M. Robertson), Archives de Sociologie de Religion, 16: 49-63.

Wilson, B. R. (1970) Religious Sects. A Sociological Study, London.

Wilson, B. R. (1982) Religion in Sociological Perspective, New York: Oxford University Press.

Wilson, E. O. (1975) Sociobiology. The New Synthesis. Cambridge, MA: Harvard University Press. 


\section{BIBLIOGRAPHY}

Wilson, E. O. (1978) On Human Nature. Cambridge, MA: Harvard University Press.

Windisch, E. (1948) Itivuttaka, London.

Woods, J. H. (1914) The Yoga System of Patañjali, Cambridge, MA.

Woodward, F. L. (1935) The Minor Anthologies of the Pali Canon, Part II, London.

Woodward, F. L. (trans.) (1950-6) Samyutta Nikāya, Vols III-V, London.

Woodward, F. L. (1952) The Book of the Gradual Sayings, Vol. II, London.

Woodward, F. L. (1956) The Kindred Sayings, Part V, London: Luzac \& Co.

Yinger, M. (1971) The Scientific Study of Religion, London: Routledge. 


\section{INDEX}

ahimsā 109, 112

Ajātaśatru 39, 64-6, 88

Ajita Kesakambalī 28

Allport, Gordon 22, 25

Ānanda 15, 16, 19, 38, 40, 106

Anāthapiṇụika 37, 40

Anumodana and the idea of merittransference 105

Anuśsāsanaparvan 99, 106, 110, 113-14

Aśoka 6, 7, 12, 13, 17, 114-15; blends sacrifice and charity 114; date in relation to the date of the Buddha 12; his missions and the origins of Buddhist schools 6

Bareau, André 9, 13, 14, 16

Basham, A. L. 28

Bechert, Heinz 12, 13, 16, 17

Bhīṣma 110, 113

Bhagavdḡitā 9, 115

Bimbisāra 23, 27, 30

Brahmins 26, 28, 97, 102, 104, $112,114,118$

Buddha 1-3, 5, 7-9, 11-13, 1519, 23, 25-45, 46, 50-4, 59, $60,62-6,73-7,81,82,84,87-$ $90,100,102,106,107,112$, 116; asks monks to go on missions 31; biographical information of the Skandhaka 11; competing with other sect leaders 29; $400 \mathrm{AD}$ as probable date of his death 13; his fear and renunciation of life as a prince 53 ; his role compared to that of the lion 83; met the authors of the Skandhaka? 17; political situation at the time 59; the problem of dating 13; unwillingness to teach after the enlightenment 26; wants to produce samvega to convert matted hair ascetics 30

Buddhacarita 53, 61-2

Buddhaghosa 53, 78, 83, 90; discusses causes of samvega 84 Buddhism 1-6, 11, 21-4, 27, 28, $30,31,33,43,45,46,50,52$, 53, 55-9, 62, 65, 67, 70, 71, 74, 75, 77, 78, 80-108, 114, 115 ; and changes in the idea of sacrifice 110-15; its ideas of giving compared with Hinduism and Jainism 114-15; orthodox views on karma 104; spread through inherent qualities of teaching 91

Buddhist literature, its Buddhist texts 2, 3, 34, 45, 53, 54, 61, 90, 91, 97, 99, 101; historical value reasessed in light of the date of the Buddha 13

Carrithers, Michael 25

Cārvākas 28

Catuṣparișatsūtra 8, 10, 11, 105 ceto-vimutti 67

Christianity 46, 47, 91 
clothes: the appearance of monks' 39

cognitive dissonance 4, 53, 57 , $58,61-4,67$

conversion $2,26,30,32,45,46$, $48,49,51-5,58,61,66,67$, 88-90; between sects 50-2; Buddhist and Christian ideas compared 46; compared to brainwashing 47; as crosscultural category 55; the passive view of 48; of St Paul 47; without personal crisis or change in beliefs 51

conversionism 21, 22, 26, 31, 34, 45

Cort, John 103

Council of Pātaliputra 14

Council of Vaiśâlì , 12, 14, 15, 16, 17,19

Cullavagga 9, 10, 15, 28, 108

Dìpavamsa 6, 12, 15, 19, 12 debates: typology of 33

determinism, in the study of conversion 48

Devadatta, the evil cousin of the Buddha 39

Dhamma 26, 27, 29, 31, 32, 33, 38,91

Dharmaguptakas 8, 15

dukkha: suffering 66, 84, 90

dwelling places for monks and the beginning of monasticism 41-2

extrinsic motivation 22, 24, 44; among Burmese monks 25; in modern Buddhist societies 25 extrinsic vs. intrinsic motivation 22

fear: as religious motivation $82-8$

Festinger, Leon 58, 61, 66

Fourth Symposium on Buddhist Studies 13

Frauwallner, Erich 5-19, 42

gifts 33, 97-119

Gombrich, Richard F. 14, 60, 67,
$88,105,116$

Hemacandra 103, 108, 112, 117

Hinduism 87, 109, 115

Horner, I. B. 10, 15, 34, 35

introversionism 21, 22, 26, 34, 44

Jaini, Padmanabh S. 75-6, 105

Jainism and Jaina literature 28, 51, 75-6, 102-4, 107, 108

Jerusalem 47

Jesus 47

Kassapa: the matted hair ascetics $27,28,29,30,67,89$

Khandhaka 1, 5, 8, 10, 21, 26, 99; see also Skandhaka

Khantivādi Jātaka 64-5

Kierkegaard 71, 94-5

Kosambī , 37, 100

Krṣna 115

Lamotte, Étienne 7, 8, 13, 16, 17 , $19,90-1$

MacQueen, Graeme 64, 88

Mahīsāsakas 5, 8

Mahāparinirvānasūutra 11

Mahāsāṃghikas 5, 8, 12, 14

Mahāvamsa 6, 12, 19, 89, 92

Mahāvagga 8-11, 15, 22, 26, 51, $60,88,100$

Mahāvastu 9

Makkhali Gosāla 27, 28

Мапи 104, 109, 112, 113

Mauss, Marcel 98, 106, 112

Mūlasarvāstivādins 5, 6, 7, 8

merit 44, 98-119; transferring of 104-5

Moggallāna 31, 38, 39, 40, 50, 51, 107

motivation: theories of 57

Nigaṇtha Nātaputta 27, 28

Nigrodha 31, 32, 33

Nirvāṇa 11, 12, 13, 14, 15, 16, 17 , 19,102

Oldenberg, Hermann 9, 10, 18, 19 
Pakudha Kaccāyana 27, 28

pañ̃̃a : insight 66-7

pañ̃̃a-vimutti 67

Pauline paradigm 47-8

Petavatthu 103, 107

physical injuries or illness 36

Prebish, Charles 2

psychoanalysis 57

psychological incongruity 4, 57, 58-61

Pāṭaliputra 5, 9, 14

rains: rules for entering upon 42 reductionism 62,68

religion: and the need for control 64; categories for the crosscultural study of 61 ; reductionism and theories about 68; the origins of religions and the religious motivation of individuals 57; provides a link between subjective and objective reality 58 ;

religious transformation: three elements of $60-1$

Richardson, J. T. 48, 49

rules for admission as expression of growing introversionism 34

Rājagaha 23, 28, 31, 40, 42

Samgha 2, 3, 5, 8, 9, 10, 11, 12, $17,19,21-7,34-8,41-5,50-$ 2, 57, 59, 72, 73, 96, 98, 100, 102, 105, 107, 109, 117, 119; different reasons for joining 24 ; as field of merit 107 ; growing organization 35 ; necessity of keeping the wrong people out 26; people joining to escape military service etc. 23; reasons for joining according to B. G. Gokhale 54 samvega 30, 52, 53, 60-2, 76, 81, $82-7,88,89$; compared to cognitive dissonance 61-2; etymology of the word 61-2

Sañjaya Belatthiputta 27, 28 Śanjkara 79
Sāriputta 31, 39, 40, 50, 51, 72, 81

Sarvāstivādins 5, 6, 7, 8, 83

Sāvatthi 37, 40

Schlingloff, Dieter 10

Schopen, Gregory 99

secondary control: types of 66

sects: typology of 22

Simson, Georg von 14

Skandhaka 1, 5, 7-14, 17, 18, 19, 34; comparison between different schools 5; composition of the oldest work 12; date of composition in relation to the date of the Buddha 12; dating by Frauwallner refuted 17; defintion of the term 5 social psychology 1, 2, 3, 45, 49, 56

sociobiology 48,49

sociology of knowledge 58

Spiro, Melford 25, 100, 110

Śrāmanyaphalasūtra 52, 64-5

śrāvakācāra 103

Sri Lanka 24, 33, 76, 89

St Augustine 47

St Paul 47

Thailand 25

Therī $g \bar{a} t h \bar{a} 23,24$

Theragāthā 15, 23, 59, 77

Theravāda Buddhism 25, 43, 44, 99, 104, 107, 116

Trautmann, Thomas 111

Tripusa and Bhallika: first lay followers 105

UFO cult: compared to Buddhism 51

unity of the Samgha as expression of purity 37

Upanișads 78-9, 111; and changes in the idea of sacrifice 110-11

Vedic sacrifices 110-11

Vibhañga $9,10,19$

Vinaya $5,6,7,8,11,12,15,18$, 


\section{INDEX}

19, 21, 22, 26, 28, 31, 34, 39, Williams, R. 101-2, 108

$40,41,60,89,99-100$;

Wilson, Bryan 21, 22, 26, 34; his

comparison between different schools 5 definition and typology of sects 22

Vinaya of Kaśmīr 6

Vinaya of Mathurā 6, 7

Yasa 15, 16, 26, 27

Yinger, Milton 62

Warder, A. K. 24

Yudhisthira 110, 113 